\title{
The Triassic rocks, with particular reference to predicted and observed performance of some major foundations
}

\author{
A. C. MEIGH, OBE, DSc(Eng), FICE, FGS*
}

\begin{abstract}
An outline of the geology of the Trias in the British Isles is given, together with a description of its depositional environment. The lithology is described and attention is drawn to differences to be expected between materials in basins, shelf areas between basins, and marginal zones. Faulting, weathering and alteration by leaching are discussed. Variation of the Triassic rocks with depth and from place to place is examined in terms of the drained modulus of elasticity, $E$. For a number of sites, depth profiles of modulus, and other data, are presented; these are related to lithology and weathering which are related in turn to the geology. $E$ values were obtained from laboratory tests, field tests and by back-analysis of observed settlements. In this connexion a settlement calculation procedure is presented. Three major case histories are described: Heysham, where calculated and observed settlements are in agreement; Oldbury, where the observed settlement greatly exceeded that calculated, and Cardiff, where it was considerably less. Possible explanations of the differences are discussed, based for Oldbury on the results of the subsequent B Station investigation, and for Cardiff on a programme of investigation in a nearby quarry. Suggestions are made concerning drilling methods and investigation procedures.
\end{abstract}

Une esquisse de la géologie du Trias dans les Îles Britanniques est exposée ainsi qu'une description des alentours de son gisement. La lithologie est décrite et l'attention est attirée sur les différences auxquelles on peut s'attendre entre les faciés dans les bassins, dans les seuils entre bassins, et dans les zones marginales. La tectonique et l'altération par les agents atmosphériques et par l'eau sont examinées. La variation des roches du Trias avec la profondeur et le lieu est examinée et traduite à l'aide du module d'élasticité (E) drainé. Pour un certain nombre de sites, les profils en profondeur des modules, ainsi que d'autres données sont présentés; ceux-ci sont reliés à la lithologie et à l'altération qui à leur tour dépendent de la géologic. Les valeurs de $E$ ont été obtenues par des essais de laboratoire, des essais in situ et par déduction de tassements observés. A cet égard une méthode d'évaluation des tassements est présentée. Trois exemples principaux sont décrits: Heysham, où les tassements calculés et enregistrés sont en concordance; Oldbury, où le tassement observé dépasse grandement celui calculé; et Cardiff, où il était considérablement inférieur. Des explications possibles des différences sont présentées, dans le cas de Oldbury elles sont basées sur les résultats de la campagne de reconnaissance complémentaire de la Station $\mathbf{B}$, et pour Cardiff, sur une reconnaissance effectuée dans une carrière proche. Des suggestions sont faites, concernant les méthodes de sondage et les méthodes d'investigation.

In preparing this lecture I started out to answer the question "how do the engineering properties of the Triassic rocks vary from one place to another, and how does the variation relate to the geology?' But engineering problems in the Triassic rocks (and in other rocks for that matter) require knowledge of many properties, such as strength, deformation characteristics, permeability and response to mechanical disturbance. Much as I would have liked to have discussed all of these, I have been forced to be selective, in order to consider, in the span of one lecture, the Trias in the UK over as wide an area as possible.

I have therefore concentrated on deformation characteristics, more particularly response to vertical loading, and have looked at this in terms of drained modulus of elasticity, $E$. Data on this have been obtained from laboratory tests, field tests and analysis of case histories. I have examined variation of $E$ with depth, and variation from site to site. I have tried to relate that variation to lithology and weathering, and to relate these in turn to broad geological structure, i.e. to the palaeogeography. I believe that case histories are important, and in support of this,

Discussion on this paper closes 1 December, 1976. For further details see page 549.

* Managing Director, Soil Mechanics Limited. 
I quote Terzaghi's (1948) foreword to the first issue of Géotechnique. He said 'During the last decade, theory and the techniques of sampling and testing have advanced far beyond immediate practical needs, whereas our knowledge of the difference between the behaviour of soils in the field and in the laboratory has lagged behind. Therefore, at the present time, a well-documented case history should be given as much weight as ten ingenious theories and the results of laboratory investigations should not receive too much attention unless the validity of the conclusions has been demonstrated by adequate field observations on full-sized structures.'

In the latter part of the lecture, three major case histories are described, in all of which investigations have been undertaken and settlements measured. One was straightforward; the other two were difficult, and I shall try to explain the nature of the difficulties and how I think some of them could be overcome. I will also suggest a rider to Terzaghi's statement.

\section{THE TRIAS}

\section{General}

The beginning of the Triassic period was also the beginning of the Mesozoic era. It was preceded by the Permian period of the Upper Palaeozoic era, and followed by the Jurassic and Cretaceous periods of the Mesozoic. The Triassic period began some 225 million years ago and lasted about 50 million years. It took its name from the threefold division of the period in Germany into the Buntsandstein (mottled sandstone), the Muschelkalk for which there is no lithostratigraphical equivalent in this country, and the Keuper. The outcrop of the Trias in the British Isles is shown in Fig. 1.

The Institute of Geological Sciences has recently adopted a revised Triassic nomenclature within the United Kingdom. ${ }^{1}$ Table 1 shows the new group names for onshore work alongside the traditional Triassic nomenclature for the British Midlands. It appears that another nomenclature, bearing different names though similar broad groupings, has been adopted by a joint oil industry-IGS committee, for southern North Sea use (Rhys, 1974). I shall however adhere to the traditional nomenclature.

\section{Depositional environment}

To understand the Triassic environment we must look back into the Permian period. During the Permian, the Zechstein Sea stretched across the North Sea and covered much of northern Europe. An arm spread across northern England into Ulster. To the south of this

Table 1. Triassic stratigraphy, Midland area

\begin{tabular}{|c|c|c|}
\hline Traditional nomenclature & & Revised nomenclature \\
\hline Rhaetic Beds & & Penarth group \\
\hline $\begin{array}{l}\text { Tea Green Marls } \\
\text { Upper part of Keuper Marl } \\
\text { Lower part of Keuper Marl } \\
\text { Waterstones }\end{array}$ & Keuper (group) & Mercia Mudstone group \\
\hline Keuper Sandstone & & \\
\hline $\begin{array}{l}\text { Upper Mottled Sandstone } \\
\text { Bunter Pebble Beds }\end{array}$ & Bunter (group) & Sherwood Sandstone group \\
\hline
\end{tabular}

Note: Revised formation nomenclature has been omitted.

${ }^{1}$ No formal statement has been made by IGS, but the revised nomenclature has been introduced on Sheet No. 66 , Blackpool. 


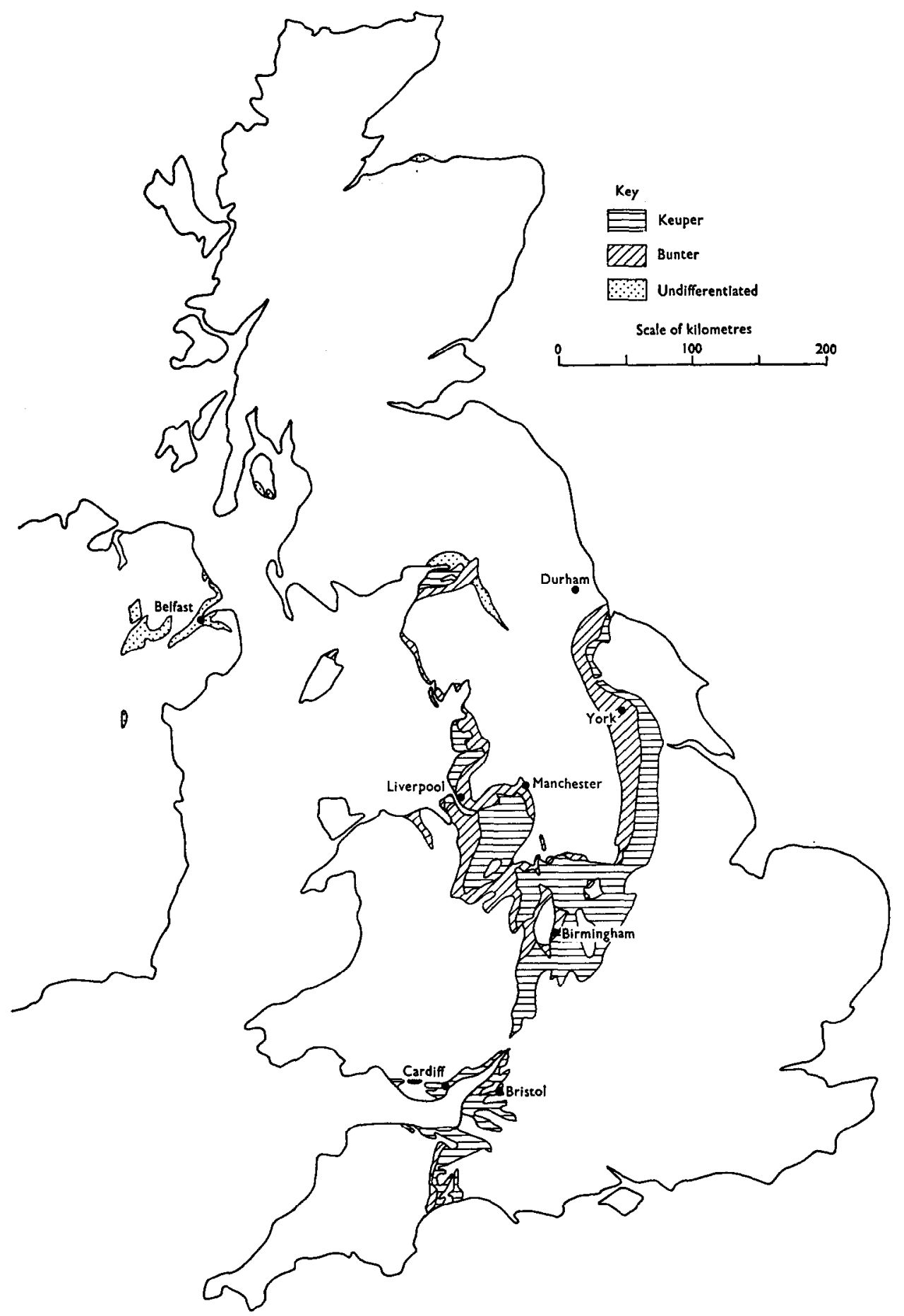

Fig. 1. Triassic outcrops of the British Islands (omitting drift). Based on IGS 25 miles to one inch map 
sea, large valleys and desert plains in the uplands created by Variscan folding became covered by considerable thicknesses of wind-blown sand (up to $300 \mathrm{~m}$ ) which subsequently formed red sandstones. At the same time, closed basins formed in fault-controlled troughs (or grabens) both in upland areas and in areas previously occupied by the retreating Zechstein Sea. Continuing subsidence in these basins led to the accumulation of thick deposits which continued into Triassic time. The environment was continental and extremely arid.

By the beginning of the Triassic period the Zechstein Sea had retreated to the North Sea area as a result of one of several marked fluctuations in global sea levels which occurred during the Permo-Trias, and isolated basins formed a series of playas (or salt pans) bordered by piedmont fans, fed by torrential rivers draining the uplands. Although the climate in the early part of the Triassic period was still arid, the evidence points towards there being water entering the basins from both short-term floods and perennial streams, indicating significant rainfall at least in the upland areas. The evidence indicates that a major river flowing northwards along the Worcester Graben was responsible for most of the Bunter deposits now recognized in the Midlands. The graben can be seen in Fig. 2, drawn to represent a later period in the Trias. This river, with its headwater far to the south and an additional catchment in the Welsh Uplands and East Anglian-Brabant Massif, probably derived considerable quantities of material from the Permian desert deposits and redeposited this, mainly as water-laid (often deltaic) sands, forming the Upper Mottled Bunter and succeeding Keuper Sandstones. This would account for the resemblance of Triassic to Permian sandstones with the important distinction that the Permian is dominantly aeolian and the Bunter and Keuper fluvial or deltaic.

The final stages of deposition of the Bunter Sandstone were followed by relatively minor marine incursions extending into the Cheshire Basin (from the Irish Sea) and the Midlands (from the southern North Sea). At about the same time a tectonic pulse, known as the Hardegsen in the North Sea basin, resulted in faulting, uplift, and the formation of a marked unconformity which in general terms may be taken as defining the beginning of the Keuper (Ziegler, 1975). Subsidence in existing and new grabens accompanied by the flattening of surface profiles in and around the playas resulted in the deposition of the mudstones (commonly referred to as marls although frequently not sufficiently calcareous to be properly so called) and in the formation of the evaporites which are so common in the lower part of the Keuper Marl. ${ }^{2}$ Local geographic changes and flooding from the distant hills led to the deposition of silts and sands in lakes, giving rise to the thin lenticular siltstones and sandstones called skerries.

In the later stages of Keuper deposition, the landscape was reduced to broad flat plains bounded by gentle uplands with occasional 'island' areas of low hills, notably in the Charnwood Forest area (Fig. 2). Mudstones continued to form over a wide area with localized skerries and occasional evaporite horizons. The Arden Sandstone which occurs at a relatively high level in the Keuper succession would appear to represent a delta formed by the river system of the Worcester Graben, due either to a more pluvial period or changes in base level creating a new drainage pattern. The Triassic period closed with a gradual marine incursion marked initially by deposition of the Tea Green Marls (under reducing conditions) and subsequently by the widespread deposition of the marine Rhaetic Beds.

Figure 3, adapted from Audley-Charles (1970), shows a representative section through the Trias from the Mendips to the Humber, indicating the relationship of the main formations and groups to each other.

2 The salt deposits of the Cheshire, Stafford and Droitwich Basins have been extensively worked by brine pumping. This has led to major subsidence problems, which are not discussed here. 


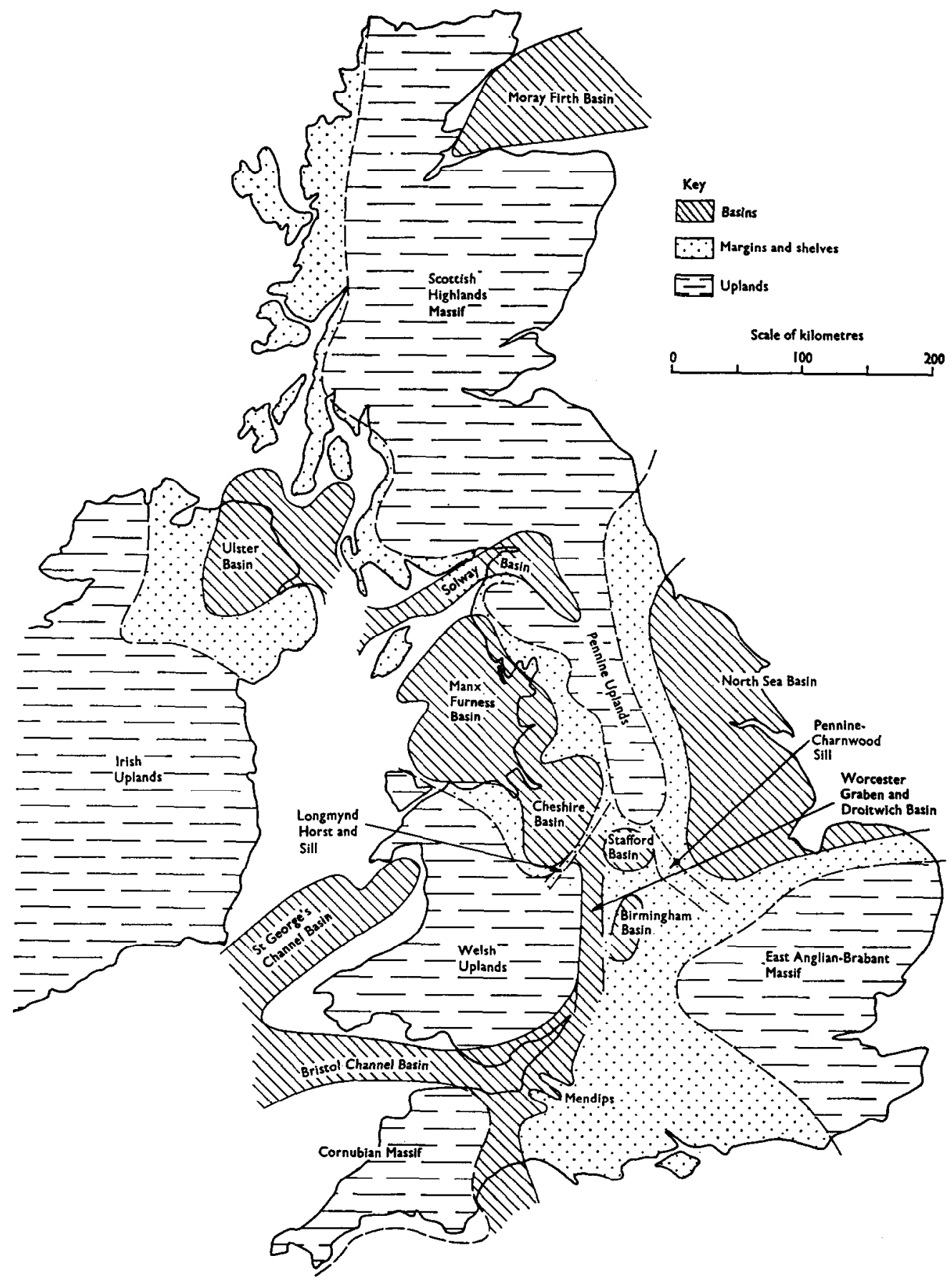

Fig. 2. Main Basins and Uplands in Triassic times (generalized at about the Middle Triassic) 


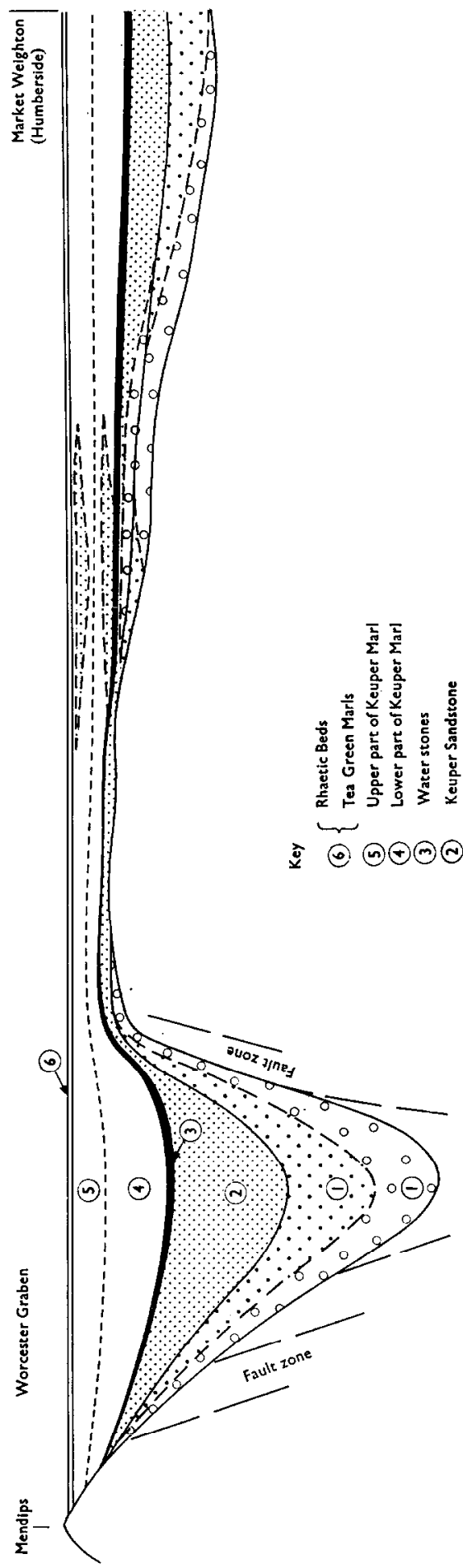

 


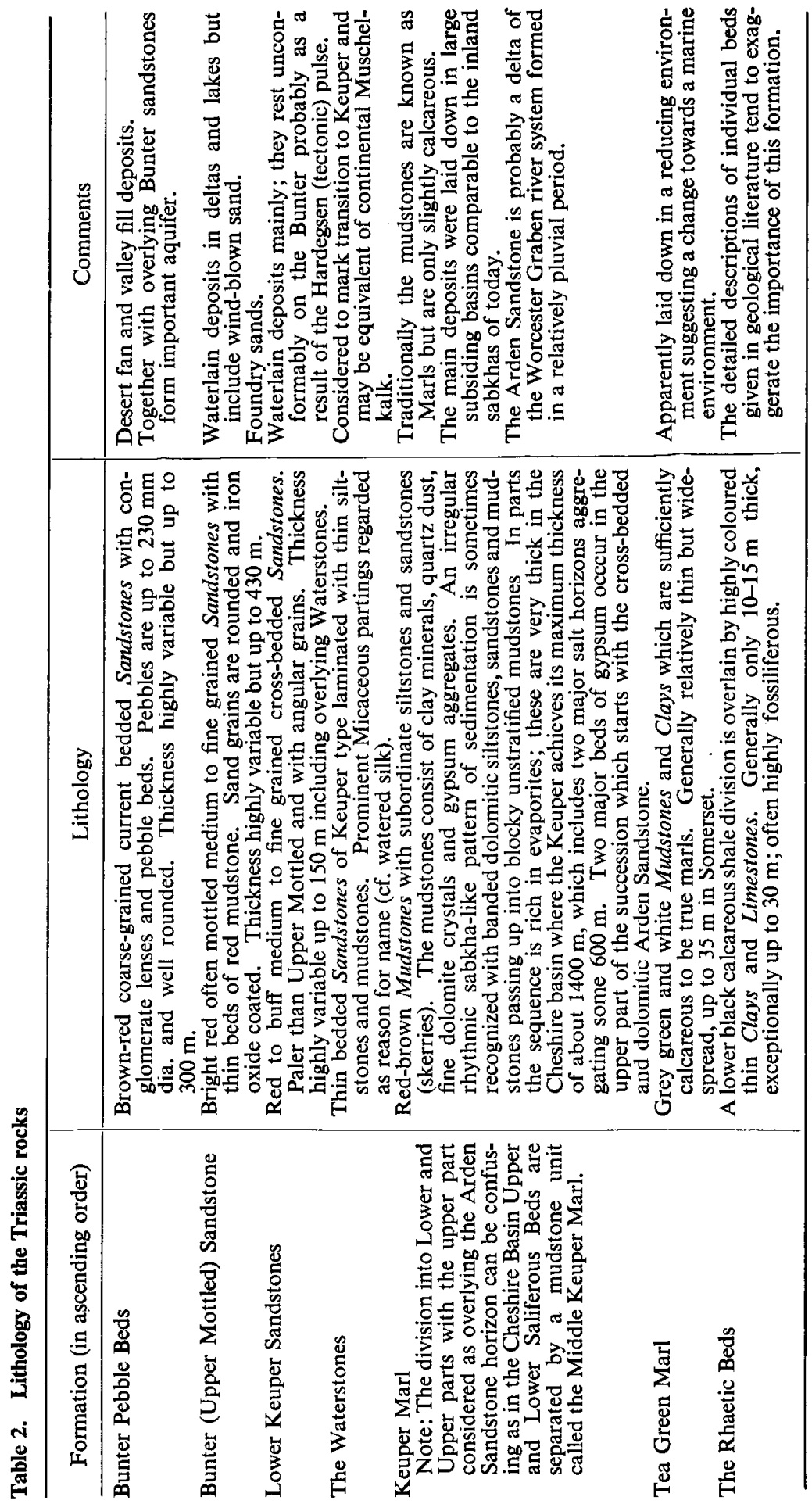


It will be appreciated from the foregoing remarks that the Keuper lithology is complicated by rapid facies changes, particularly along the margins of the basins, and to some extent, on a morc local scale, in the shelf areas. There are then three basic depositional environments:

(a) the basins, where the deposits can be expected to be thick, and in broad terms to be uniform, particularly nearer the centre;

(b) the shelf areas, where the deposits will be thinner and somewhat less uniform, but similar to those in the basins, particularly at upper levels;

(c) the marginal zones, where rapid facies changes must be expected.

\section{Lithology}

Notes on the lithology of the Triassic rocks are given in Table 2.

\section{Faulting and weathering}

The margins of the basins are often fault-controlled. Block faulting is generally quite common in the Trias, some faults persisting over long distances and involving considerable displacement. Generally this faulting has not been accompanied by intense deformation of the adjacent rock masses and does not appear to have significantly affected the intrinsic strength or deformation characteristics.

Weathering of the Bunter and Keuper sandstones and the more arenaceous (coarser) siltstones results largely in the destruction of the cementing material. The sandstone is reduced to a sand, usually with a gradational profile into unweathered rock. Typical is the 'roach', the weathered zone of the Bunter sandstone in north-west England.

The blocky and relatively homogeneous mudstones on exposure to weathering acquire a profile grading downwards from rock completely weathered to a clay near the surface to unaltered rock at depth. Another form of deep weathering or alteration, results from groundwater movements especially under interglacial or periglacial conditions towards deepened glacial valleys when sea levels and local water levels were low. One result of this is the development of leached profiles as described herein. Where this condition has existed there is a strong possibility of selective degradation in layered deposits.

\section{CALCULATION AND ANALYSIS OF SETTLEMENT}

Where the drained modulus of elasticity $E$ is constant with depth and the thickness of the compressible layer is very large compared with the diameter of the circular foundation on its surface, the rigid plate formula may be used to calculate settlement.

$$
S=\frac{\pi}{4} q \frac{B}{E}\left(1-v^{2}\right)
$$

In the Triassic rocks, however, the modulus profile is non-homogeneous the modulus $E$ often increasing approximately linearly with depth, and the rigid plate formula is inappropriate. Using the notation shown in Fig. 4, the modulus may be assumed to vary from some value $E_{0}$ at the rock surface increasing at a rate $K_{z}$ per unit depth, such that the modulus at depth $Z$ below the surface, $E_{z}$, is given by

$$
E_{z}=E_{0}+K_{z} Z
$$

The surface displacement, $s$, beneath the corner of a rectangular area of sides $L$ and $B$, loaded to a uniform stress $q$, resting on a finite compressible layer of thickness $D$, was first derived by 


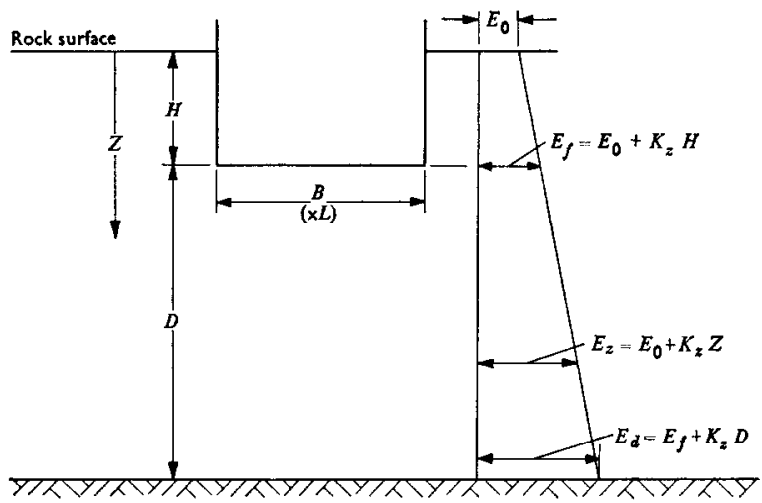

Fig. 4. Notation

Steinbrenner (1934). This approximate solution relates to the case of an elastic homogeneous layer, and was first made widely available by Terzaghi (1943). The solution is of the form

$$
s=q \frac{B}{E} I_{\mathrm{s}}
$$

in which $I_{\mathrm{s}}$ is a displacement influence factor depending both on the geometry of the loaded area, i.e. $D / B$ and $L / B$, and on Poisson's ratio.

For the more practical case in which the compressible layer is non-homogeneous an approximate solution was first presented by Butler (1974) derived by considering a multilayered system in which the modulus $E$ varies for each sub-layer. Butler's adaption of Steinbrenner's solution was for the cases of $\nu=0.1$ and 0.5 only, and for the geometries of $L / B=1,2$ and 5 over the depth range $0<D / B<9$. Using the same computational procedure as Butler, the analysis has been repeated for a more extensive range of values of $L / B$ and $D / B$. Since the value of Poisson's ratio, $\nu$, for Triassic rocks generally falls between about $0 \cdot 10$ and $0 \cdot 30$, for the present review an average value of $0 \cdot 2$ has been used. This would appear to represent all cases to a reasonable degree of accuracy. The results are presented in Fig. 5 as the displacement influence factor $I_{\mathrm{k}}$ against depth factor $D / B$ for varying ratios of $L / B$ and a range of nonhomogeneity factors, $K$, where $K$ is a dimensionless factor, as defined by Butler, namely:

$$
E_{\mathrm{d}}=E_{\mathrm{f}}(1+K[D / B])
$$

or

$$
K=\frac{\left(E_{\mathrm{d}}-E_{\mathrm{f}}\right)}{E_{\mathrm{f}}} \frac{B}{D}=K_{2} \frac{B}{E_{\mathrm{f}}} \quad \text {. . . . . . . . . . }
$$

where $E_{\mathrm{f}}$ is the modulus at foundation level, and $E_{\mathrm{d}}$ is the modulus at the base of the supporting layer.

A more exact analysis for a finite layer with uniform modulus has been presented by Ueshita and Meyerhof (1968) in which account is taken of the roughness (adhesive surface) at the base of the finite layer. From this analysis it would appear that for the cases in which $\nu$ is less than 0.4 , Steinbrenner's solution is in error and underestimates the settlement. They suggest that the error in using Steinbrenner's published curves for $I_{s}$ (Terzaghi, 1943) could be approximately corrected by using a modified depth factor equal to $1 \cdot 2 \mathrm{D} / \mathrm{B}$. The present method of 


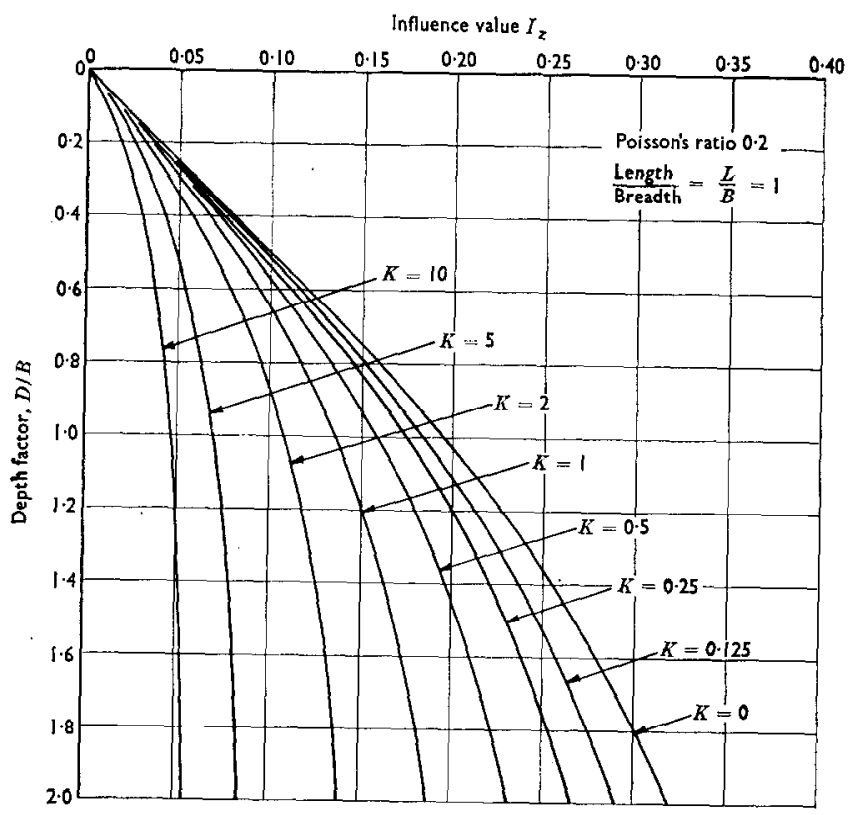

(a)

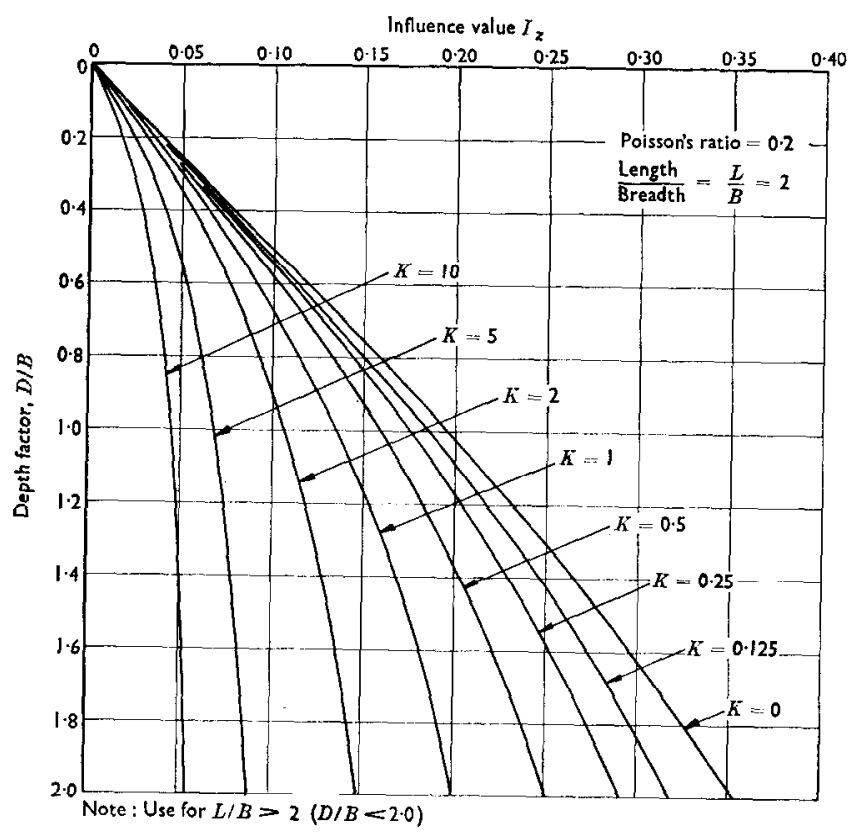

(b)

Fig. 5. Displacement influence factors for non-homogeneous layer 


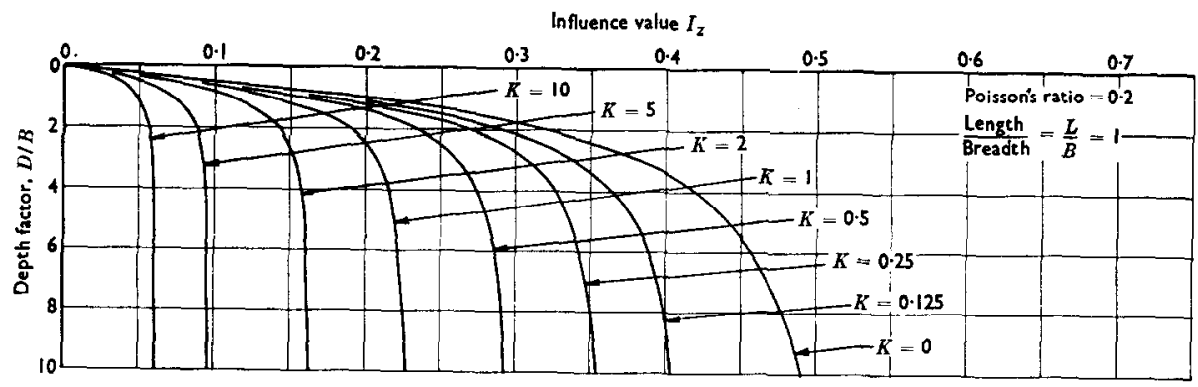

(c)

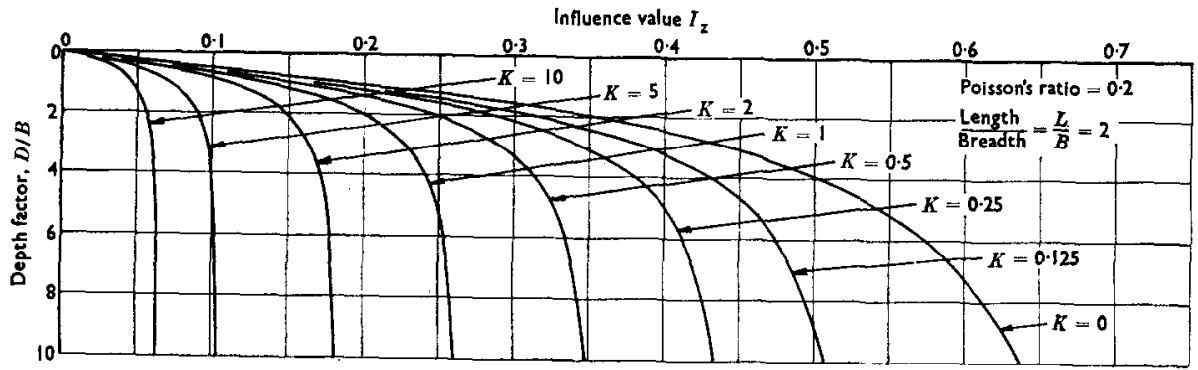

(d)

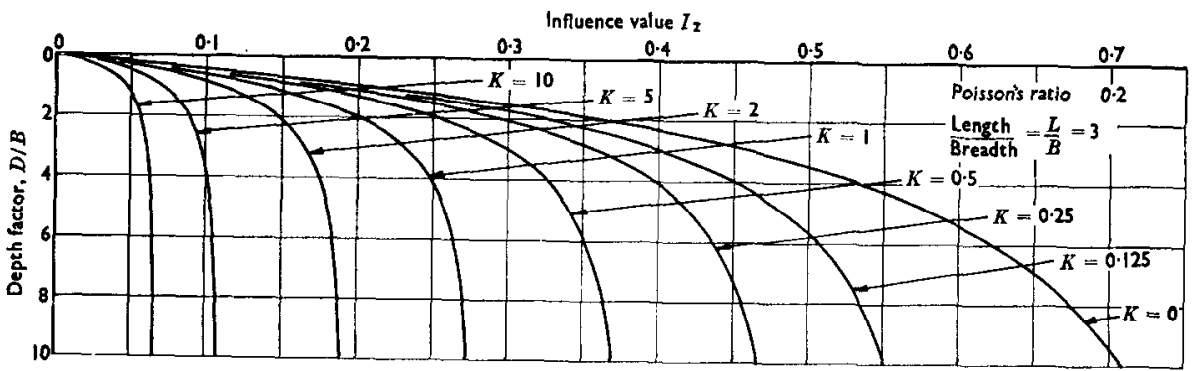

(e)

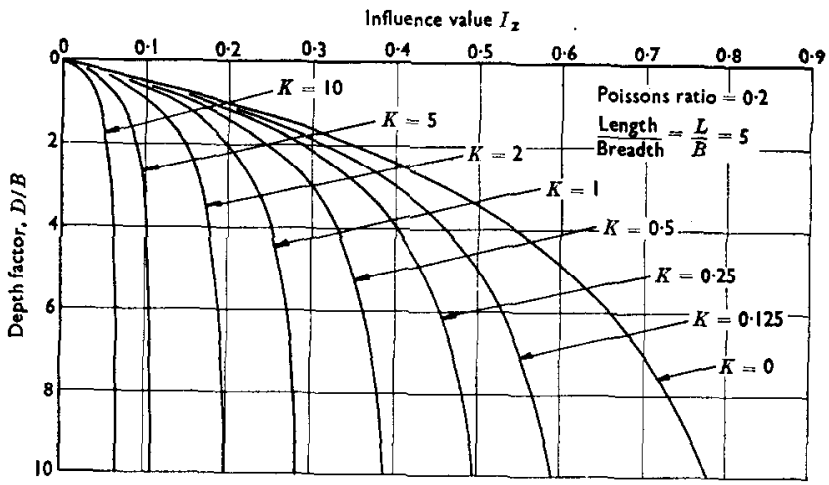

(f) 


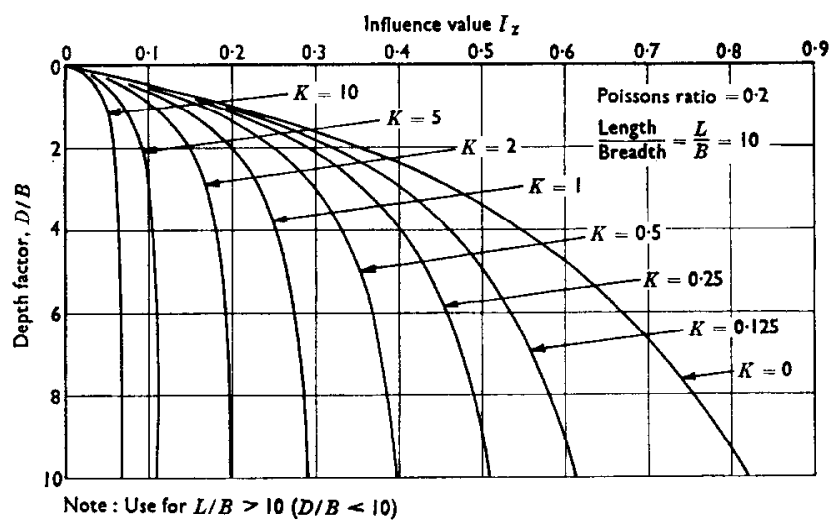

(g)

\begin{tabular}{|c|c|c|c|c|c|c|c|c|c|}
\hline \multicolumn{10}{|c|}{$\begin{array}{l}\text { INFLUENCE FACTORS, IZ, FOR SETTLEMENT AT CORNER OF RECTANGULAR } \\
\text { LOADED AREA ON A NON-HOMOGENEOUS FINITE LAYER }\end{array}$} \\
\hline \multirow{3}{*}{\multicolumn{2}{|c|}{$D / B$}} & \multicolumn{8}{|c|}{ Coefficient of Non-Homogeneity, K, For Poisson's Ratio $v=0.2$} \\
\hline & & $K=0$ & $K=0.125$ & $K=0.25$ & $K=0.5$ & $K=1.0$ & $K=2.0$ & $K=5.0$ & $K=10.0$ \\
\hline & & $I_{z}$ & $I_{z}$ & $I_{z}$ & ${ }^{I} z$ & I $z$ & $I_{z}$ & $I_{z}$ & $1 z$ \\
\hline \multirow{7}{*}{$L / B=1$} & 10 & 0.489 & 0.404 & 0.353 & 0.291 & 0.224 & 0.161 & 0.095 & 0.059 \\
\hline & 20 & 0.514 & 0.413 & 0.359 & 0.294 & 0.226 & 0.162 & 0.095 & 0.059 \\
\hline & 50 & 0.529 & 0.416 & 0.361 & 0.295 & 0.227 & 0.162 & 0.095 & 0.059 \\
\hline & 100 & 0.534 & 0.416 & 0.361 & 0.296 & 0.227 & 0.162 & 0.095 & 0.059 \\
\hline & $\infty$ & 0.539 & & & & & & & \\
\hline & 10 & 0.637 & 0.506 & 0.433 & 0.348 & 0.260 & 0.182 & 0.104 & 0.064 \\
\hline & 20 & 0.686 & 0.524 & 0.444 & 0.354 & 0.264 & 0.184 & 0.104 & 0.064 \\
\hline \multirow[t]{5}{*}{$L / B=2$} & 50 & 0.715 & 0.530 & 0.448 & 0.358 & 0.265 & 0.184 & 0.105 & 0.064 \\
\hline & 100 & 0.725 & 0.531 & 0.448 & 0.356 & 0.265 & 0.184 & 0.107 & 0.064 \\
\hline & $\infty$ & 0.735 & & & & & & & \\
\hline & 10 & $0 . \overline{11}$ & 0.552 & 0.467 & 0.370 & 0.274 & 0.190 & 0.107 & 0.065 \\
\hline & 20 & 0.782 & 0.578 & 0.483 & 0.379 & 0.279 & 0.192 & 0.108 & 0.066 \\
\hline \multirow[t]{5}{*}{$L / B=3$} & 50 & 0.826 & 0.588 & 0.489 & 0.382 & 0.280 & 0.193 & 0.108 & 0.066 \\
\hline & 100 & 0.840 & 0.589 & 0.490 & 0.383 & 0.286 & 0.193 & 0.108 & 0.066 \\
\hline & $\infty$ & 0.856 & & & & & & & \\
\hline & 10 & 0.753 & $0 . \overline{576}$ & 0.485 & 0.382 & 0.280 & 0.193 & 0.108 & 0.066 \\
\hline & 20 & 0.844 & 0.610 & 0.506 & 0.393 & 0.287 & 0.197 & 0.110 & 0.067 \\
\hline \multirow{5}{*}{$L_{/ B}=4$} & 50 & 0.903 & 0.623 & 0.513 & 0.397 & 0.289 & 0.198 & 0.110 & 0.067 \\
\hline & 100 & 0.923 & 0.625 & 0.514 & 0.398 & 0.289 & 0.198 & 0.110 & 0.067 \\
\hline & $\infty$ & 0.943 & & & & & & & \\
\hline & 10 & 0.778 & 0.591 & 0.495 & 0.388 & 0.284 & 0.195 & 0.109 & 0.067 \\
\hline & 20 & 0.888 & 0.631 & 0.520 & 0.402 & 0.292 & 0.199 & 0.111 & 0.067 \\
\hline \multirow{4}{*}{$L_{/ B}=5$} & 50 & 0.961 & 0.647 & 0.529 & 0.407 & 0.294 & 0.200 & 0.111 & 0.068 \\
\hline & $\begin{array}{l}100 \\
\infty\end{array}$ & $\begin{array}{l}0.985 \\
1.010\end{array}$ & 0.650 & 0.530 & 0.530 & 0.294 & 0.200 & 0.111 & 0.068 \\
\hline & 10 & 0.818 & 0.611 & 0.509 & 0.396 & 0.289 & 0.197 & 0.110 & 0.067 \\
\hline & 20 & 0.989 & 0.674 & 0.547 & 0.418 & 0.300 & 0.204 & 0.113 & 0.068 \\
\hline \multirow[t]{5}{*}{$L / B=10$} & 50 & 1.123 & 0.703 & 0.563 & 0.427 & 0.305 & 0.206 & 0.113 & 0.069 \\
\hline & 100 & 1.171 & 0.708 & 0.566 & 0.428 & 0.305 & 0.206 & 0.114 & 0.069 \\
\hline & $\infty$ & 1.221 & & & & & & & \\
\hline & 10 & 0.822 & 0.613 & 0.510 & 0.397 & 0.289 & 0.198 & 0.110 & 0.067 \\
\hline & 20 & 1.029 & 0.688 & 0.556 & 0.423 & 0.303 & 0.205 & 0.113 & 0.069 \\
\hline \multirow[t]{3}{*}{$L_{/ B}=20$} & 50 & 1.242 & 0.733 & 0.581 & 0.436 & 0.310 & 0.208 & 0.114 & 0.069 \\
\hline & 100 & 1.335 & 0.743 & 0.586 & 0.439 & 0.311 & 0.209 & 0.115 & 0.069 \\
\hline & $\infty$ & 1.433 & & & & & & & \\
\hline
\end{tabular}

(h)

Fig. 5 (contd). Displacement influence factors for non-homogeneous layer 


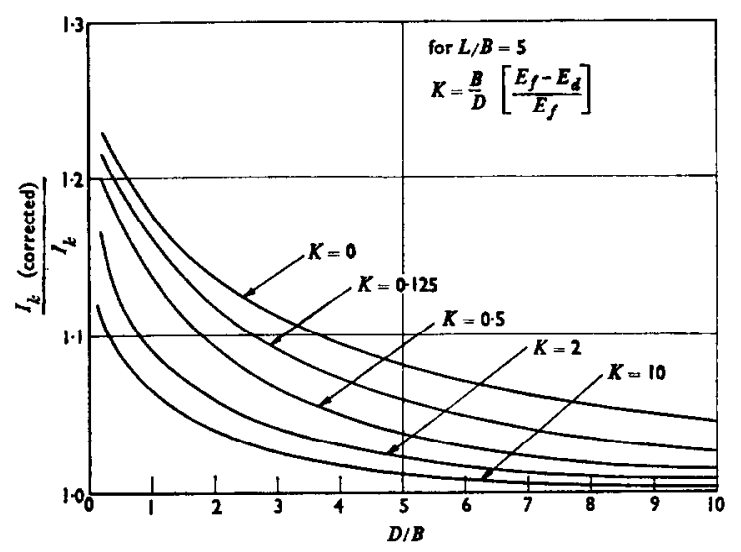

Fig. 6. Effect of Ueshita and Meyerhof Correction on influence factor, $I_{k}$

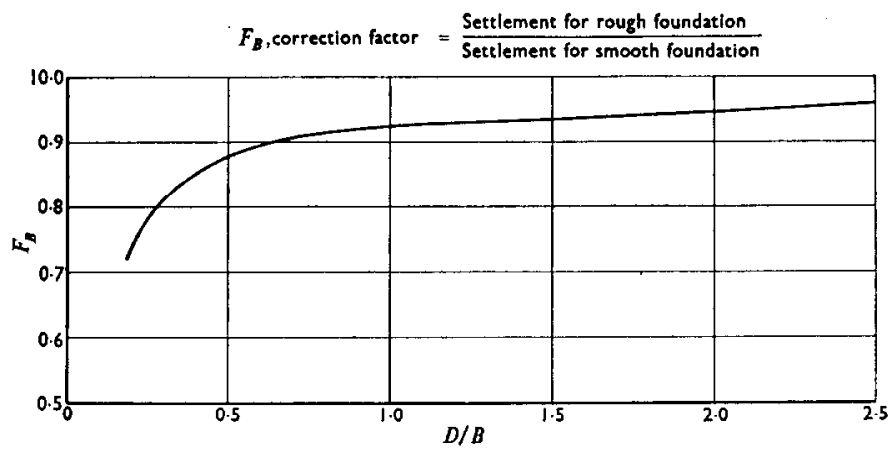

Fig. 7. Correction for adhesion of foundation to ground

analysis has incorporated this suggested procedure of Ueshita and Meyerhof. Thus the curves and table presented in Fig. 5 should be entered at a modified depth ratio of $1.2 D / B$ instead of $D / B$ in order to take due account of adhesion on the base of the layer. The assumption has been made that the Ueshita and Meyerhof procedure for $K=0$ is appropriate for $K>0$, although this has not been verified. The extent of the correction (for $L / B=5$ ) can be seen in Fig. 6. The correction is significant for low values of $D / B$ (i.e. for a relatively thin compressible layer) particularly for low values of $K$ (i.e. a small rate of increase of modulus with depth). The correction is slightly lower than that shown in Fig. 6 for values of $L / B$ less than five, and slightly higher for values of $L / B$ greater than five.

In order to compare observed and calculated settlements more realistically it has been considered appropriate to apply two further corrections to the computed values derived from Fig. 5 . The first of these is to take account of the friction at the contact between the underside of the foundation and the ground. In the preceding analysis it has been assumed that no friction develops at the foundation-ground interface, and no rigorous solution is yet available taking this into account for a rectangular area. It would, however, seem reasonable to proceed on the basis of the published results of some work on the axisymmetric case of a circular area on a semi-infinite elastic layer presented by Popova (1972). Where adhesion develops at the 
foundation-ground interface Popova showed that there is no influence for $\nu=0.5$ but that for $\nu=0.2$ the settlement may be over-estimated by between about $30 \%$ for a very thin layer, $D / B=0.25$, decreasing exponentially to about $8 \%$ for a thickness ratio $D / B$ of 1.0 or so. The variation of $F_{B}$ with $D / B$ is shown in Fig. 7. The second reduction factor $F_{H}$ takes account of the modified stress distribution for a foundation embedded depth $H$ below the rock surface. The amount of this reduction will depend on the geometry of the problem, i.e. $H / B$ and $L / B$ and also on the value of Poisson's ratio $\nu$. This problem was first studied by Fox (1948) for the case of $\nu=0.5$ only. More recently, Burland (1970) has examined, using a finite element analysis, the case of a load applied at the base of an unlined shaft for $\nu=0,0.25$ and 0.49 . It would seem reasonable to use this analysis in assessing the reduction factor, $F_{H}$ for the depth of embedment. The variation of $F_{H}$ with $H / B$, for the case $\nu=0.2$ is given in Fig. 8. It will seem that $F_{H}$ varies between unity for a foundation at the surface $(H / B=0)$ to a constant value of 0.80 when $H / B$ exceeds about 10 . These values are probably more realistic than those of Fox.

To summarize, the corrected calculated settlement, $s$, of the corner of a rectangular foundation of breadth $B$, resting on a non-homogeneous, elastic layer of thickness $Z$, may therefore be generally expressed as

$$
s=q \frac{B}{E_{\mathrm{f}}} I_{\mathrm{k}} F_{B} F_{H}
$$

where $q$ is the applied pressure ${ }^{3} ; E_{\mathrm{f}}$ is the drained elastic modulus at foundation level, increasing linearly at a rate defined by $E_{z}=E_{\mathrm{f}}+K_{z} Z, I_{\mathrm{k}}$ is the displacement influence factor dependent on the geometry, $D / B$ and $L / B$, and on the degree of non-homogeneity; $I_{\mathrm{k}}$ is obtained from Fig. 5(a)-(g) for values of $D / B \leqslant 10$ or from Fig. 5(h) for values of $D / B>10$, for a Poisson's ratio $\nu=0 \cdot 2$, by entering at a modified depth ratio of $1 \cdot 2 D / B$ to take due account of the Ueshita and Meyerhof analysis. The $K$ value is obtained from eqn (5); $F_{B}$ is the correction factor to take account of the adhesion between the base of the foundation and the ground (Fig. 7); $F_{H}$ is the correction factor for the depth of embedment, $H$, of the foundation below the rock surface (Fig. 8).

For many practical cases the foundation is relatively rigid, and it is necessary to compare the observed settlement with a calculated average settlement. The settlement of a flexible rectangular foundation is then calculated at its centre $S_{0}$, at a corner $S_{\mathrm{c}}$, and at the mid-point on the longer edge $S_{\mathrm{e}}$, and the equivalent 'rigid' settlement is approximately given by

$$
S=\frac{1}{3}\left(S_{\mathrm{o}}+S_{\mathrm{c}}+S_{\mathrm{e}}\right)
$$

Having said all this, it must be pointed out that there are in practice many cases when even an approximate linear non-homogeneous modulus profile cannot be established. In such cases it is necessary to resort to a simple 'spread-of-load' calculation in which the average stress at a given level is calculated from the average stress at foundation level reduced in proportion to the ratio of surface area at the given level to surface area at foundation level, the surface areas being defined by boundaries extending downwards from the foundation area and inclined outwards at a selected slope, often taken as one horizontal in two vertical. The modulus of compressibility is taken from elastic theory as

$$
m_{\mathrm{v}}=\left(\frac{1}{E}\right) \frac{\left(1-2 \nu^{\prime}\right)\left(1+\nu^{\prime}\right)}{\left(1-\nu^{\prime}\right)}
$$

\footnotetext{
${ }^{3}$ Net applied pressure, if recovery of heave is assessed separately; otherwise gross applied pressure in order to make an approximate allowance for recovery of heave.
} 


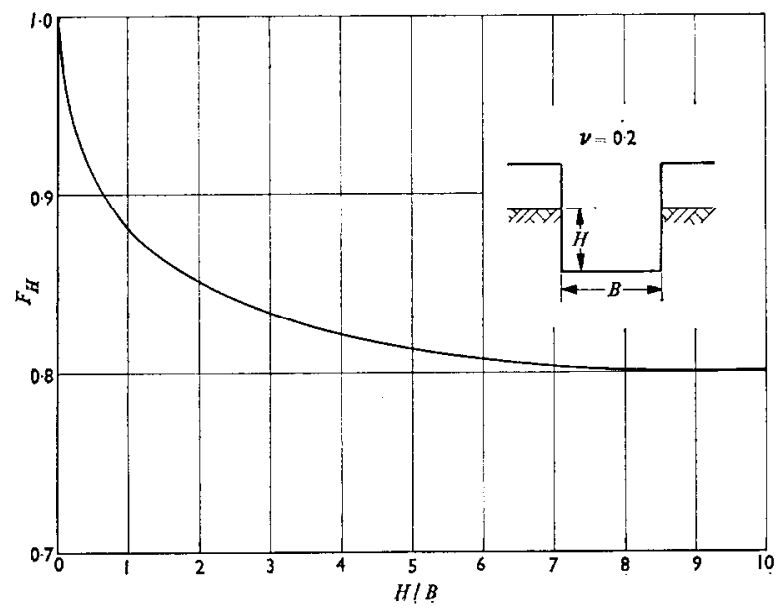

Fig. 8. Correction for embedment

or

$$
m_{\mathrm{v}}=\frac{0.9}{E}, \quad \text { for } \quad \nu^{\prime}=0.2
$$

In this and the preceding analysis the assumption is made that the distribution of stress beneath the loaded area is unchanged by non-homogeneity and anisotropy. It is recognized that this cannot be true, but in the absence of any general solution for these cases the stress distributions for the homogeneous, isotropic, elastic medium have been adopted.

\section{DETERMINATION OF MODULUS VALUES}

In the discussion and comparison of modulus values and modulus profiles which follow, values of the drained modulus of elasticity, $E$, have been obtained from back-analysis of observed settlements, from plate loading tests and pressuremeter tests in the field and from laboratory tests on rock cores and block samples. Attempts have also been made to evaluate $E$ from pile loading tests.

The basis for back-analysis of observed settlement has been given in the preceding section. Plate loading test procedures are generally straightforward, although care is needed to avoid disturbance of the ground below plate level. Control of groundwater is of paramount importance; uplift and seepage can easily invalidate the test results.

\section{Pressuremeter}

The pressuremeter is an in situ testing device consisting of a cylindrical probe which is placed, as a tight fit, in a drill-hole and expanded laterally in stages at a controlled rate against the resistance of the ground. Pressure and corresponding volume change of the ground are measured for each load increment and a modulus, $E_{\mathrm{p}}$, is derived from the pressure-volume change plot. A further modulus, $E_{+}$, is derived from a reloading cycle. For a more detailed description see Ménard $(1957,1965)$. In this lecture, the pressuremeter modulus $\left(E_{\mathrm{p}}\right.$ or $\left.E_{+}\right)$ has been regarded as a drained modulus, although there may be cases where drainage is not complete. The interpretation of pressuremeter values and their relationship to modulus 
values otherwise determined is a complex matter, much affected by the pattern and nature of jointing in the rock. In general, experience has shown that in stronger rocks the reloading modulus, $E_{+}$, is a better representation of the overall rock modulus or 'field' modulus, whereas in the weak rocks, with tight joints, the field modulus is more appropriately represented by the value of the first loading modulus $E_{\mathrm{p}}$, or some value intermediate between $E_{\mathrm{p}}$ and $E_{+}$. These factors have been borne in mind when drawing lines through pressuremeter test values to represent modulus profiles, but it is not intended that such lines are necessarily 'design values'. Rather, they are intended to make possible comparison between one site and another.

As first introduced into the UK, the pressuremeter was BX size (57 mm diameter). It was designed for use in soils, and it suffered the disadvantage when used in weak rocks that large corrections to the volume change readings were necessary in respect of the expansion under pressure of the tubes connecting the pressure vessel at the surface and the probe. The tests at Cottam were done with such a device. It was also used at Daresbury where trials were made to select a drilling method giving minimum disturbance for pressuremeter testing (Meigh and Greenland, 1965). Later, Model $G$ was introduced in which the tubes connecting the probe to the pressure vessel are surrounded by tubes under the same pressure, thus avoiding the high pressure corrections. Model G, in BX size, was used at the Lichfield sites, and at Hams Hall, High Marnham, West Burton, Portskewett, Runcorn, Heysham and Cardiff. The most recent model, G(NX), has an outside diameter of about $73 \mathrm{~mm}$. It also has the advantage of a sophisticated, laminated metal outer sheath, which minimizes bursting of the probe in thinly interbedded rocks with large differences in modulus. It was used at the Ml bridge site, near Loughborough, and at Redcar.

\section{Laboratory tests}

Laboratory tests for modulus include uniaxial and triaxial compression tests in which axial compression of the specimen is measured by dial gauges between end platens or by electrical resistance strain gauges cemented to the specimen. The dial gauge method is satisfactory only for very weak rocks, where adhesion of strain gauges is not practicable.

Oedometer tests have also been used on the weaker rocks, the drained modulus being derived from the modulus of compressibility, $m_{\mathrm{v}}$, by the relationship given in eqn (9). However, experience has shown that oedometer tests are not satisfactory in unweathered Keuper, but are of some use in the more highly weathered Keuper Marl, the accuracy of the results increasing with the degree of weathering (Hobbs, 1975).

\section{Pile loading tests}

Pile loading tests are difficult to interpret in terms of modulus because of uncertainty about the amount of load carried in skin friction, both in overburden and in the 'rock socket', and uncertainty about the amount of deformation of the pile shaft under load. There is also the problem of movement arising from disturbance during pile construction of the material immediately below the pile toe, which is a function of the method of constructing the pile.

\section{KEUPER-MIDLANDS AREA AND LINCOLNSHIRE}

\section{The Birmingham Basin}

The published work on the Keuper has mainly come from Birmingham University, and it has concerned part of the Midlands area. Much of the research was funded by The Construction Industry Research and Information Association (CIRIA), and the results have been presented in a series of reports to that organization. Of particular note is a scheme of weathering of the Keuper Marl developed by Skempton and Davis in 1966, and published by Chandler 
(1969). A condensed version is given in Table 3. This scheme has been sometimes misused through no fault of its originators. In CIRIA Report 47, by Davis and Chandler (1973), it was made clear that the authors were limiting their considerations to the red-brown mudstones and their weathering products, which they referred to as the Keuper marl (small $\mathrm{m}$ ). I find this nomenclature inconvenient, and prefer to call this material Birmingham mudstone, partly because of where it is found and partly in recognition of the Birmingham University research work.

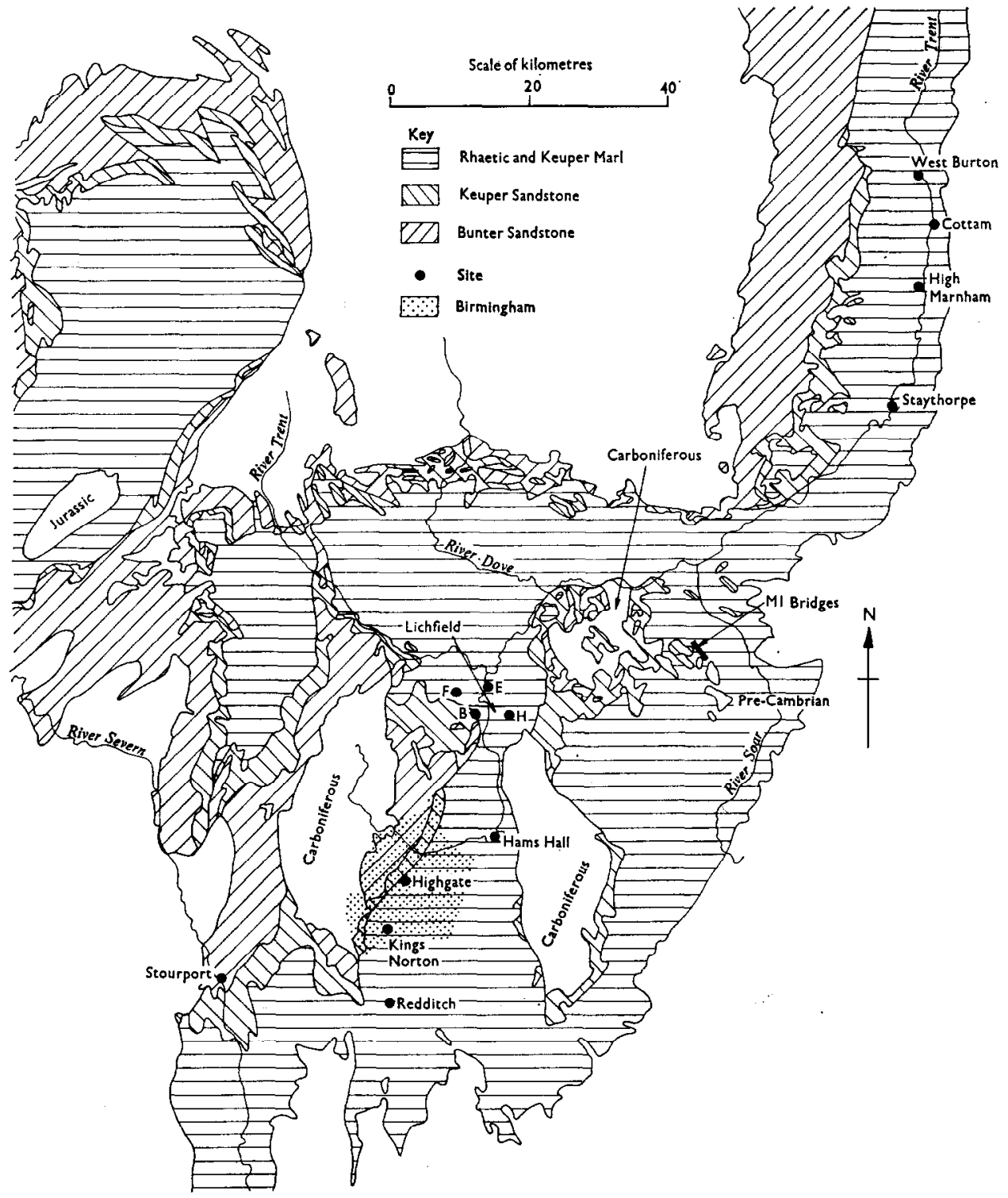

Fig. 9. Triassic geology of the Midlands. Based on IGS 10 miles to one inch sheet 


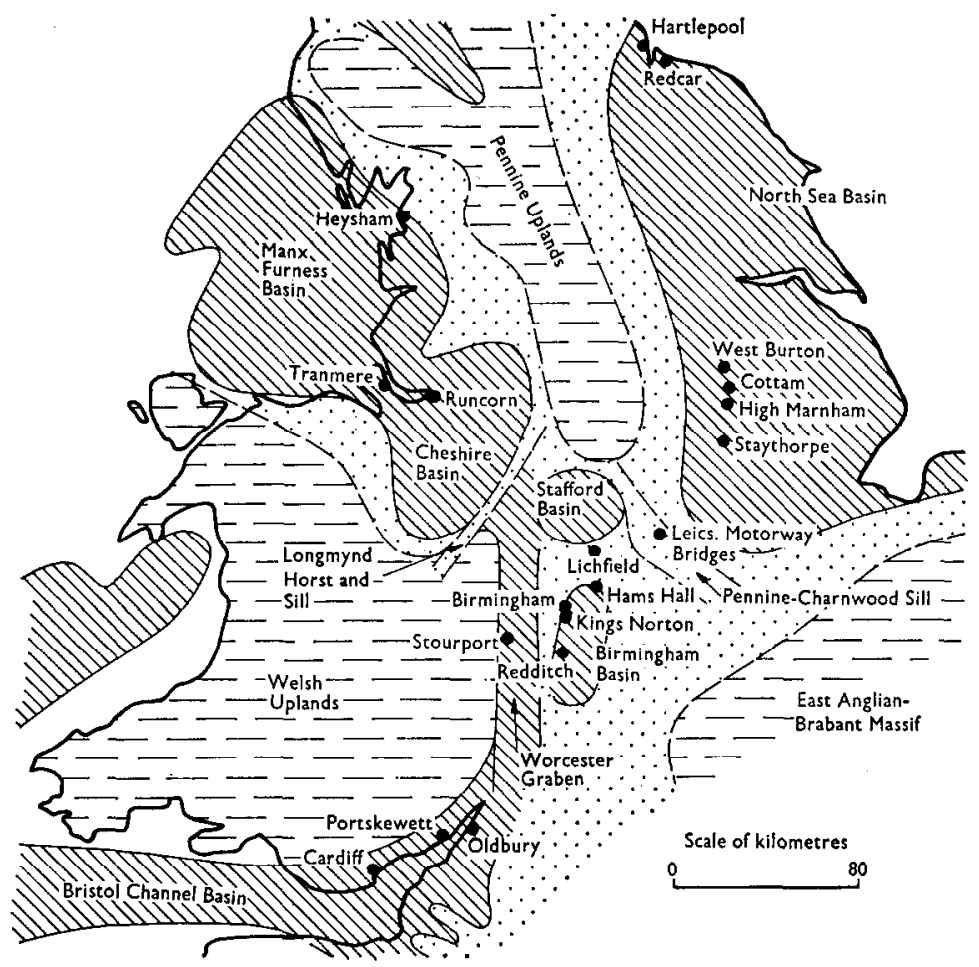

Fig. 10. Site locations superimposed on part of main basins map

Chandler and Davis also pointed out that 'a more comprehensive classification scheme would recognise the different strata within both the weathered and unweathered zones'. This is a most important limitation.

The sites studied by Chandler in connexion with the weathering scheme included Kings Norton, on the southern edge of Birmingham, and the nearby Bells Lane. Davis studied a site at Highgate near the centre of Birmingham. These are shown against the Triassic geology of the Midlands in Fig. 9 and Fig. 10 shows their position in relation to the uplands and basins

Table 3. Weathering scheme for Keuper Marl (after Skempton and Davis, 1966, and Chandler, 1969) (abbreviated)

\begin{tabular}{|c|c|c|c|}
\hline & Zone & Description & $\begin{array}{l}w \\
\%\end{array}$ \\
\hline Fully weathered & $\mathrm{IVb}$ & Matrix only & \multirow{2}{*}{$18-15$} \\
\hline \multirow[t]{3}{*}{ Partially weathered } & IVa & Matrix, with occasional pellets $<\frac{1}{8}$ in. dia. & \\
\hline & III & Matrix, with frequent lithorelicts up to $1 \mathrm{in}$. & $12-20$ \\
\hline & II & Angluar blocks of unweathered marl with virtually no matrix & \multirow{2}{*}{$5-15$} \\
\hline Unweathered & I & Mudstone (often fissured) & \\
\hline
\end{tabular}



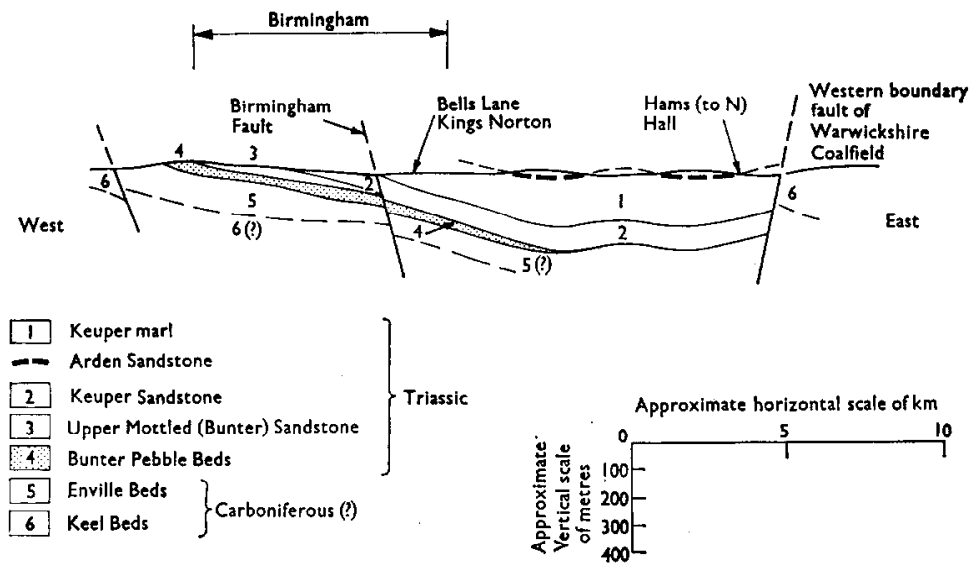

Fig. 11. Section through Birmingham Basin

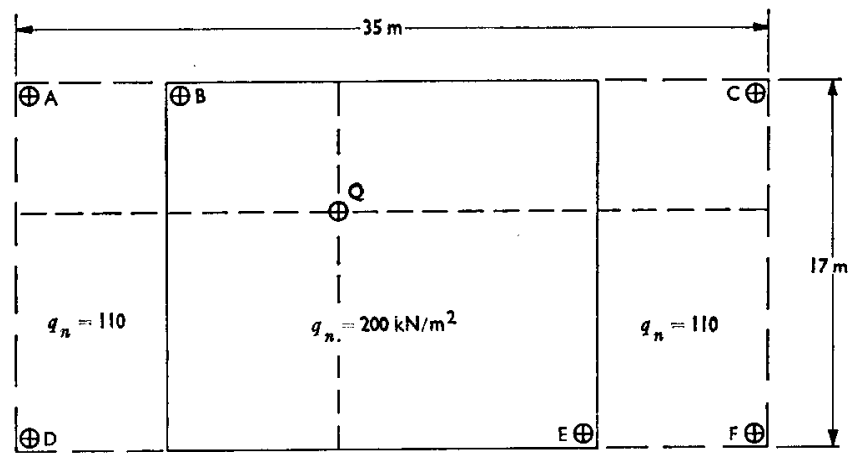

Fig. 12. Highgate, Birmingham: equivalent loading diagram. Gross load $=140 \mathrm{MN}$

described earlier (Fig. 2). They are on the western edge of the Birmingham Basin ${ }^{4}$ and in the lower part of the Keuper Marl, as shown in Fig. 11.

At Redditch, a few kilometres to the south, the materials identified in deep trial pits conformed to the weathering pattern described by Chandler and Davis, as did the average moisture contents which were: Zone IV, $26 \%$; Zone III, $22 \%$; Zone II, $15 \%$.

\section{Highgate, Birmingham}

At this site a 20 -storey block of flats with a plan area $35 \mathrm{~m}$ by $17 \mathrm{~m}$ was founded below a single-storey basement on pad and strip footings, $3.7 \mathrm{~m}$ below ground level, covering most of the area (Davis, 1970). The groundwater level was some $14 \mathrm{~m}$ below ground level. A simplified equivalent loading diagram is shown in Fig. 12. Settlements were observed at the lettered points, that at $Q$ reaching approximately $55 \mathrm{~mm}$.

If the settlement is back-analysed in terms of a constant drained modulus of elasticity $\left(K_{z}=0\right)$, then the required value is $E=83 \mathrm{MN} / \mathrm{m}^{2}$. The site investigation, using cable-

\footnotetext{
4 The name Birmingham Basin does not appear to have been used previously, although its presence has been indicated.
} 


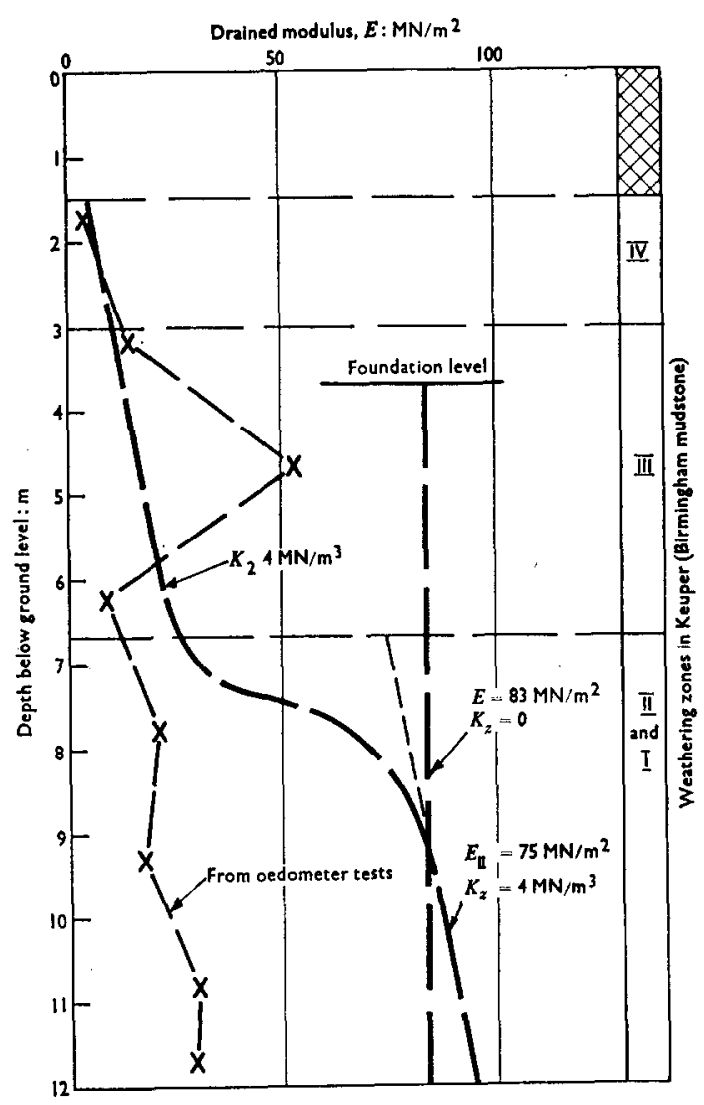

Fig. 13. Highgate, Birmingham
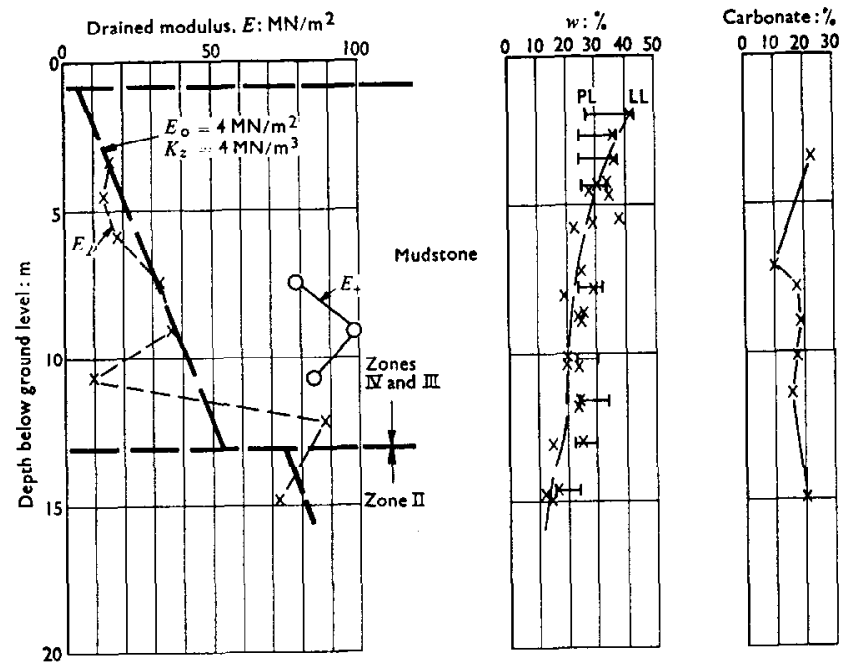

Fig. 14. H22: Harlaston near Lichfield 


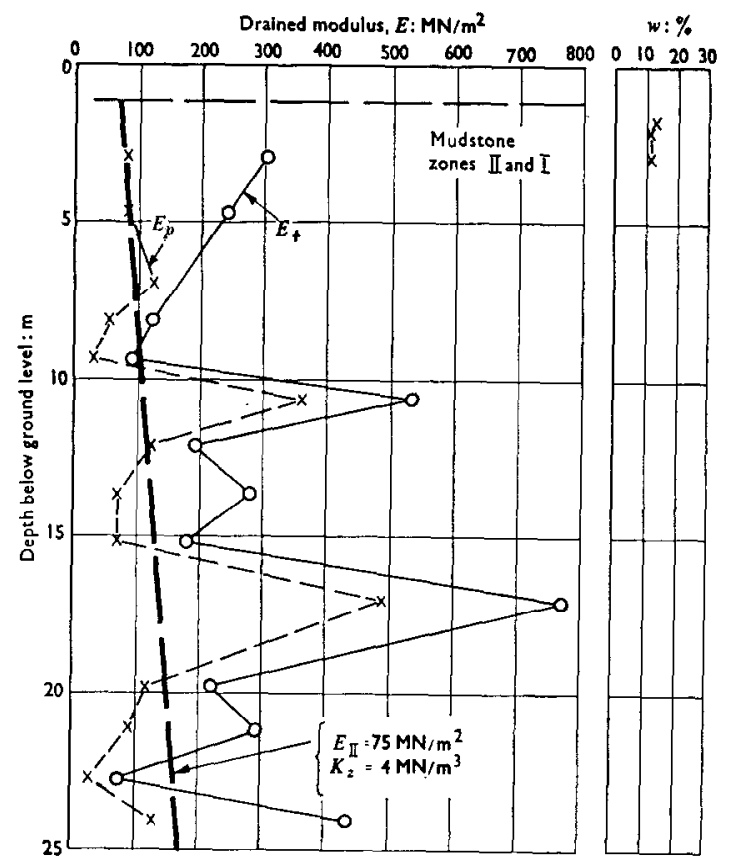

Fig. 15. FA 29: Fradley Airfield near Lichfield

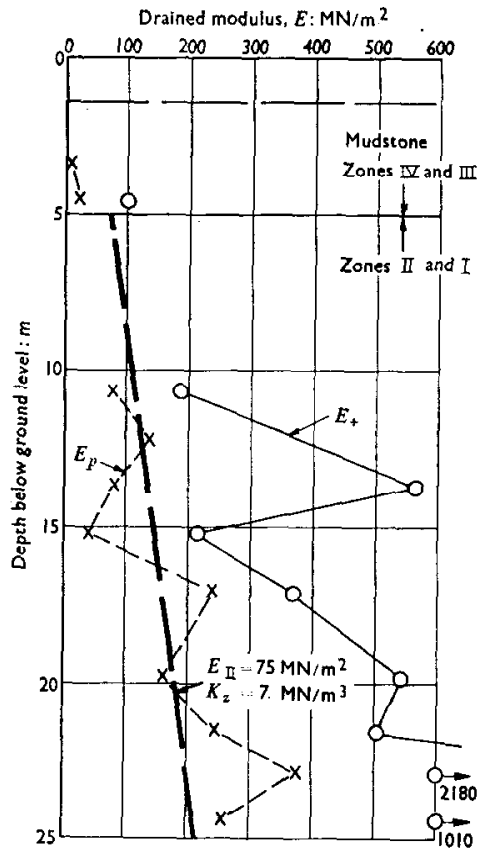

$w: \%$

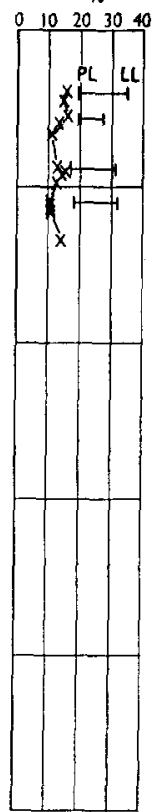

Fig. 16. EP 23: Elford Park near Lichfield 


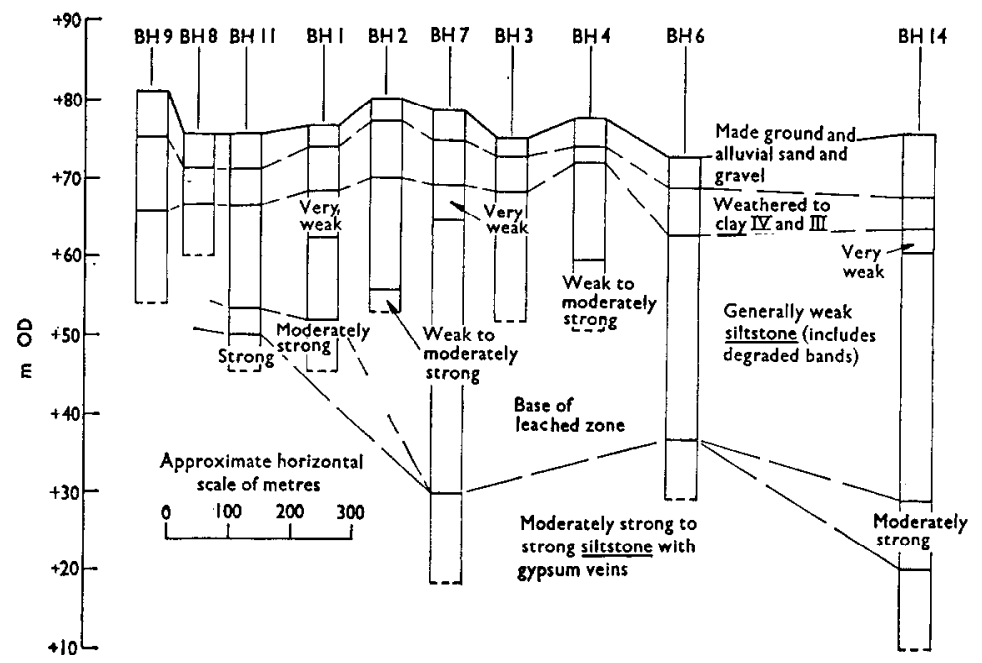

Fig. 17. Hams Hall: Section through boreholes

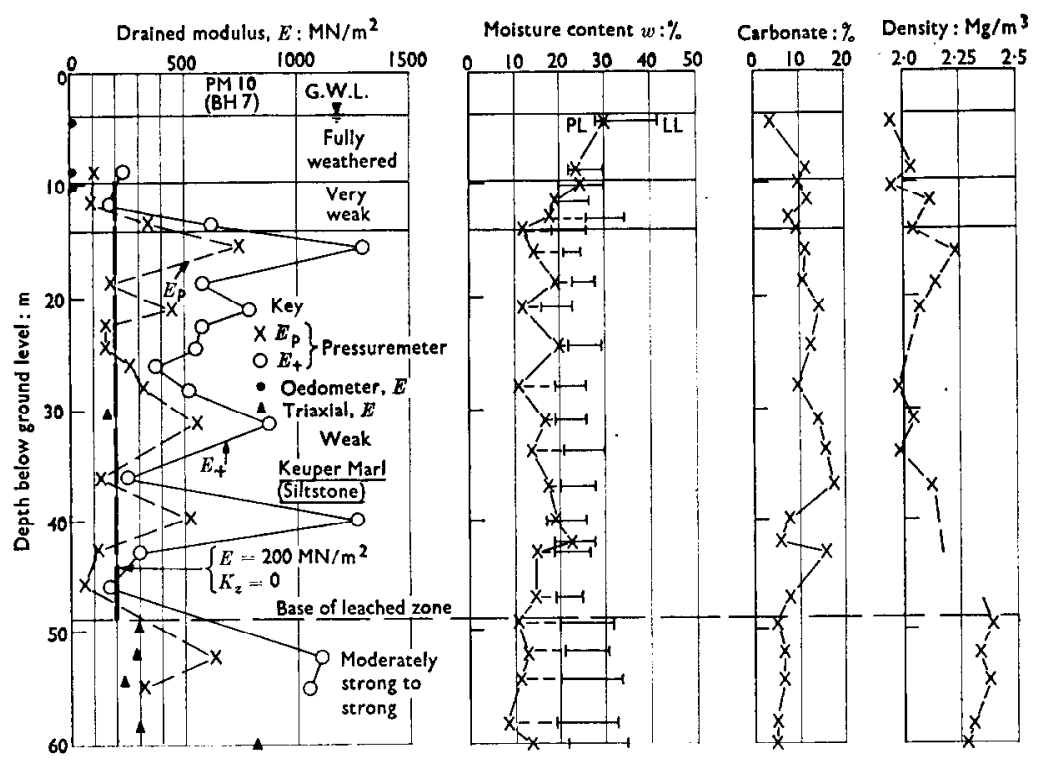

Fig. 18. BH7: Hams Hall

percussion boring and open-drive sampling with $100 \mathrm{~mm}$ diameter samplers, revealed mudstones, weathered to Zone IV at the surface (Table 3), grading to Zones III, II and I (Fig. 13). Oedometer test results expressed as $E=0.9 / m_{\mathrm{v}}$ gave the values shown in Fig. 13, falling well short of $E=83 \mathrm{MN} / \mathrm{m}^{2}$. If, however, a composite modulus profile is 'borrowed' from the Lichfield site described in the next section, as marked in Fig. 13, then the corresponding calculated settlement is very close to the observed $55 \mathrm{~mm}$. The Lichfield sites (Harlaston and Fradley Airfield) are in the shelf area between the Birmingham and Stafford Basins (Fig. 10), 

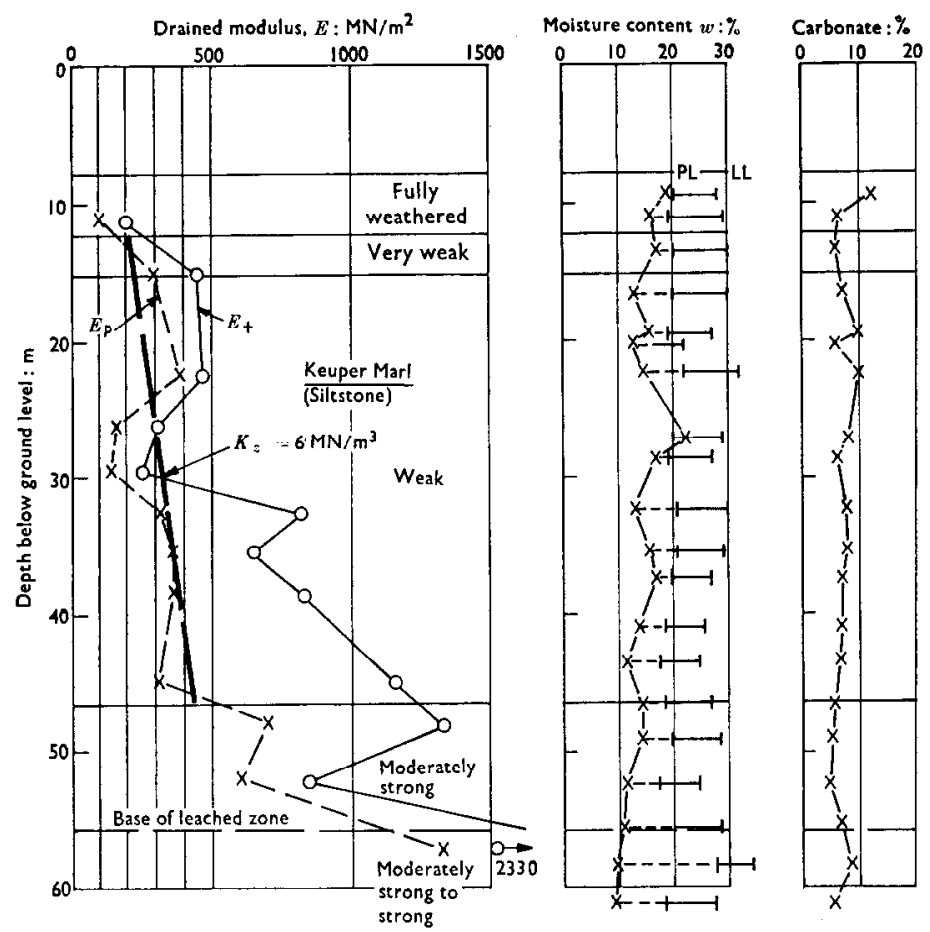

Fig. 19. BH14: Hams Hall

in the lower part of the Keuper Marl, and it is reasonable to suppose that the rock at those sites would be similar in lithology to that at the Highgate site. It is realized that alternative modulus profiles would also 'fit' the observed settlement, but in the absence of other data this profile is preferred.

\section{Lichfield sites (shelf area)}

In the Lichfield area, a preliminary investigation was made at a number of sites, as shown in Figs 9 and 10. As alrcady mentioned, these sites are in the lower part of the Keuper Marl, in the shelf area between the Birmingham and Stafford Basins. At Harlaston (Fig. 14), pressuremeter tests in the weathered mudstone (Zones IV and III) showed a modulus profile defined by $E_{0}=4 \mathrm{MN} / \mathrm{m}^{2}, K_{z}=4 \mathrm{MN} / \mathrm{m}^{3}$. The step in the modulus profile at the junction of Zones III and $\mathrm{II}$ is reflected in the moisture content profile. Carbonate content is fairly constant at about 17\%. At Fradley Airfield (Fig. 15) relatively unweathered mudstone (Zones II and I) is found near the surface and the modulus profile is given approximately by $E_{\mathrm{II}}=75 \mathrm{MN} / \mathrm{m}^{2}$; $K_{z}=4 \mathrm{MN} / \mathrm{m}^{3}$, where $E_{\mathrm{II}}$ is the modulus at the top of the relatively unweathered mudstone. At Elford Park (Fig. 16) Zoncs IV and III mudstone is followed by Zones II and I mudstone at $5 \mathrm{~m}$ below ground level, where $K_{z}$ is somewhat higher at $7 \mathrm{MN} / \mathrm{m}^{3}$, but this may indicate a slight change in lithology with depth. The fourth site, Brookhay, (B on Fig. 9), is at the Keuper Marl-Keuper Sandstone boundary. Keuper Waterstones were encountered, described as brownish micaceous sandstones alternating with red silty marls and shales. In the sandstones $E_{\mathrm{p}}$ values were $500 \mathrm{MN} / \mathrm{m}^{2}$ or more, and $E_{+}$values were $1500 \mathrm{MN} / \mathrm{m}^{2}$ or more. 
Hams Hall (Birmingham Basin)

The Hams Hall site is in the Birmingham Basin, on its north-eastern edge, but as shown in Fig. 11 it is in the upper part of the Keuper Marl, just below the Arden Sandstone. It differs from the sites in the lower part of the Keuper Marl, in the western part of the Birmingham Basin and in the shelf area between the Birmingham and Stafford Basins, in two respects. Firstly, the rock is predominantly siltstone, thin-bedded, with gypsum bands up to $40 \mathrm{~mm}$ in thickness. Secondly, it is leached in its upper part (Fig. 17); gypsum has been removed, and there are degraded bands associated with grey-green siltstone horizons.

Triaxial tests to measure the drained modulus, $E$, were done in the laboratory, in this case using dial gauges between end platens for deformation measurement. Oedometer tests were also carried out. Pressuremeter tests were done in drill-holes. The results of some of these are shown in Figs 18 and 19. It is to be noted that below the leached zone, high modulus values were recorded, density was relatively high and carbonate content relatively low. Triaxial modulus values were low, because of the method of testing. Oedometer test results, as often, were unrealistically low. Borehole 14 (Fig. 19) showed an increase of modulus with depth, whereas Borehole 7 (Fig. 18) did not, indicating less severe leaching in Borehole 14. It may be noted that carbonate contents above the leached zone were lower in Borehole 14 than in Borehole 7, closer in fact to the carbonate contents in the unleached zone. Carbonates may be an important indicator; it is now our practice wherever possible to measure carbonate content when investigating the Keuper.

\section{MI bridges, near Loughborough (Pennine-Charnwood Sill)}

We move from the Birmingham Basin north-eastwards across the Pre-Cambrian PennineCharnwood Sill (Fig. 10), into marginal facies of the Keuper Marl. Davis (1967) reported settlements of three bridges, Nos 201 and 202 carrying the interchange with the Ashby-de-laZouche road over the Ml, and No. 199 some $1 \frac{1}{2} \mathrm{~km}$ to the south, carrying the Ml over a minor road. Dimensions and loadings of the foundations are given in Table 4, from which it can be seen that the foundation of bridge 199 is long, narrow, and lightly loaded. The

Table 4. Leicestershire motorway bridges

\begin{tabular}{|c|c|c|c|c|c|c|}
\hline \multirow[t]{2}{*}{ Bridge No. } & \multicolumn{3}{|c|}{ Foundation dimensions } & \multicolumn{2}{|c|}{ Bearing pressure, $\mathrm{kN} / \mathrm{m}^{2}$} & \multirow{2}{*}{$\begin{array}{c}\text { Observed } \\
\text { settlement, } \\
\text { mm }\end{array}$} \\
\hline & $\begin{array}{l}L \\
\mathbf{m}\end{array}$ & $\begin{array}{l}B, \\
\mathrm{~m}\end{array}$ & $\begin{array}{c}\text { Depth below } \\
\text { finished GL, } \\
\text { m }\end{array}$ & Gross & Net & \\
\hline 199 & 41 & $2 \cdot 75$ & $1 \cdot 5$ & 190 & 160 & $10 \cdot 2$ \\
\hline $\begin{array}{l}201 \\
202\end{array}$ & $11 \cdot 6$ & $6 \cdot 1$ & $2 \cdot 45$ & 280 & 240 & $\begin{array}{l}13 \cdot 7 \\
15 \cdot 2\end{array}$ \\
\hline
\end{tabular}

Table 5. Leicestershire motorway bridges: modulus values for $K_{z}=0$

\begin{tabular}{c|c}
\hline Source of modulus value & $E, \mathrm{MN} / \mathrm{m}^{2}$ \\
\hline PLT 2 & 32 \\
PLT 3 & 45 \\
Bridge 199 & 75 \\
Bridges 201 and 202 & 95 \\
\hline
\end{tabular}



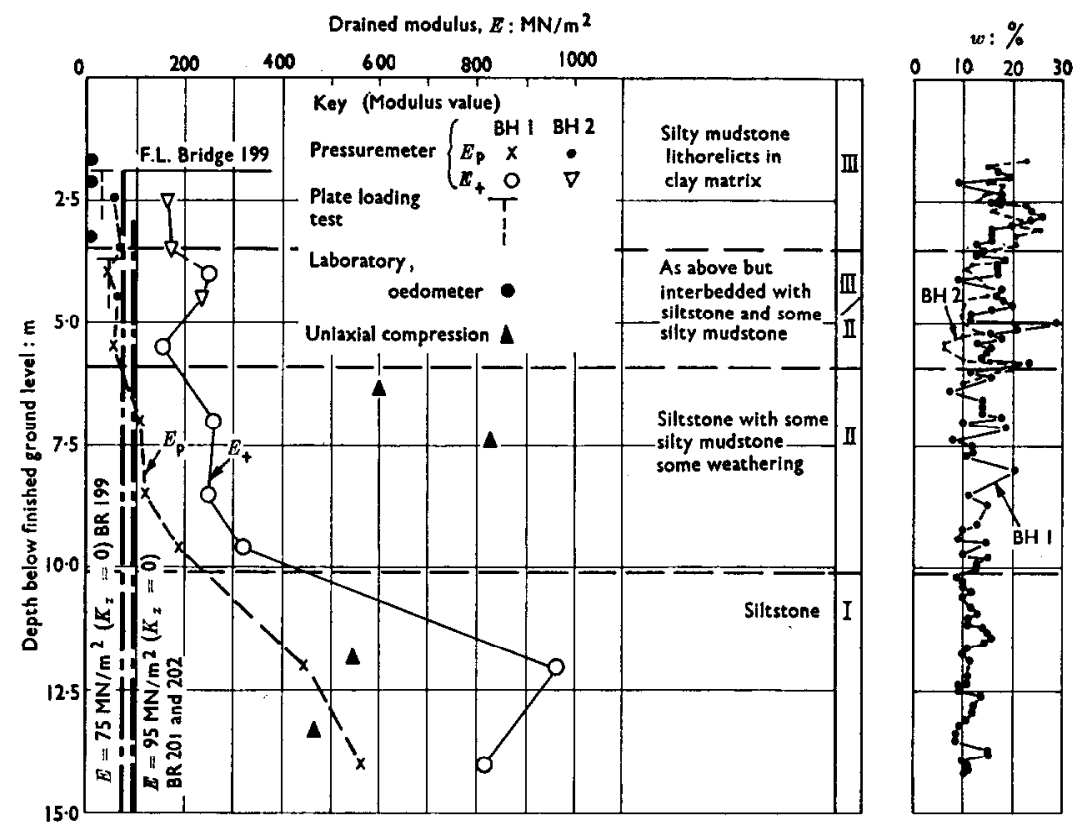

Fig. 20. Leicestershire M1 bridges

other two have main foundation footings with $L / B=2$, and somewhat heavier loading. The observed settlements were small, $10 \mathrm{~mm}$ for bridge 199 and averaging $14.5 \mathrm{~mm}$ for bridges 201 and 202.

From the results of cable-percussion borings the rock was zoned. Bridge 199 was thought to be founded in Zone III marl, whereas bridges 201 and 202 appeared to be founded in Zone I marl, with possibly a thin layer of Zone II below foundation level. At a later date, additional borings were put down and plate loading tests were carried out in pits as part of the Birmingham University research programme. The plate loading test site was some $40 \mathrm{~m}$ from the foundation of bridge 199 on which settlements were measured. Oedometer tests and Rowe cell tests were done on specimens from open-drive samples and on blocks cut from the trial pits. All of these gave considerably lower modulus values than those obtained from the plate loading tests (Fig. 20).

Table 5 and Fig. 20 give values of drained modulus $E$, calculated from the plate loading tests and from the observed settlements in each case assuming a constant modulus with depth (i.e. $K_{z}=0$ ). As pointed out by Davis, the plate loading test results cannot on this basis be reconciled with the observed settlements. An attempt was made to fit the observed settlements to the Birmingham mudstone modulus profile $\left(K_{z}=4 \mathrm{MN} / \mathrm{m}^{3}\right)$ but this was unsuccessful. It was then realized that on the basis of the known geology the profile in this marginal area of the North Sea Basin would not in any case be expected to be similar to that in the Birmingham Basin, and a drill and pressuremeter were therefore sent to the site for further investigation. The results are shown in Fig. 20. The drilling revealed a complex profile of interbedded siltstones and silty mudstones, with a complex weathering profile (in effect a superposition of two weathering profiles, one in silty mudstone and the other in siltstone) which cannot be represented by the Chandler weathering scheme. ${ }^{5}$ The siltstone proportion increases with depth

5 Although the moisture content profile is somewhat similar (Fig. 20) some of the siltstones have markediy lower moisture contents. 

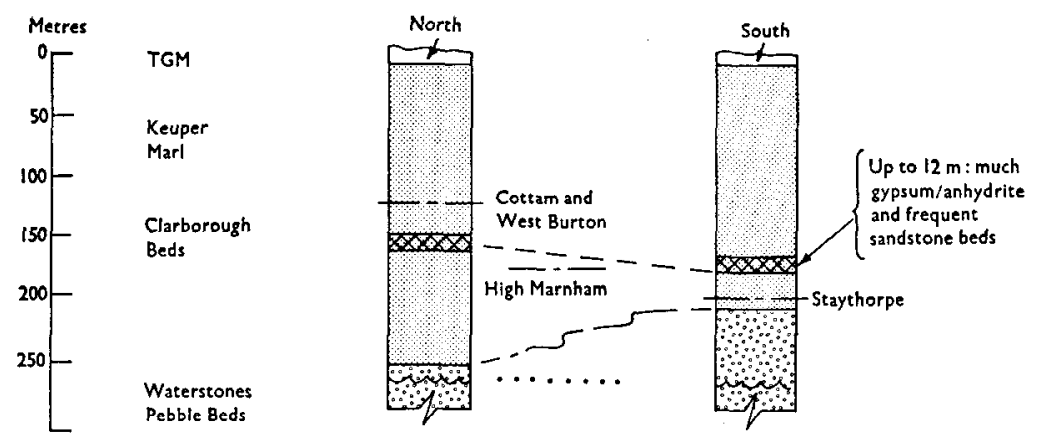

Fig. 21. Triassic succession in Lincolnshire appropriate to River Trent power stations

and in the unweathered rock, below $10 \mathrm{~m}$ below finished ground level, the rock is entirely siltstone. This is reflected in the pressuremeter modulus values. Uniaxial compression tests were done, to measure $E$, on siltstone core obtained from the pressuremeter drill-holes. The results are shown on Fig. 20; some very high values were obtained on specimens with relatively low water content. It is also to be noted that the $E_{\mathrm{p}}$ values in the weathered zone are in close agreement with the modulus values obtained from the plate loading tests.

A settlement calculation has been made using a profile of modulus passing through the two plate loading test values and following through the $E_{\mathrm{p}}$ values down to about $10 \mathrm{~m}$ below finished ground level. Below this level the modulus values are too high to affect the calculated settlement. The calculated settlement is in very close agreement with that observed for bridge 199 , whereas a calculation based on the Birmingham mudstone profile $\left(K_{z}=4 \mathrm{MN} / \mathrm{m}^{3}\right)$ is widely out. A similar calculation was done for bridges 201 and 202 . The result is sensitive to the assumption made about the foundation levels of these bridges relative to the modulus profile, but gives results of the right order.

\section{Lincolnshire (North Sea Basin)}

Investigations have been carried out at a number of power station sites in the Trent Valley (Fig. 9). These sites are within the western edge of the North Sea Basin. From south to north the sites move up the Keuper succession (Fig. 21), Staythorpe in the south being in the lower part of the Keuper Marl, just above the Waterstones. High Marnham is in the lower to middle part of the Keuper Marl, just below the Clarborough beds, which are highly gypsiferous. Cottam and West Burton are above the Clarborough beds, in the middle part of the Keuper Marl. Feed of material from the south would have been barred by the Charnwood Sill, at least during the early part of the Keuper, and it is probable that the materials have been derived from the Pennine Uplands and the East Anglian Massif.

Staythorpe. Here mudstones were encountered, with subordinate siltstones and sandstones, with regular flat dips to the east. Gypsum was present in bands up to $150 \mathrm{~mm}$ thick. There are no pressuremeter or plate loading test data on the rock at Staythorpe. Loading tests were carried out on bored piles ranging in diameter from $250 \mathrm{~mm}$ to $600 \mathrm{~mm}$. Pile loading tests are difficult to interpret, as noted above. However, these tests indicate a value of $E$ in the upper part of the relatively unweathered rock of about $60 \mathrm{MN} / \mathrm{m}^{2}$, similar to the value for Birmingham mudstone at this depth. 

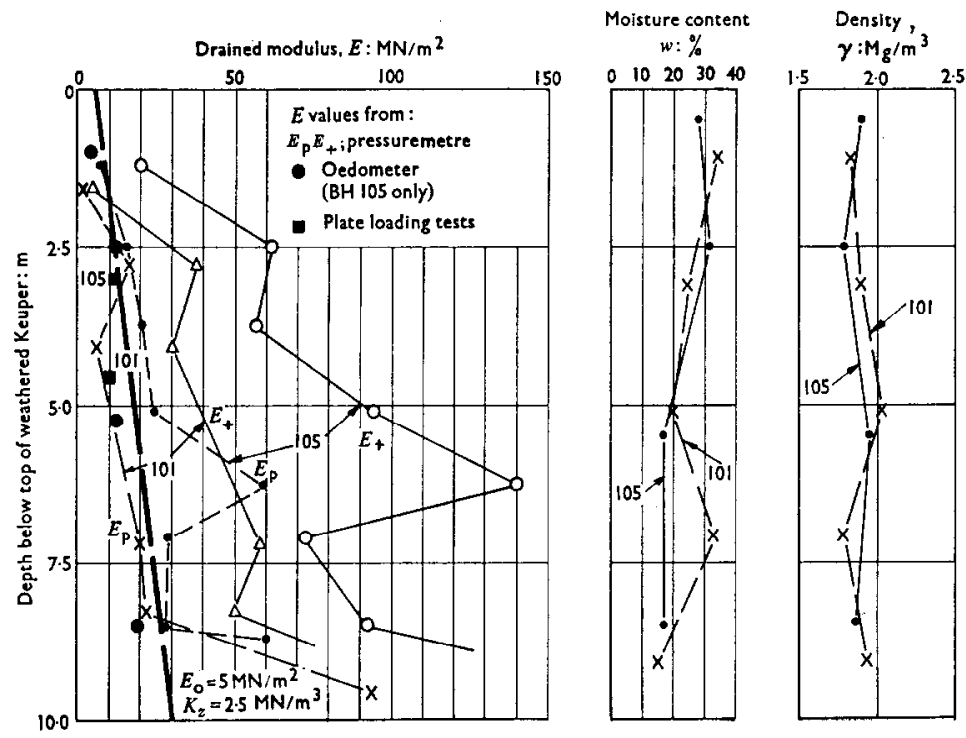

Fig. 22. High Marnham: weathered zone of Keuper

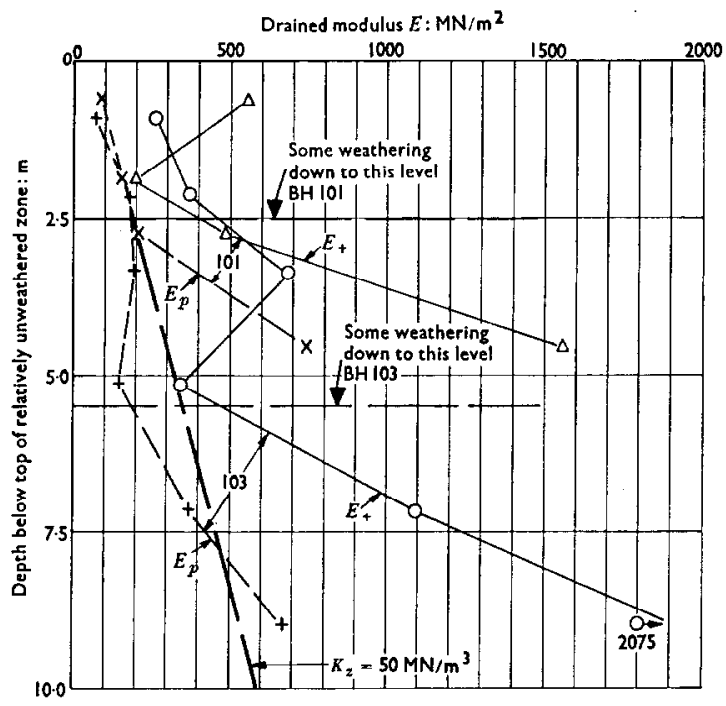

Fig. 23. High Marnham: relatively unweathered zone of Keuper (siltstone with gypsum bands)

High Marnham. Here there was a variable thickness of weathered Keuper overlying predominantly siltstones with gypsum bands $50 \mathrm{~mm}$ to $150 \mathrm{~mm}$ thick. Fig. 22 shows a profile through the weathered zone where it was thick with results of pressuremeter tests, oedometer tests and plate loading tests carried out in pits. A sketched profile through the pressuremeter $E_{\mathrm{p}}$ values gives $E_{0}=5 \mathrm{MN} / \mathrm{m}^{2}, K_{z}=2.5 \mathrm{MN} / \mathrm{m}^{3}$, not dissimilar to the weathered Birmingham mudstone. Platc loading tests in pits gave somewhat lower values of $E$ than the corresponding 


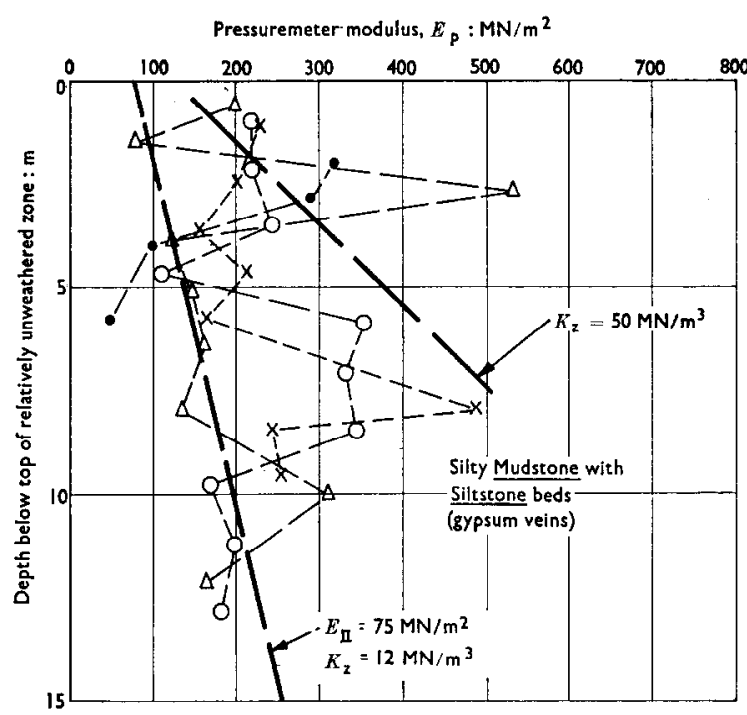

Fig. 24. Cottam

pressuremeter tests. This is not surprising as the report on the plate loading tests refers to heavy seepage and continuous pumping.

Figure 23 shows a profile at High Marnham at a point where the weathered zone was thinner. $E$ was between 150 and $200 \mathrm{MN} / \mathrm{m}^{2}$ at the upper surface of the relatively unweathered siltstone, increasing at about $50 \mathrm{MN} / \mathrm{m}^{2}$ per metre of depth, a very much higher rate than in the Birmingham mudstone.

Cottam. Here silty mudstone alternated with siltstone, extensively laminated throughout by fine gypsum veins which also occur as occasional bands up to $150 \mathrm{~mm}$ thick. Results of pressuremeter tests in relatively unweathered rock in one of the holes are given in Fig. 24. Two families of results can be discerned, although not clearly; one family, in siltstone, gives $K_{z}=50 \mathrm{MN} / \mathrm{m}^{3}$, as at High Marnham; the other, presumably in the silty mudstone, shows $K_{z}=12 \mathrm{MN} / \mathrm{m}^{3}$. The pressuremeter tests at this site were done in non-cored BX holes, put down with a wagon-drill, bclow the water table, and it is possible, that some softening may have occurred in the silty mudstone. Pile loading tests were done on piles founded in the stronger layers. These are difficult to interpret, for reasons already given, but it would appear that the modulus value of the materials below pile toe level is roughly $700 \mathrm{MN} / \mathrm{m}^{2}$.

West Burton. Siltstones were found here (Fig. 25), with gypsum bands, and in the relatively unweathered rock $K_{z}=40 \mathrm{MN} / \mathrm{m}^{3}$ at least, which is very similar to that in the Cottam and High Marnham siltstones. Again plate loading tests gave lower $E$ values because of seepage into the pits with consequent weakening.

\section{Summary of modulus profiles-Midlands and Lincolnshire}

In the weathered zone, profiles in mudstone and siltstones are similar (except for isolated higher values in weathered siltstone) with $E_{0}$ at about $4 \mathrm{MN} / \mathrm{m}^{2}$, and $K_{z}$ approximately $4 \mathrm{MN} / \mathrm{m}^{3}$. 


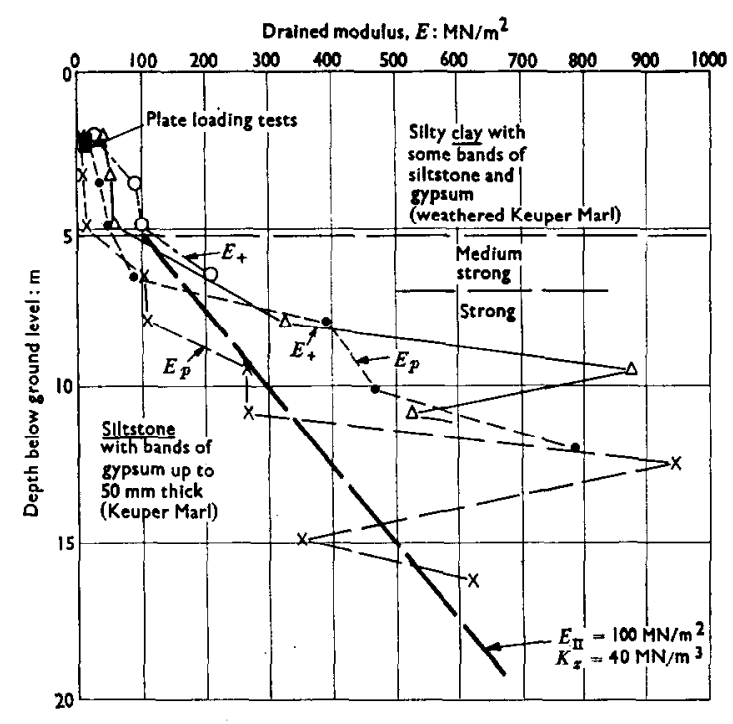

Fig. 25. West Burton

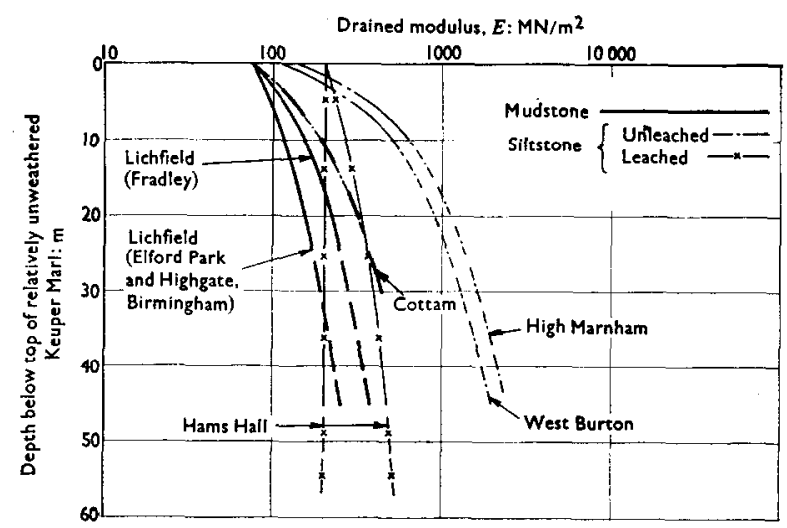

Fig. 26. Modulus profiles in Keuper Marl: Midlands and North-east

The modulus profiles in relativcly unweathered Keuper discussed above are gathered together in Fig. 26, in which they appear as curves because the plot is semi-logarithmic. $K_{z}$ ranges from $5 \mathrm{MN} / \mathrm{m}^{3}$ in the mudstones (Lichfield sites and Highgate, Birmingham) to $40-50 \mathrm{MN} / \mathrm{m}^{3}$ in the siltstones at High Marnham and West Burton. The siltstones at Cottam gave $K_{z}=50 \mathrm{MN} / \mathrm{m}^{3}$, but the silty mudstone profile (shown in Fig. 26) shows $K_{z}=12 \mathrm{MN} / \mathrm{m}^{3}$. The leached siltstone at Hams Hall gave $K_{z}$ ranging from zero to $6 \mathrm{MN} / \mathrm{m}^{3}$.

\section{KEUPER ELSEWHERE}

Redcar (north-east)

The steelworks site at Redcar is also in the western part of the North Sea Basin, but at the extreme northerly end of the Trias onshore outcrop (Figs 1 and 10). It lies on the northern limb of the Redcar dome but on-site dips are from $3^{\circ}$ to $17^{\circ}$ to the south-east. The whole 
Trias succession from Bunter to Rhatic is represented, but the succession is attenuated and possibly confused by folding and faulting.

The Tea Green Marl has a narrow outcrop, and an average thickness a little over $5 \mathrm{~m}$. It ranges from green-grey weak and moderately weak calcareous silty mudstones to moderately weak to moderately strong argillaceous limestones with a small arenaceous content. The rock is moderately jointed with vertical major joints often observed in cores. It is mainly unweathered or slightly weathered with alteration along the joint planes. Modulus values were in the range 500 to $1200 \mathrm{MN} / \mathrm{m}^{2}$, a design value of $1000 \mathrm{MN} / \mathrm{m}^{2}$ being adopted.

The Keuper Marl consists of red-brown with some bands of pale green-grey very weak and weak mudstone, frequently silty, with bands of weak and moderately weak siltstone and argillaceous limestone up to $400 \mathrm{~mm}$ thick.

The Keuper Marl is extensively weathered. It is interspersed with fibrous gypsum forming veins about $1 \mathrm{~mm}$ thick separating angular blocks of mudstone from $10 \mathrm{~mm}$ to $80 \mathrm{~mm}$ across, and in addition zones of gypsum up to $100 \mathrm{~mm}$ thick have been encountered. As weathering has proceeded the gypsum appears to have been leached out leaving a closely fractured rock mass, so that the degree of fracturing reflects the degree of weathering. Redeposition within the weathered zone has resulted in thin sub-horizontal laminae of amorphous gypsum.

The weathering classification adopted is shown in Table 6 . Weathering extended to very variable depths and appeared to be controlled by lithology as well as depth and weathering has extended preferably down-dip in some strata.

From uniaxial and triaxial compression tests, design values of drained modulus of elasticity were selected as shown in Table 6. Plate loading tests were carried out by the Building Research Establishment in boreholes using plates of $865 \mathrm{~mm}$ diameter. From the limited number of results it is not possible to assess, for each category of the Keuper Marl, the mass factor, $j$, which is the ratio between field modulus values from the plate loading tests and laboratory test values. The results suggest however that $j$ is close to unity for both the weathered and unweathered rock.

\section{Runcorn (north-west)}

The site at Runcorn is on a horst between the Manx-Furness Basin and the Cheshire Basin (Fig. 10). It has been much affected by faulting. At one part of the site, where mudstone occurs with bands of siltstone the modulus profile in the relatively unweathered Keuper can be approximately represented by $E_{0}=100 \mathrm{MN} / \mathrm{m}^{2}, K_{z}=50 \mathrm{MN} / \mathrm{m}^{3}$ (Fig. 27). Scatter about this

Table 6. Redcar: weathering classification and selected modulus values in Keuper Marl

\begin{tabular}{|c|c|c|c|}
\hline Category & Weathering & Description of weathering & $\begin{array}{c}\text { Selected value } \\
\text { of drained } \\
\text { modulus } E \\
\mathrm{MN} / \mathrm{m}^{2}\end{array}$ \\
\hline A & Completely weathered & No lithorelicts, reduced to silty clay & - \\
\hline $\mathbf{B}$ & Highly wcathered & Large amount of matrix & 50 \\
\hline $\mathrm{C}$ & Moderately weathered & Small amount of matrix; no gypsum & 200 \\
\hline D & Slightly weathered & Slightly gypsiferous, i.e. $<5 \%$; some leaching & 1000 \\
\hline $\mathrm{E}$ & Unweathered & $\begin{array}{l}\text { Highly gypsiferous }(>40 \%) \text {, and moderately } \\
\text { gypsiferous }(5-40 \%) ; \text { no leaching }\end{array}$ & 3000 \\
\hline
\end{tabular}


profile is large, and it would appear likely that the lower values relate to the occurrence of mudstone.

Nearby, faulting has produced sandstone down to about $10 \mathrm{~m}$, which brings modulus values an order higher (Fig. 28).

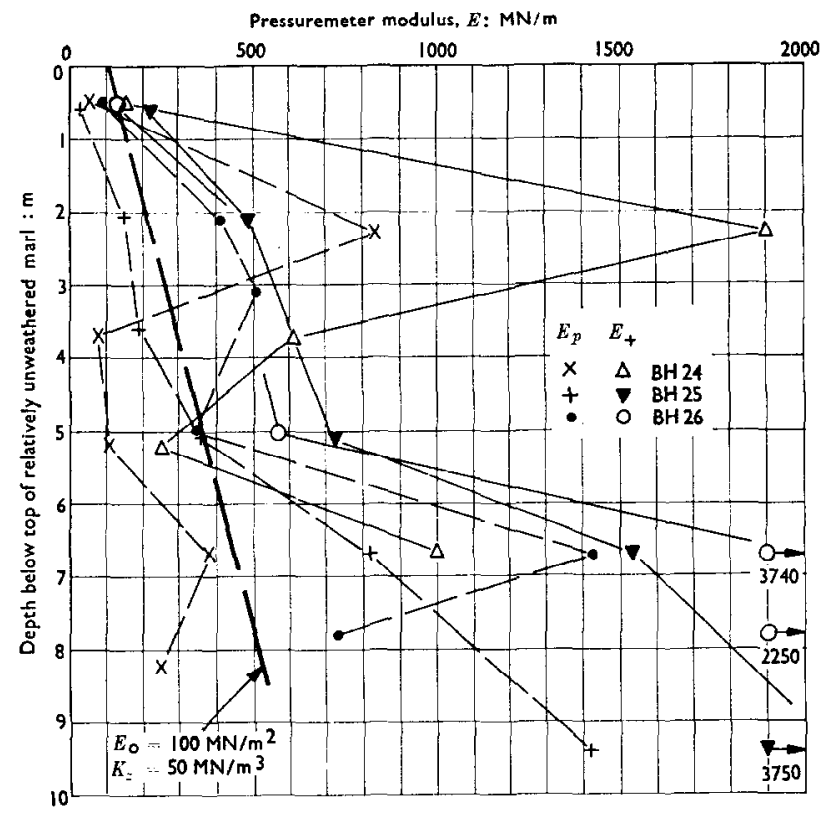

Fig. 27. Runcorn: mudstone with bands of siltstone

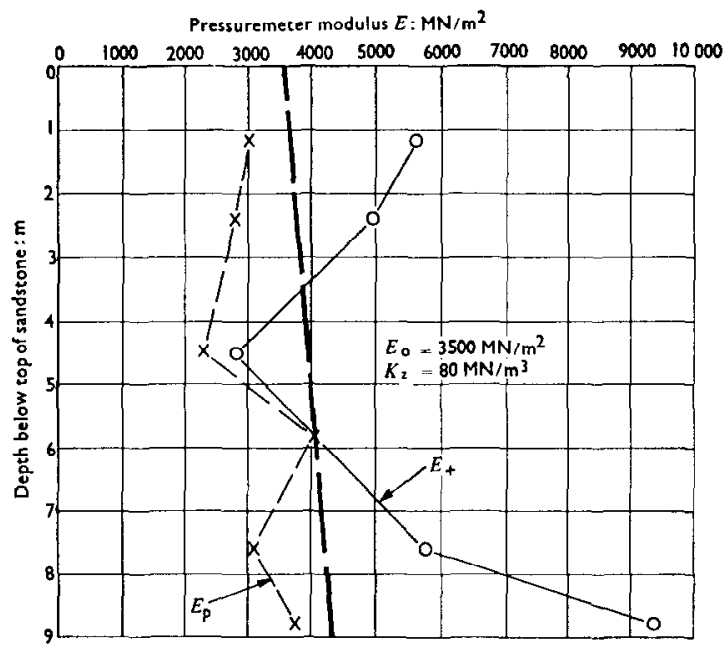

Fig. 28. Runcorn: sandstone 



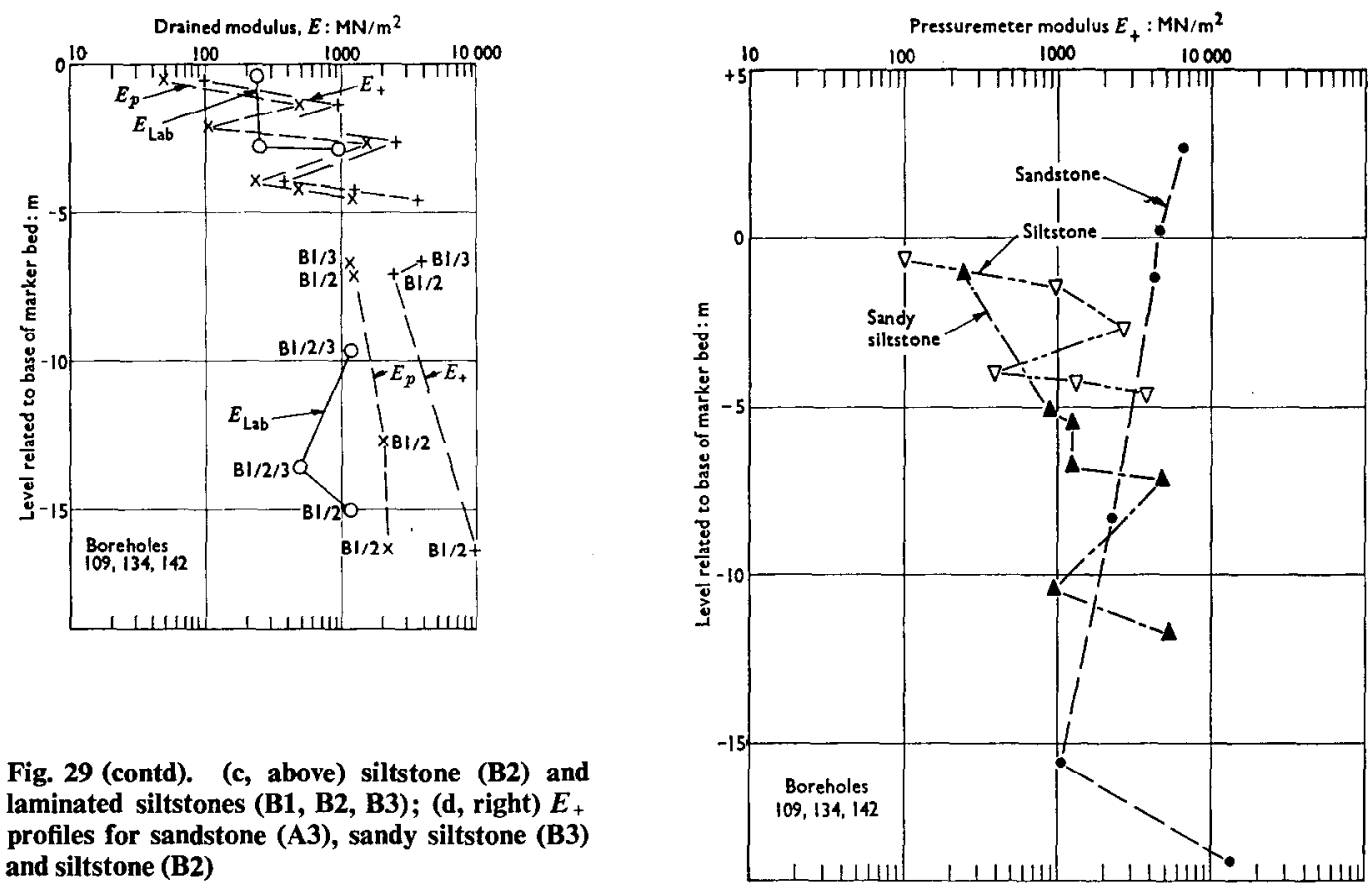

Fig. 29 (contd). (c, above) siltstone (B2) and laminated siltstones (B1, B2, B3); (d, right) $E_{+}$ profiles for sandstone (A3), sandy siltstone (B3) and siltstone (B2)

\section{Portskewett (south-west)}

The proposed power station site at Portskewett is marginal to the Bristol Channel Basin or to an arm of it, possibly connecting it to the Worcester Graben (Fig. 10). The Keuper rocks are predominantly arenaceous, consisting of thin varied facies over Dolomitic Conglomerate and Carboniferous limestone and mudstone. They are near the top of the Keuper Marl. The Dolomitic Conglomerate is diachronous, occurring late in this area as it often does elsewhere. Fig. 29 combines the results of pressuremeter tests and laboratory modulus tests from three boreholes. Fig. 29(a) gives results of tests only on unweathered sandstone (A3) with an average moisture content about $5 \%$, showing close agreement between laboratory $E$ values and $E_{+}$values from the pressuremeter tests. Fig. 29(b) shows results only for the sandy siltstone (B3) similar to the sandstone, with an average moisture content of about $6 \%$, and Fig. 29(c) shows, at higher levels, results for siltstone (B2) with an average moisture content about $8 \cdot 5 \%$, and at lower levels results for siltstones laminated with weak argillaceous siltstone (B1) and sandy siltstone (B3) grading into sandstone (A3). In these laminated materials the laboratory $E$ values fall well short of the pressuremeter values $E_{+}$and $E_{\mathrm{p}}$. This would appear to indicate both stress relief effects on the laboratory test results and the anisotropic stiffening effect of the laminations on the pressuremeter test results.

In Fig. 29(d) profiles are shown based on $E_{+}$values for the sandstone (A3), the sandy siltstone (B3) and the siltstone (B2). Reduction of modulus values due to weathering of the more argillaceous materials below the sandstone capping can be seen. Below this zone, the modulus values in all the materials are high compared with modulus values in the siltstones in Lincolnshire and in the marginal facies at the M1 bridges' sites near Loughborough. The cementing material for the sandstone (A3) at Portskewett was found to be dolomite, with some 
calcite, and although the cementing materials for the siltstones were not determined it is possible that these were also dolomitic. The M1 bridge sites' siltstones on the other hand were cemented with carbonate (mainly calcite) and some clay minerals, together with iron oxide in some specimens.

\section{BUNTER AND RHAETIC}

The discussion so far has all been about Keuper. The outcrop of the Rhaetic is thin, and it does not appear to have been investigated in relation to any noteworthy foundation problems, so that there is little information available concerning its drained modulus of elasticity. At the Redcar site referred to earlier, the Rhaetic is present in the form of the Cottam Beds and the Westbury Beds, with a narrow outcrop and an average total thickness of about $10 \mathrm{~m}$. The Cottam Beds consist of closely fractured very weak mudstone with occasional thin laminae of siltstone. At outcrop the mudstone is highly to moderately weathered, partly reducing it to clay, but where it is overlain by the Lower Lias it is slightly weathered with alteration only along the fractures. The Westbury Beds consist of poorly and thinly laminated calcareous sandy silty very weak mudstone with fine- and medium-grained weak and moderately weak sandstone bands up to $200 \mathrm{~mm}$ thick. The unweathered Westbury Beds are moderately fractured and jointing is well developed. Moderate weathering partially reduces the mudstone to a brown sandy silt and this zone extends up to $3 \mathrm{~m}$ into the rock. Modulus values were between $100 \mathrm{MN} / \mathrm{m}^{2}$ and $200 \mathrm{MN} / \mathrm{m}^{2}$.

The Bunter is much less variable than the Keuper, with modulus values generally in the range $1000 \mathrm{MN} / \mathrm{m}^{2}$ at rockhead, increasing to about $3000 \mathrm{MN} / \mathrm{m}^{2}$ some $12 \mathrm{~m}$ below. This means that settlement is seldom a problem, except where high loads and pressures are concerned or there are exceptional requirements concerning limitation of settlement.

At the Hartlepool Nuclear Power Station site, the top $20 \mathrm{~m}$ or so of the Bunter, below some $30 \mathrm{~m}$ of glacial drift, had lower laboratory $E$ values, in the range $250 \mathrm{MN} / \mathrm{m}^{2}$ to $750 \mathrm{MN} / \mathrm{m}^{2}$. This rock is in the upper part of the Upper Mottled Sandstone, and the top $20 \mathrm{~m}$, close to the Keuper, consists of siltstones, mudstones, and fine sandstones. The reduced $E$ values probably result from weathering of the more argillaceous components. Below the top $20 \mathrm{~m}$ there is typical cross-bedded Bunter Sandstone.

Lower $E$ values were also measured at Stourport (Fig. 9), where the Bunter was very weakly cemented.

\section{MAJOR CASE HISTORIES}

The sites of the major case histories to be presented are nuclear power station sites at Heysham (Bunter) and Oldbury (Keuper), and an office block site at Cardiff (Keuper). The investigation for Oldbury A-Station was done in 1959 and 1960; construction took place between 1962 and 1965; the B-Station investigation was done in 1970. The Heysham investigation was done in 1967, after Oldbury A. It was planned and carried out in the knowledge of the difficulties which occurred with Oldbury A. Cardiff came later.

\section{HEYSHAM}

The Heysham site is on the eastern margin of the Manx-Furness Basin. A preliminary investigation in 1966 revealed made ground and shore deposits (mainly sand), some thin Boulder clay and then the Upper Mottled Sandstone of the Bunter. On the site the Bunter is faulted against the Millstone Grit of the Carboniferous.

The sandstone is fine- and medium-grained, the coarser grains being sub-angular to rounded, becoming increasingly angular with decreasing size. Cementing agents are iron oxide, with 


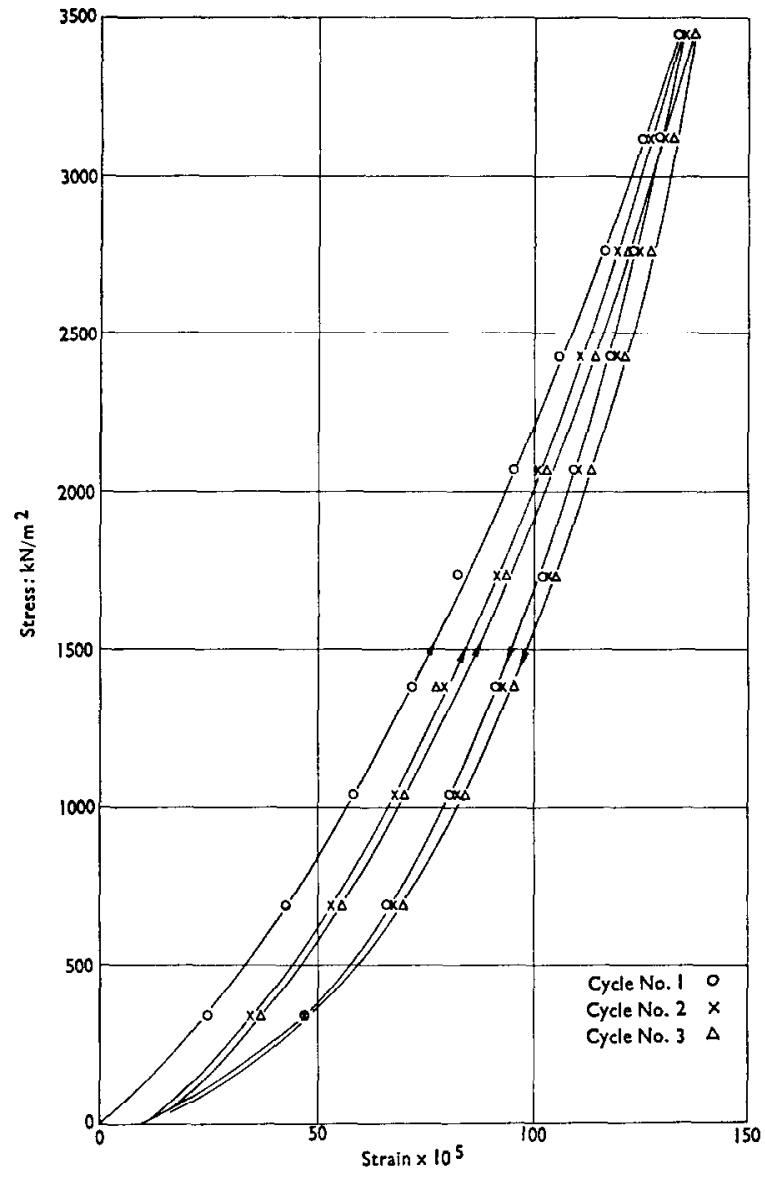

Fig. 30. Heysham: typical laboratory test stress-strain curve

clay minerals, and some authigenic silica. There are mudstone partings within the sandstone, and in one borehole a mudstone layer nearly $50 \mathrm{~mm}$ thick was found. Mudstone flakes and pellets are disseminated throughout the sandstone. The weathered zone, generally up to one metre thick, although locally thicker, consists of uncemented sand, apparently reworked by glacial action.

The main site investigation, done in 1967, had as principal objectives the determination of rockhead contours, the evaluation of deformation characteristics of the bedrock, and the assessment of its permeability in connexion with excavation below the water table and the construction of cooling-water tunnels.

Plate loading tests were carried out to establish the drained modulus of elasticity, $E$, and laboratory tests on rock cores were done to determine the variability of $E$ in depth and across the site. A typical laboratory stress-strain curve (Fig. 30) shows a non-linear relationship, the tangent modulus increasing with increasing strain, which is a feature of the Bunter at Heysham and at a number of other sites. For purposes of comparison, secant moduli were evaluated to an axial stress of $1400 \mathrm{kN} / \mathrm{m}^{2}$. Resulting values of the modulus $\left(E_{\mathrm{sec} 1400}\right)$ for 


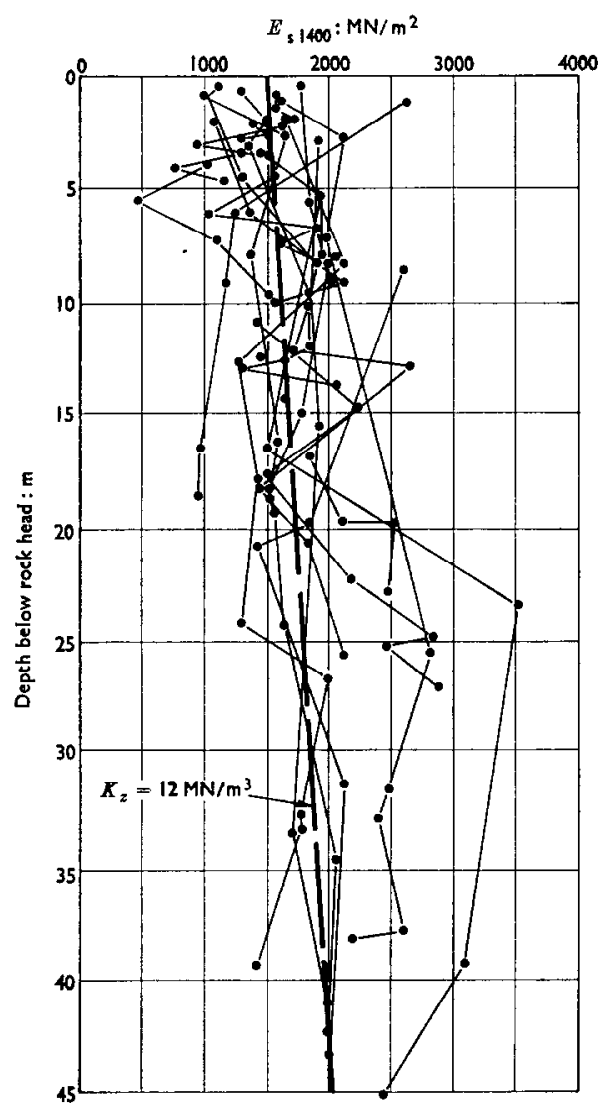

Fig. 31. Heysham: laboratory test modulus (secant to $1400 \mathrm{kN} / \mathrm{m}^{2}$ )

the whole site are plotted against depth below rockhead in Fig. 31, on which has been drawn a representative modulus profile with the parameters $E_{0}=1500 \mathrm{MN} / \mathrm{m}^{2}, K_{z}=12 \mathrm{MN} / \mathrm{m}^{3}$.

Plate loading tests were done in the main foundation area on $600 \mathrm{~mm}$ diameter plates at three levels in a $19 \mathrm{~m}$ deep shaft. Deep wells surrounding the shaft were pumped to determine the drawdown characteristics and permeability of the sandstone and also to control the water levels prior to excavation within the shaft to avoid disturbance from uplift and seepage forces during excavation and during the loading tests. Fine control of water lcvel, to plate level, was achieved by additional pumping from an internal sump. The load-settlement curve for a test about $7 \mathrm{~m}$ below rockhead is shown in Fig. 32. The non-linear stress-strain response can again be seen. Such plate loading tests are expensive, and increasingly expensive if larger diameter plates are used, which is desirable in order that the results may fully include the effects of bedding and joints in the rock. Plate loading tests were therefore also carried out away from the main loading area, at a position where rockhead was nearer to the surface. Groundwater levels were controlled by a system of well-points within the overburden and within bedrock. The tests were done at two levels, on plates of $600 \mathrm{~mm}$ diameter and $1500 \mathrm{~mm}$ diameter at each level, one of the larger diameter tests being continued, at constant load, for nearly four months to determine creep characteristics (Meigh et al., 1973). 


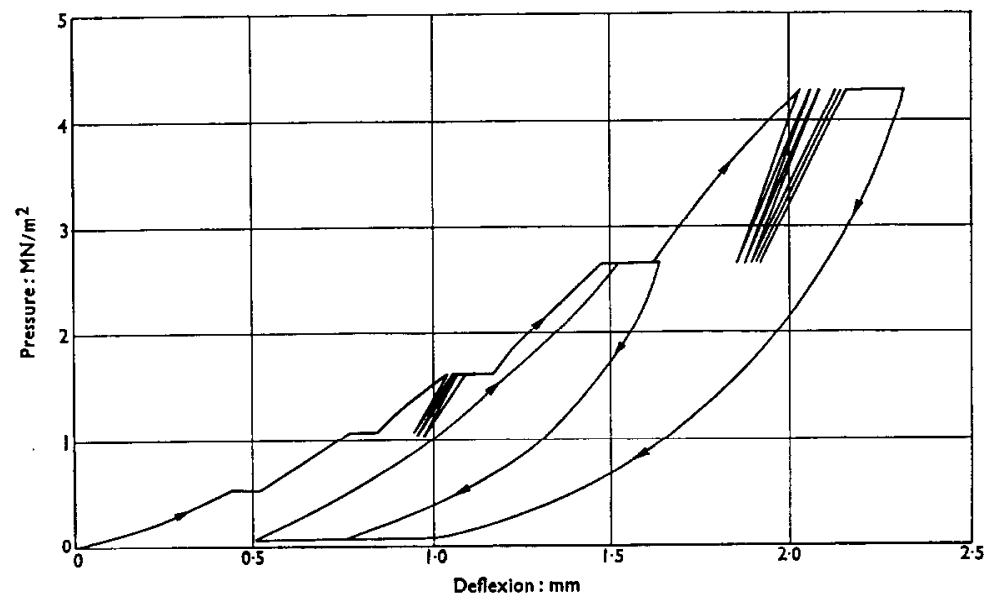

Fig. 32. Heysham: typical plate loading test pressure-deflexion plot

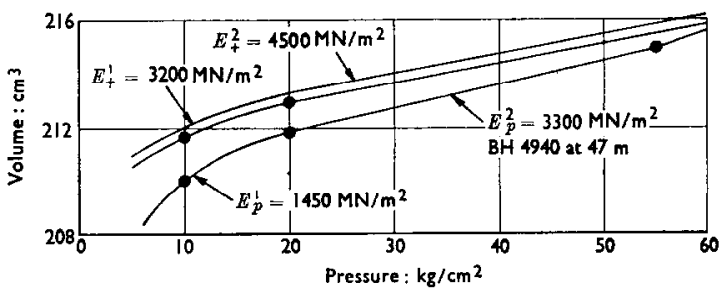

Fig. 33. Heysham: typical pressuremeter test

Results of the plate loading tests were correlated with results of laboratory tests on cores from boreholes put down close to the plate test positions and from these results values were determined of the mass factor, $j$, defined as the ratio of field modulus to laboratory test modulus, and representing the effect of rock discontinuities. The average value of $j$ was found to be 0.83 .

Pressuremeter tests in drill-holes were also used to give a measure of variability of $E$, and correlated with plate loading test values. As with the laboratory and plate loading tests, the modulus was measured on the reloading cycle. A non-linear pressure-volume curve was obtained (Fig. 33). The results of laboratory tests from the vicinity of the pressuremeter tests are given in Fig. 34 and the corresponding pressuremeter test results in Fig. 35. To aid comparison, the modulus profile $E_{0}=1500 \mathrm{MN} / \mathrm{m}^{2}, K_{z}=12 \mathrm{MN} / \mathrm{m}^{3}$ has been drawn on Figs 34 and 35 . On this site the modulus values from the laboratory tests were found to be more useful than the pressuremeter tests for correlation with the plate loading test results.

At the planning stage, two possible foundation arrangements were considered for the reactor foundations with a total load of $450 \mathrm{MN}$, one with a foundation diameter of $27.4 \mathrm{~m}$ and a pressure of $860 \mathrm{kN} / \mathrm{m}^{2}$ and the other with a pressure of $1930 \mathrm{kN} / \mathrm{m}^{2}$ and a correspondingly smaller diameter. The final design arrangement was closer to the lower pressure version, with 
a diameter of $25.2 \mathrm{~m}$ and a gross foundation pressure of $830 \mathrm{kN} / \mathrm{m}^{2}$. Load-time-settlement plots to date are given in Fig. 36. There have been difficulties in measuring heave with consequent uncertainties in the earlier stages of the settlement plots. However, it is believed that subsequent observations are reliable although not to a high degree of accuracy. Loadsettlement plots are given in Fig. 37, together with calculated final settlements estimated at the planning stage, excluding creep, and adjusted to the design loadings. Prediction (a), based

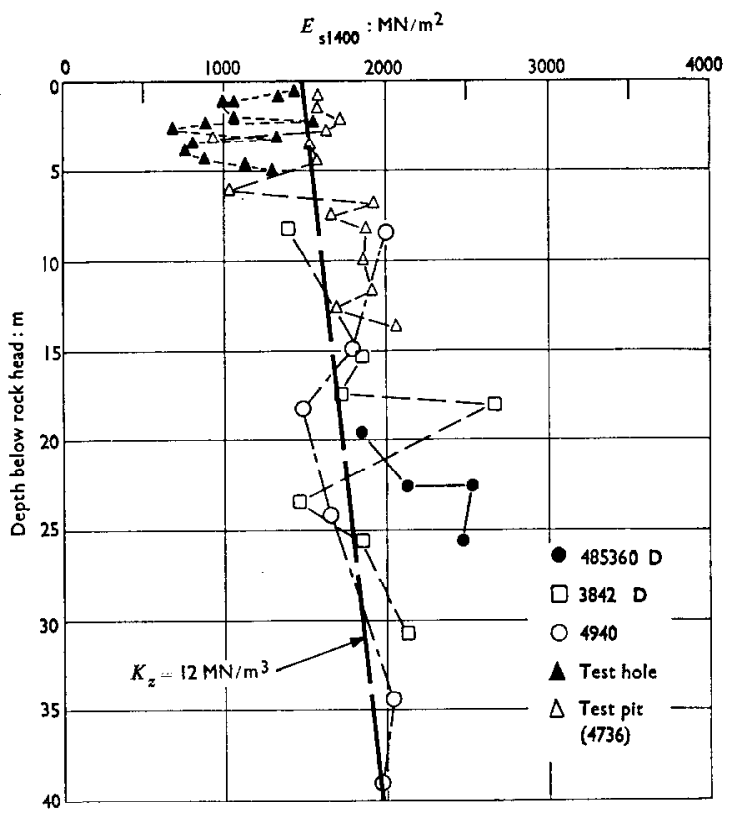

Fig. 34. Heysham: laboratory test modulus (secant to $1400 \mathrm{kN} / \mathrm{m}^{2}$ ) from vicinity of pressuremeter tests

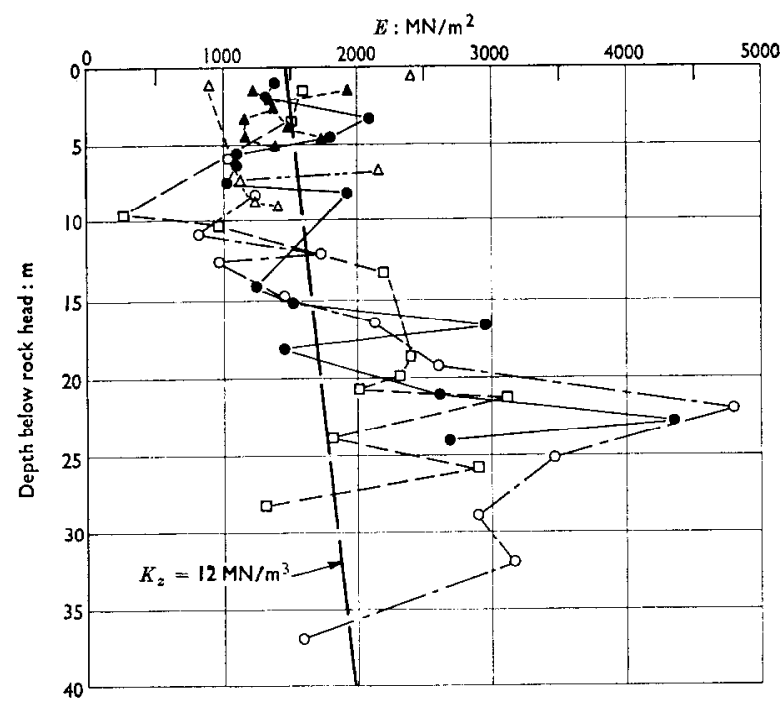

Fig. 35 Heysham: modulus from pressuremeter tests 
on a uniform half-space, constant modulus, $E=1500 \mathrm{MN} / \mathrm{m}^{2}$ and $j=0.83$, gave $17 \mathrm{~mm}$. Prediction $(b)$, based on a stepped modulus profile, with $E=1030 \mathrm{MN} / \mathrm{m}^{2}(j=0.83)$ from $0 \mathrm{~m}$ to $6 \mathrm{~m}$ below foundation level and $E=1720 \mathrm{MN} / \mathrm{m}^{2}(j=1 \cdot 0)$ below $6 \mathrm{~m}$, gave $13 \mathrm{~mm}$. A subsequent calculation has been made using the representative profile $E_{0}=1500 \mathrm{MN} / \mathrm{m}^{2}$, $K_{z}=12 \mathrm{MN} / \mathrm{m}^{3}$, based on the laboratory secant modulus values to a stress of $1400 \mathrm{kN} / \mathrm{m}^{2}$, but reduced to $E_{0}=1300 \mathrm{MN} / \mathrm{m}^{2}, K_{z}=10 \mathrm{MN} / \mathrm{m}^{3}$ to allow for the reduced foundation pressure.

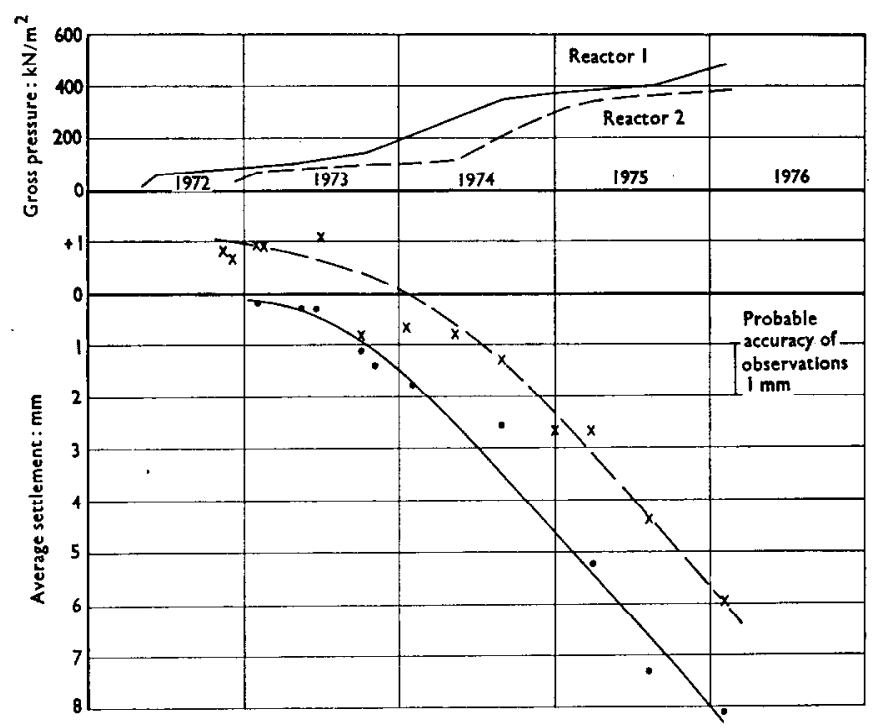

Fig. 36. Heysham: settlement-load-time records for reactors 1 and 2

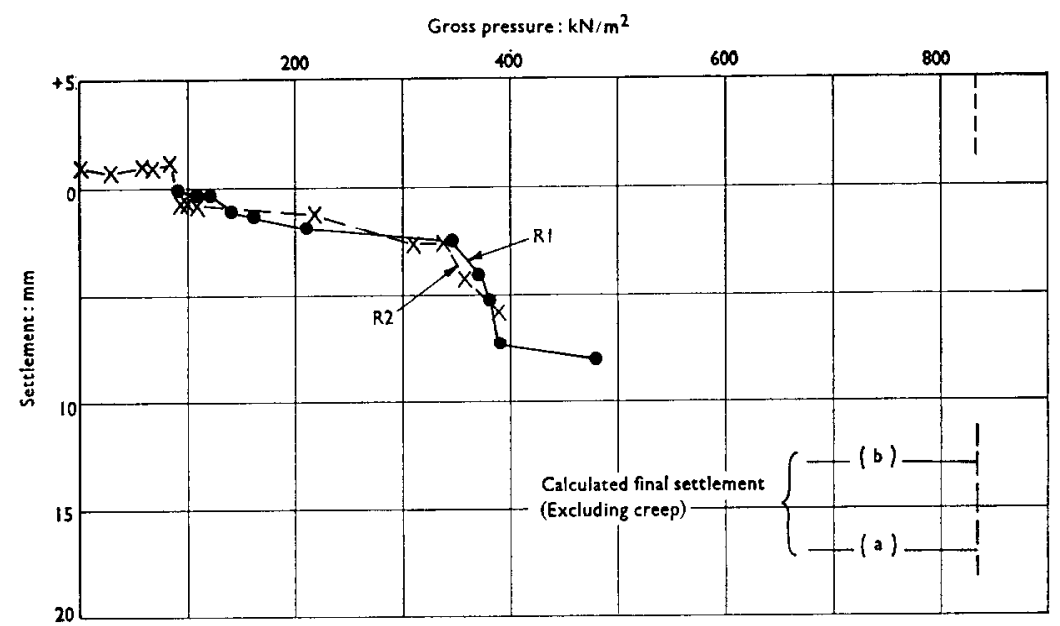

Fig. 37. Settlement of Heysham reactors 

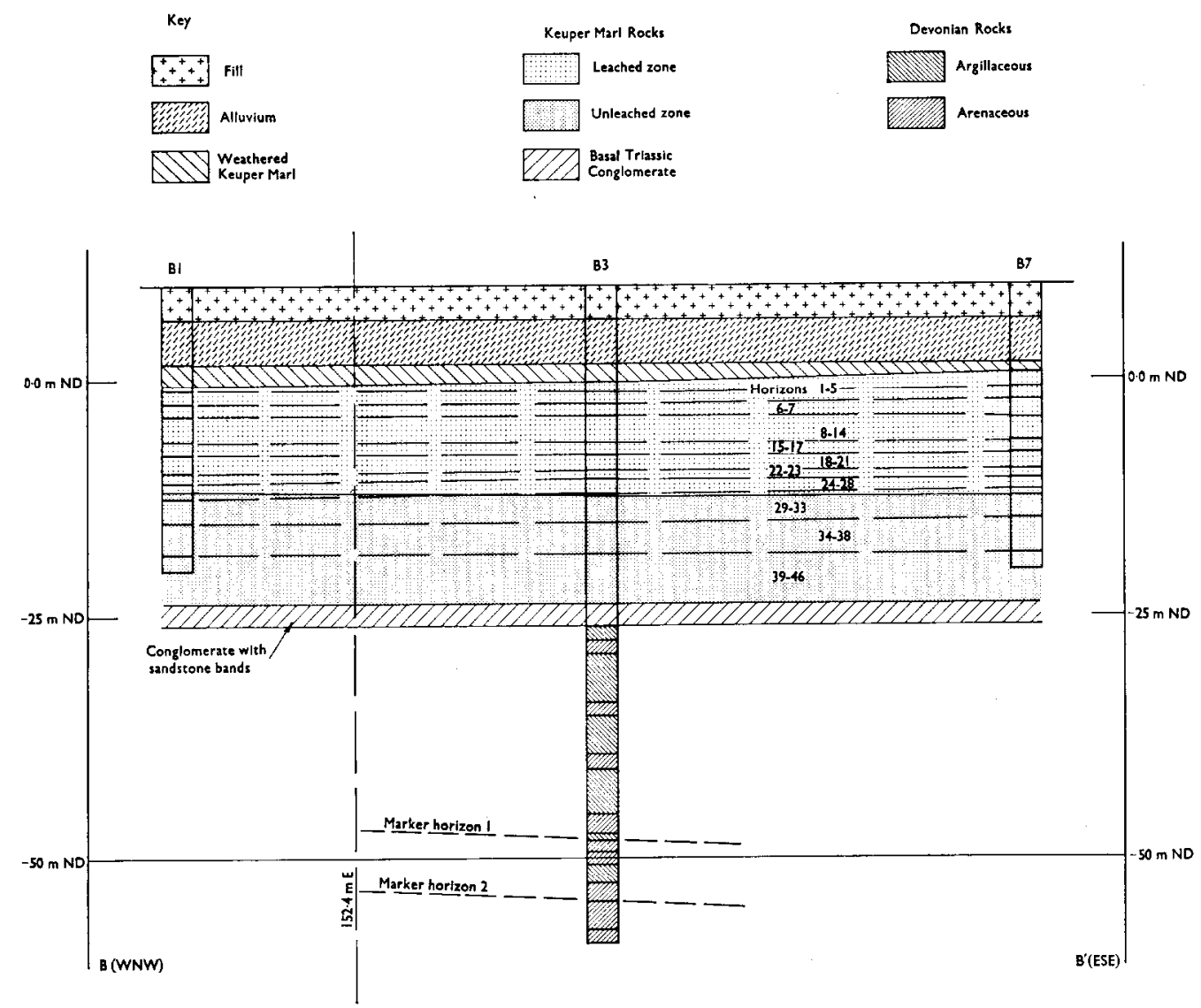

Fig. 38. Oldbury B

The mass factor, $j$, was taken as $\mathbf{0 \cdot 8 3}$. The calculation has been done by the method outlined earlier, and gives a final settlement, excluding creep, of $11 \mathrm{~mm}$. Hobbs (1973) presented a method of calculation which takes the effects of non-linearity more fully into account. Using it in this case also leads to a calculated settlement (excluding creep) of $11 \mathrm{~mm}$.

Settlement to date, at about half-load, amounts to about $8 \mathrm{~mm}$. This will include some creep, since loading has extended over some three years, out of a total expected creep of about $9 \mathrm{~mm}$. It seems therefore that there will be reasonable correspondence between calculated and observed settlement.

\section{OLDBURÝ}

The Oldbury Nuclear Power Station site is on the south-eastern side of the Severn Estuary, some $20 \mathrm{~km}$ north of Bristol, and $4 \mathrm{~km}$ upstream of Aust Cliff, a well-known exposure of the Keuper. The site appears to be a shallow local basin, or an arm of the Bristol Channel Basin (Fig. 10). The total Keuper succession is thin. At Aust Cliff, below $7 \mathrm{~m}$ of Rhaetic, it amounts to $28 \mathrm{~m}$, including $3 \mathrm{~m}$ of Tea Green Marl and $2 \mathrm{~m}$ of basal conglomerate. 


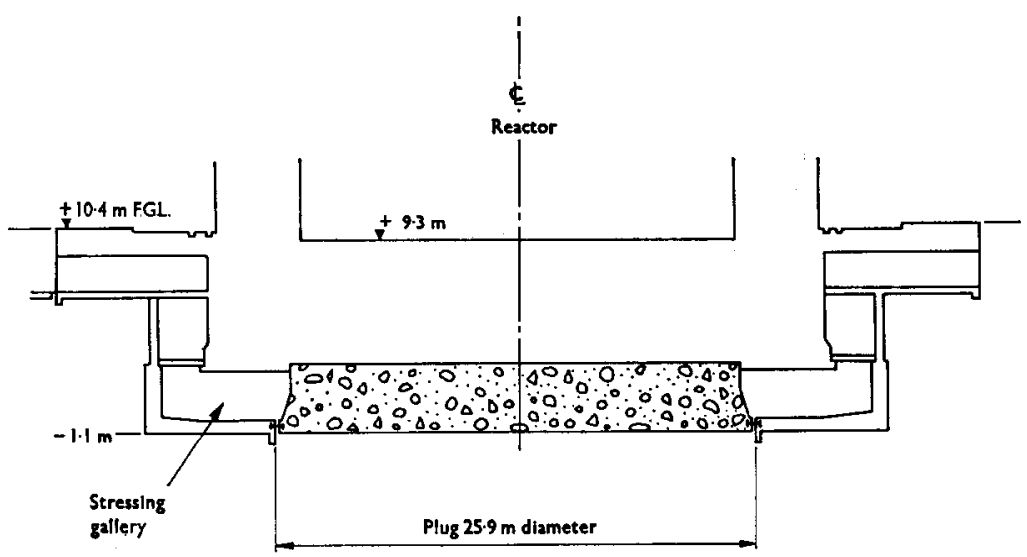

Fig. 39. Oldbury A: section through reactor building

The site investigation for the A-Station was done in 1959 , and grouting and pumping trials were made in 1960. A further site investigation on behalf of one of the tenderers for the construction was done between December 1960 and February 1961. Although the grouting trials were useful, neither of the site investigations would be considered adequate by modern standards. However, they revealed a succession of thinly-bedded interbedded Keuper sandstones, siltstones and argillaceous siltstones, followed by a basal conglomerate lying unconformably on Devonian sandstones and siltstones. The succession is remarkably uniform across the site, as shown in Fig. 38, a cross-section through part of the B-Station site, which is almost identical to that across the $\Lambda$-Station site.

Natural ground level was at about $+6.5 \mathrm{~m} \mathrm{ND}$, subsequently made up to $+11 \mathrm{~m} \mathrm{ND}$. Below ground level was some $4 \mathrm{~m}$ of recent alluvium consisting of soft clay and peat, followed by about $2.5 \mathrm{~m}$ of weathered Keuper Marl. Below this the Keuper consisted of an upper leached zone about $13 \mathrm{~m}$ thick and a lower unleached zone about $10 \mathrm{~m}$ thick. The leaching could clearly be seen in the sandstones where gypsum nodules occur in the unleached zone and corresponding cavities in the leached zone. The cavitated horizons in the sandstones of the leached zone were interconnected forming aquifers of very high permeability.

Construction started in 1962 with excavation for the two reactor foundations within grouted cut-off walls forming a series of boxes around the various main foundations. The reactors were founded on concrete plugs at about $-1 \mathrm{~m} \mathrm{ND}$, these being surrounded by stressing galleries, as shown in Fig. 39. Total load per reactor is $680 \mathrm{MN}$, at a gross pressure of $1265 \mathrm{kN} / \mathrm{m}^{2}$, about $1100 \mathrm{kN} / \mathrm{m}^{2}$ net. Significant loading began in mid-1963 for Reactor 1 (R1) and towards the end of 1963 for R2. It was expected that total settlement would be less than $60 \mathrm{~mm}$; the calculated value was $40 \mathrm{~mm}$.

When the foundations for R2 were opened up to final level, which was at a lower level stratigraphically than R1, cavities in the sandstone in horizon 3 (see Fig. 45) were bigger than had previously been found. Plate loading tests were therefore carried out to check that there was an adequate factor of safety against collapse of the cavitated zone.

By early 1965 , with about $90 \%$ of total load applied, settlements had already exceeded $60 \mathrm{~mm}$ (Figs 40 and 41). Furthermore, they were increasing under virtually constant load. This was obviously not consolidation, because of the relatively high permeability and the short 
drainage paths, and it was clear that creep was taking place. The rate at this time was about one millemetre per month.

Further exploration was done towards the end of 1966. This included drilling to check the ground conditions, the drilling of holes from the stressing galleries for an endoscope survey, with particular attention to the cavitated sandstones, and the installation of vertical movement gauges consisting of Invar rods in drilled holes, anchored into rock at their lower ends, and fitted with micrometer measuring devices at their upper ends to measure movement relative to the reactor foundation. Some gauges had deep refercnce points, at $-27 \mathrm{~m} \mathrm{ND}$, to measure compression of all the Keuper below foundation level. Others had shallow reference points, at $-15 \mathrm{~m} \mathrm{ND}$, to measure compression of the leached zone. Readings were taken day and night over several months. A short section of the compression plot, for one deep reference

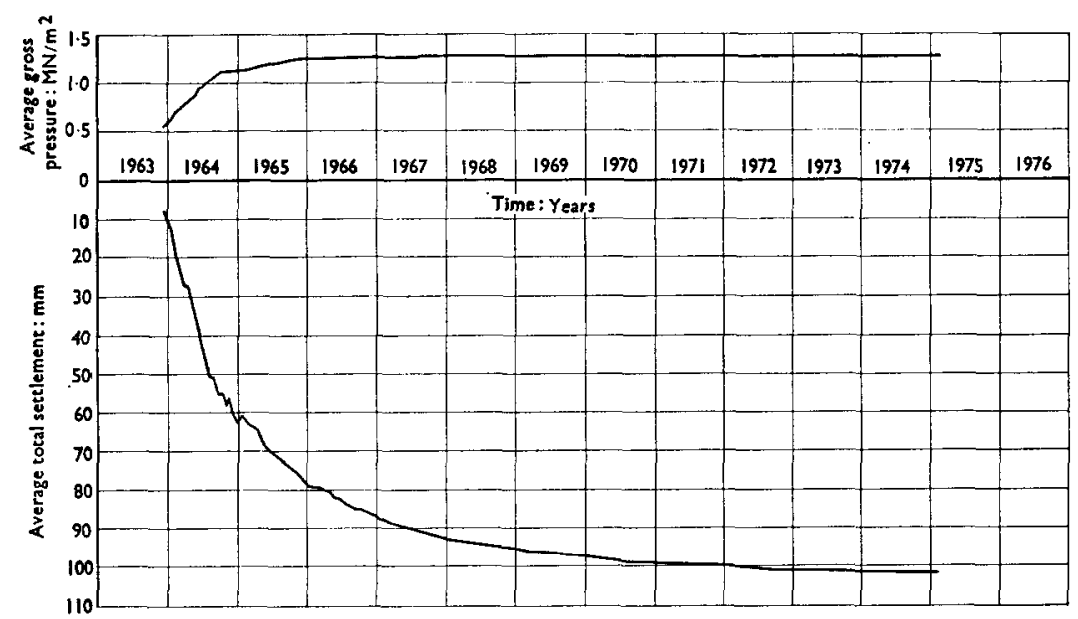

Fig. 40. Oldbury $\Lambda$ : pressure vessel settlement for reactor 1

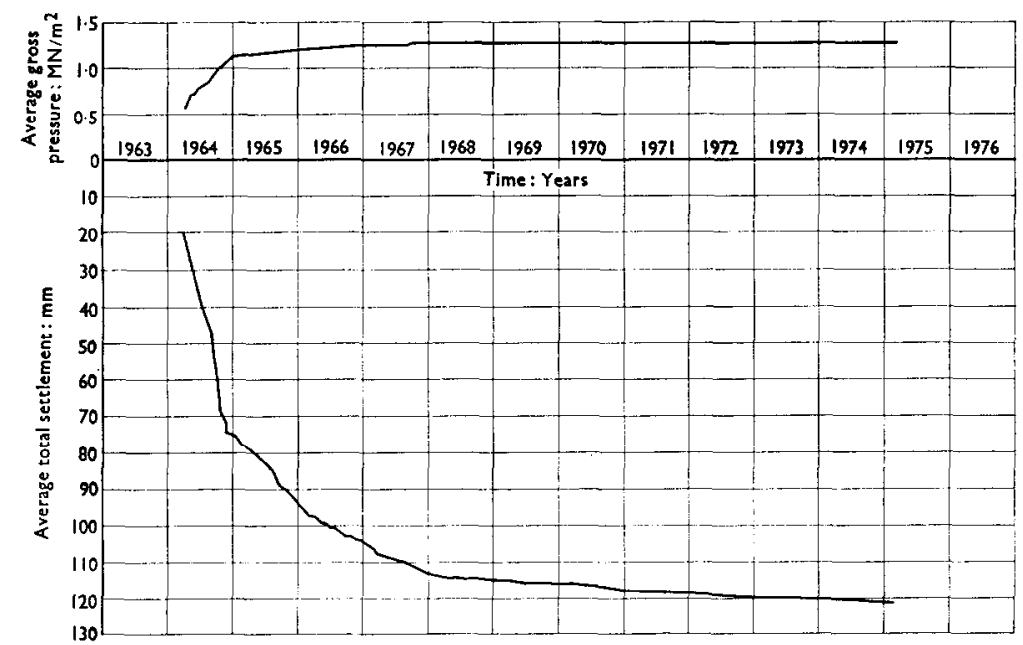

Fig. 41. Oldbury A: pressure vessel settlement for reactor 2 


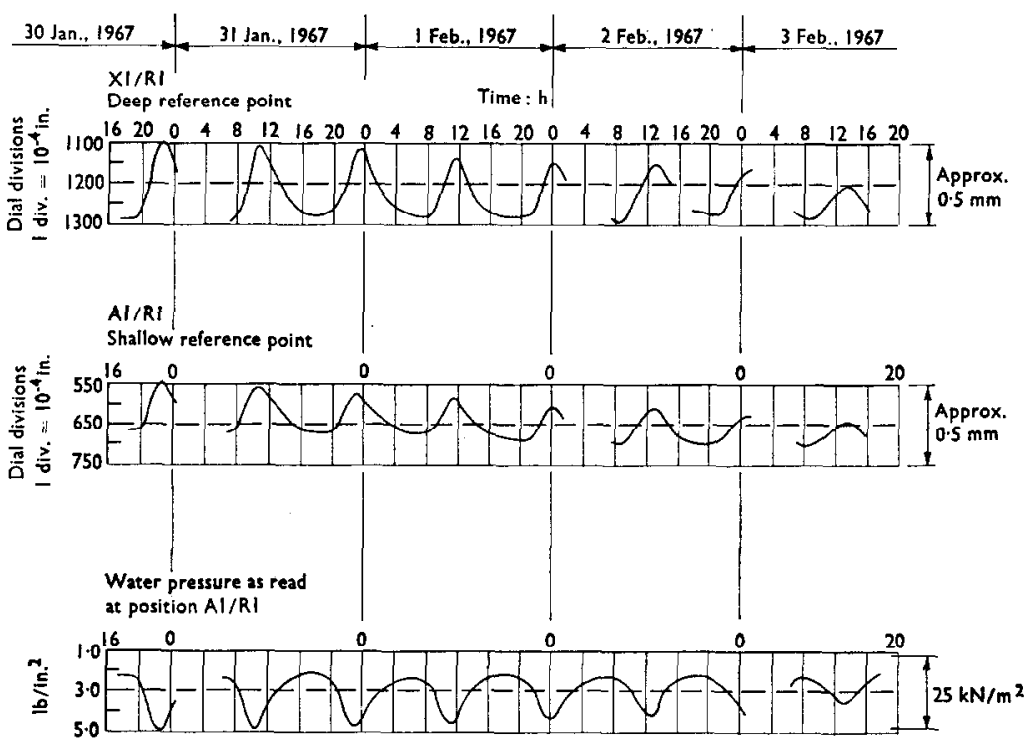

Fig. 42. Oldbury A, reactor 1 : plot of field data (extract from master plot of vertical movement indicators)
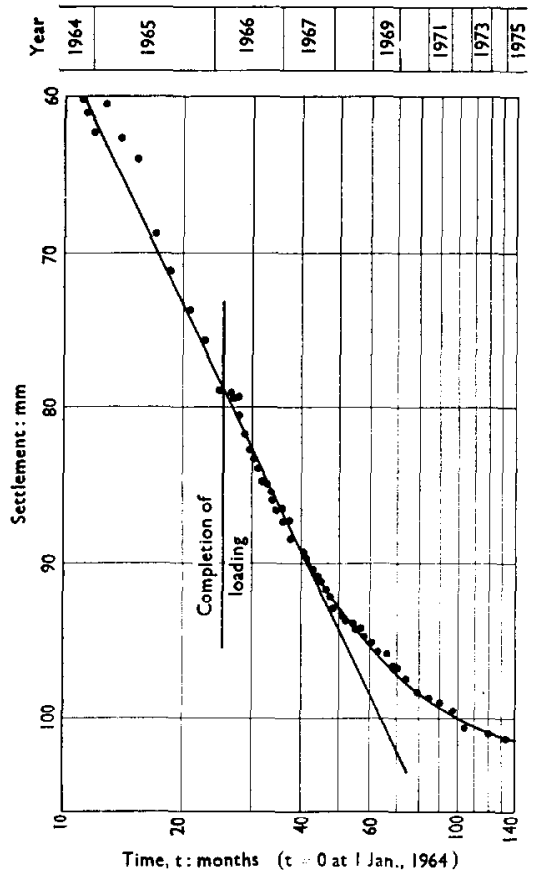

Fig. 43. Oldbury $A$, reactor 1 : settlement against log time
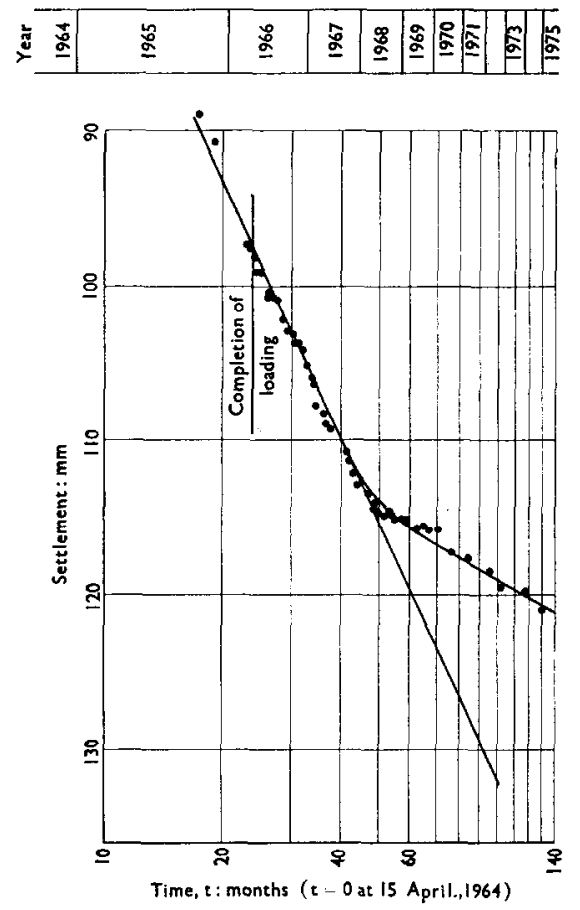

Fig. 44. Oldbury $A$, reactor 2: settlement against log time 


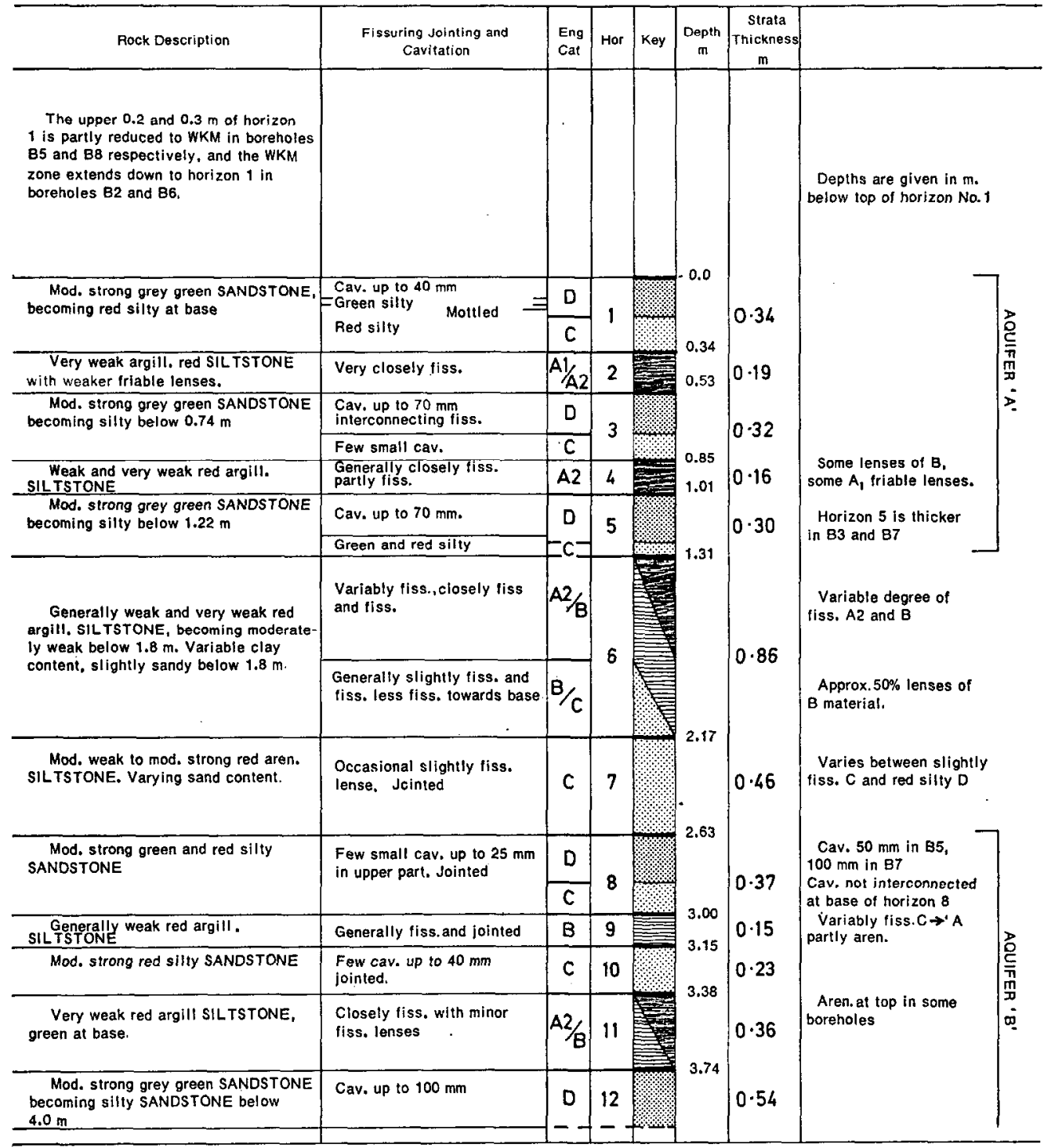

Fig. 45. Oldbury B: part of master log for Keuper Marl horizons

Table 7. Oldbury : Keuper Marl-brief descriptions

\begin{tabular}{|c|c|}
\hline Category & Brief description \\
\hline $\begin{array}{l}\text { WKM } \\
\left.\begin{array}{c}\mathrm{A}_{1} / \mathbf{A}_{2} \\
\mathrm{~A}_{2} \\
\mathbf{B} \\
\mathbf{C} \\
\mathbf{D}\end{array}\right\}\end{array}$ & $\begin{array}{l}\text { Weathered Keuper Marl } \\
\text { Very weak, closely fissured, argillaceous Siltstone } \\
\text { Weak, fissured, argillaceous, Siltstone } \\
\text { Moderately weak to moderately strong, very silty, fine-grained Sandstone or sandy Siltstone } \\
\text { Moderately strong, fine-grained Sandstone }\end{array}$ \\
\hline
\end{tabular}


point and one shallow reference point, is given in Fig. 42. Also plotted are changes of water pressure within the foundation zone, showing the effect of tidal variation in the River Severn. This tidal variation in water pressure produced a corresponding variation in the movements of the foundation, as can be seen in Fig. 42. However, a progressive trend of downward movement can also be discerned. The movement was taking place almost entirely in the leached zone. The rate of creep at this time, as shown by the movement gauges and by the continuing settlement measurements, was about $0.65 \mathrm{~mm} /$ month for $\mathrm{R} 1$ and $0.85 \mathrm{~mm} / \mathrm{month}$ for $\mathrm{R} 2$. The average rate of creep, $0.75 \mathrm{~mm} /$ month may not seem large, but at this stage it was not clear whether it was progressing linearly, or at a reducing rate; $0.75 \mathrm{~mm} / \mathrm{month}$ for 30 years amounts to $270 \mathrm{~mm}$. Much important equipment is carried on beams spanning between the reactors and adjacent structures on piled foundations. Large differential settlements between the reactors and the adjacent structures could have created serious problems for these beams and the equipment carried by them. Fortunately tilt was small. The differences of settlement across reactor foundation reached maximum values of $13 \mathrm{~mm}$ and $10 \mathrm{~mm}$, for R1 and R2 respectively, by the end of loading, and have thereafter remained constant.

Laboratory creep tests were undertaken and these showed creep in all the Keuper materials. Attempts were made to estimate long-term creep settlement by a synthesis of the laboratory test data and also by mathematical extrapolation of the settlement-time curves using a variety of theoretical creep-time relationships (for example, power law relationships). One method of extrapolation, by far the simplest, was by linear extrapolation on a settlement-log time plot (Figs 43 and 44). It will be seen that in 1968 the settlement began to diverge from the straightline on the semi-log plot. In 1975, at the last available settlement readings, the rate of settlement was down to about $0.5 \mathrm{~mm} /$ year for $\mathrm{R} 1$ and $0.7 \mathrm{~mm} /$ year for $\mathrm{R} 2$. A straight-line continuation on the semi-log plot would indicate further settlement amounting to $5 \mathrm{~mm}$ or less in the next 20 years.

Investigation for the Oldbury B-Station was done in the latter part of 1970, with laboratory testing and reporting continuing into early 1971. This gave a great opportunity to investigate in detail the deformation characteristics of the various rock types present. It was decided not to undertake plate loading tests as they would have been extremely costly in view of the groundwater conditions and since the A-Station could be regarded as a massive trial loading for the B-Station. The evaluation of $E$ values was therefore based on laboratory tests. The succession was found to be identical with that on the A-Station site, with only minor differences in the degree of weathering in the upper levels. In the Keuper Marl, forty-six distinct horizons below the weathered zone were identified and correlated between boreholes. This enabled a master $\log$ to be drawn up based on the average thickness of these horizons. Part of this master log is shown in Fig. 45.

The Keuper rocks were divided into engineering categories as shown in Table 7. Laboratory tests for drained modulus of elasticity, $E$, consisted of oedometer tests, Rowe cell tests and triaxial compression tests on the weaker materials, and uniaxial and triaxial compression tests on the stronger materials. Where possible, triaxial tests were done on specimens with a length greater than their diameter (up to twice the diameter) but in a few cases slightly shorter spccimens were used. Both short- and long-duration loading periods were used, the short periods being of 10 minutes duration and taken as 'undrained'. It was found that a loading period of about four hours was long enough to eliminate any build-up of pore-pressure, so this period was adopted for determination of drained modulus. Examples of stress-strain curves are given in Figs 46-48.

We were very conscious, as indeed we had been during the A-Station investigations, of sample disturbance, and its very significant effect on modulus values. Fig. 49 shows a plot of 
drained modulus against porosity for all the tests on the more argillaceous materials (A and B categories, and sub-categories) and a few tests on the C-materials (Table 7). Because of sample disturbance effects we adopted design values of $E$ corresponding to the line on Fig. 49 which is virtually an upper envelope of test values. A similar plot was attempted for the arenaceous materials (Categories C and D) but did not give a sensible result. Fig. 50 shows drained modulus values for these materials plotted against compressive strength. The selected modulus values are given in Table $8 ; E_{1}$ values are for 'undrained' modulus (10-minute loading cycle)

Table 8. Oldbury B: selected modulus values

\begin{tabular}{l|c|c|c|c}
\hline \multicolumn{1}{c|}{ Zone } & $\begin{array}{c}\text { Rock } \\
\text { category }\end{array}$ & $\begin{array}{c}E_{1} \\
\left(\mathrm{MN} / \mathrm{m}^{2}\right)^{*}\end{array}$ & $\begin{array}{c}E_{2} \\
\left(\mathrm{MN} / \mathrm{m}^{2}\right) \dagger\end{array}$ & $\begin{array}{c}E_{2} \\
E_{1}\end{array}$ \\
\cline { 2 - 4 } $\begin{array}{l}\text { Keuper Marl } \\
\text { Leached }\end{array}$ & $\begin{array}{l}\mathrm{WKM} \\
\mathrm{A}_{1} / \mathrm{A}_{2}\end{array}$ & - & 20 & - \\
& $\mathrm{A}_{2}$ & - & 40 & - \\
& $\mathrm{A}_{2} / \mathrm{B}$ & - & 100 & $(0.75)$ \\
& $\mathrm{B}$ & - & 200 & $(0.75)$ \\
Unleached & $\mathrm{C}$ & 1050 & 800 & 0.75 \\
& $\mathrm{D}$ & 1600 & 1400 & 0.9 \\
\multirow{4}{*}{ Basal conglomerate } & $\mathrm{B}$ & 1000 & 300 & $(0.75)$ \\
& $\mathrm{C}$ & 17000 & 12500 & 0.75 \\
& Fine & 2200 & 1700 & 0.75 \\
& Coarse & 18000 & 17000 & 0.95 \\
\hline
\end{tabular}

* $E_{1}$ from 10 minute cycle of loading-'undrained'

$\dagger E_{2}$ from 4 hour cycle of loading-'drained'

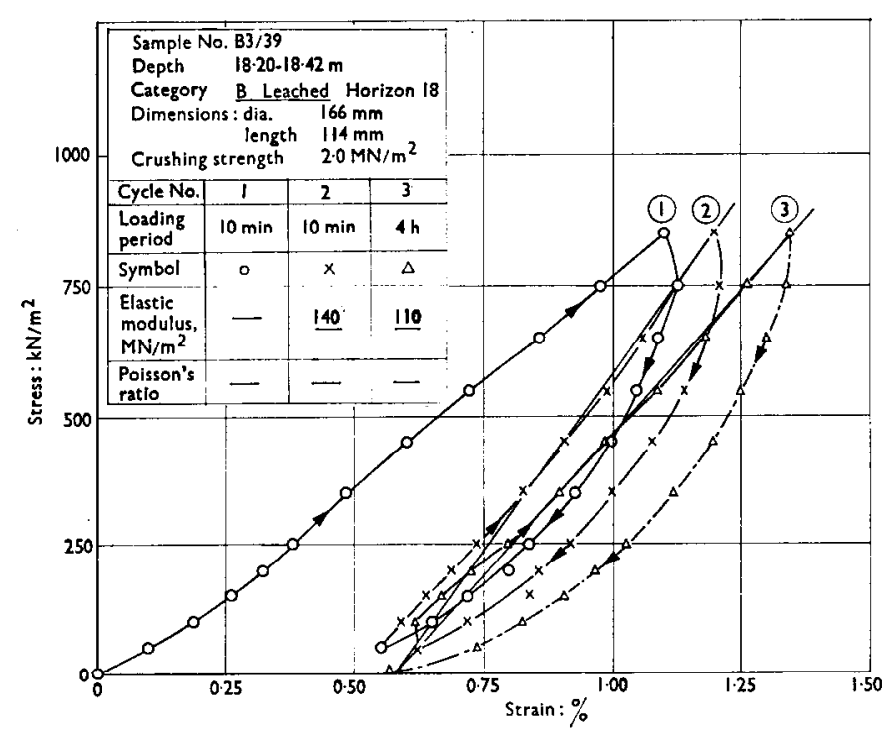

Fig. 46. Oldbury B: stress-strain curves, sample B3/39 
and $E_{2}$ values are for drained modulus. The selected modulus values cover a very wide range, as is also shown in Fig. 51 where they are plotted against depth, and in Fig. 52 which shows averages and ranges within the Keuper zones and in the Devonian.

It will be seen that it is not practicable to derive a linear modulus profile for the Oldbury rocks. The 'average' lines drawn on Fig. $51\left(E=190 \mathrm{MN} / \mathrm{m}^{2}\right.$ in the leached zone and $E=800 \mathrm{MN} / \mathrm{m}^{2}$ in the unleached zone) have been calculated from the relationship:

$$
\frac{z}{E}=\frac{z_{1}}{E_{1}}+\frac{z_{2}}{E_{2}}+\frac{z_{3}}{E_{3}}
$$

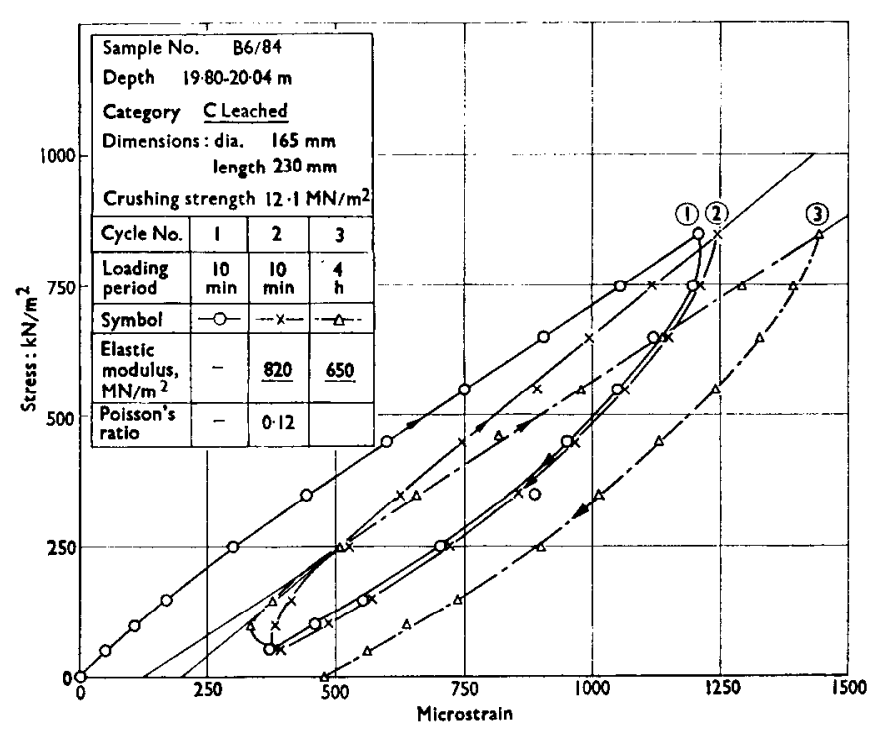

Fig. 47. Oldbury B: stress-strain curves, sample B6/84

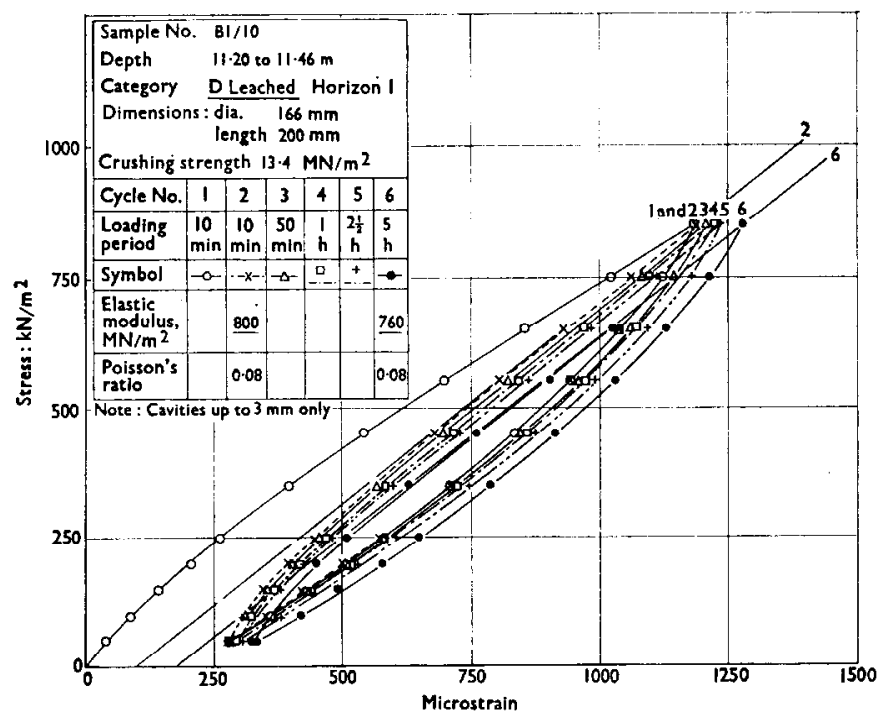

Fig. 48. Oldbury B: stress-strain curves, sample B1/10 
This has been done to give 'representative' values for the leached and unleached zones for comparative purposes only, and not for settlement calculation. A settlement calculation has been done, using the Olbury $B$ selected modulus values, and the foundation dimensions and loadings for the Oldbury A reactors (taking an average foundation level for $R_{1}$ and $R_{2}$ ). The

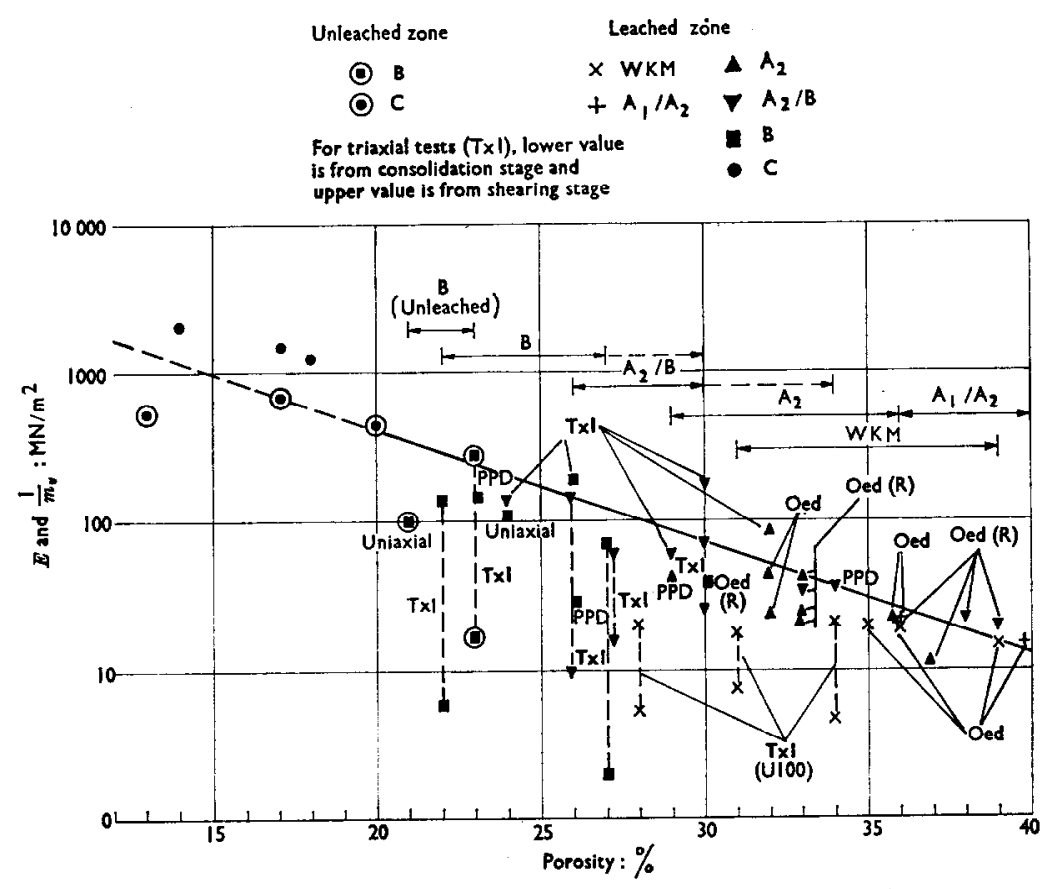

Fig. 49. Oldbury B: drained modulus against porosity (argillaceous materials)

Table 9. Oldbury A: summary of calculated pressure-ressel settlement (based on Oldbury B test data)

\begin{tabular}{|c|c|c|c|}
\hline Zone & Rock category & \multicolumn{2}{|c|}{$\begin{array}{c}\text { Settlement } \\
\text { component, } \mathrm{mm}\end{array}$} \\
\hline \multirow[t]{2}{*}{ Leached Keuper Marl } & $\begin{array}{c}\mathbf{A}_{1} / \mathbf{A}_{2}, \mathbf{A}_{2} \\
\mathbf{A}_{2} / \mathbf{B} \\
\mathbf{B} \\
\mathbf{C} \\
\mathbf{D}\end{array}$ & $\begin{array}{r}13 \\
21 \\
4 \\
5 \\
2\end{array}$ & \multirow{3}{*}{$\begin{array}{l}45 \\
13\end{array}$} \\
\hline & Heavily cavitated laycrs & 13 & \\
\hline Unleached Keuper Marl & $\begin{array}{c}\stackrel{\mathrm{A}_{2} / \mathrm{B}}{\mathrm{B}} \\
\mathrm{C} \\
\mathrm{D} \\
\text { Conglomerate }\end{array}$ & $\begin{array}{c}1 \\
1 \\
4 \\
\text { Negligible } \\
\text { Negligible }\end{array}$ & \\
\hline Devonian & & & 17 \\
\hline \multicolumn{3}{|c|}{ Total settlement (excluding creep) } & 81 \\
\hline
\end{tabular}


'spread-of-load' method has been used, assuming, arbitrarily, 1 in 2 spread in the leached zone (1 horizontal in 2 vertical), 1 in $1 \frac{1}{2}$ in the unleached zone and in the underlying Devonian rocks, and 1 in 1 in the basal conglomerate. $E$ values have been assigned to each individual horizon, on the basis of Table 8. The results of the calculation are shown in Table 9 . Of the $81 \mathrm{~mm}$ total calculated settlement (excluding creep) $45 \mathrm{~mm}$ is in the leached zone of the Keuper. This includes a $13 \mathrm{~mm}$ contribution from the heavily cavitated zones in the sandstones, based on the

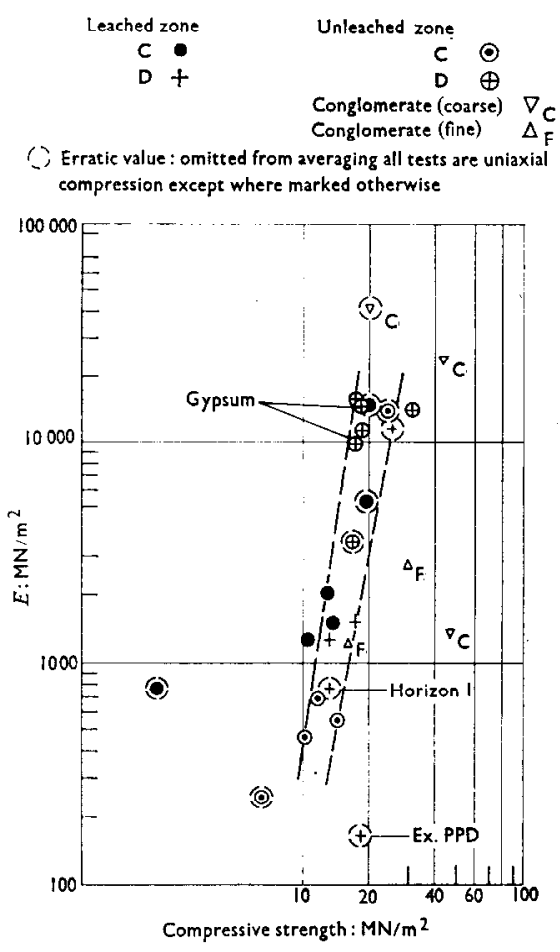

Fig. 50. Oldbury B: drained modulus against compressive strength

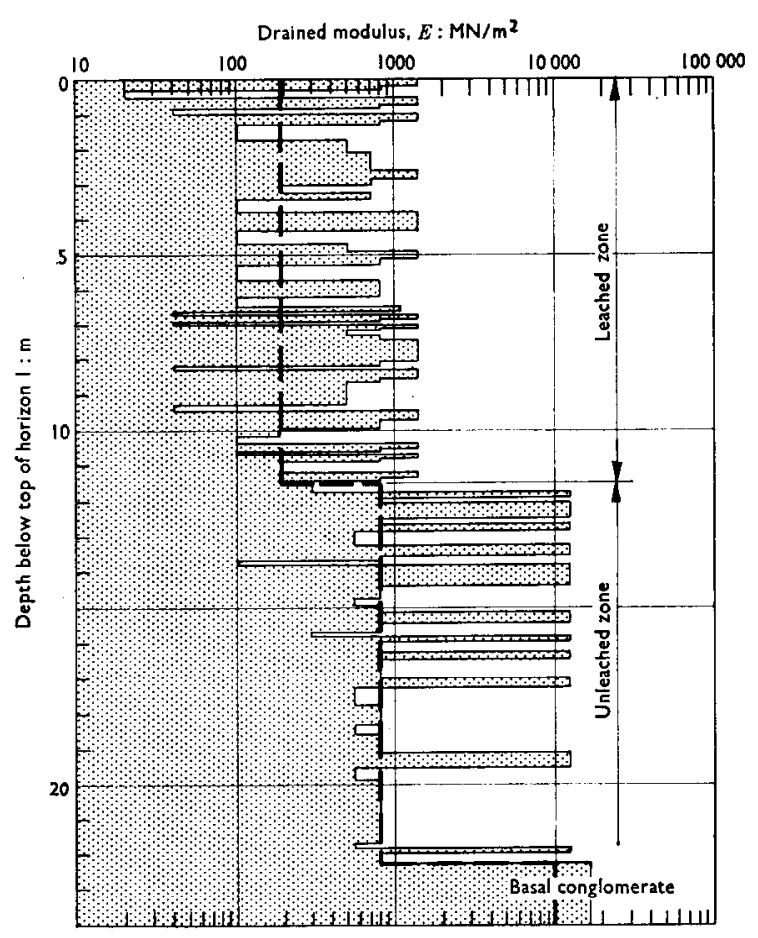

Fig. 51. Oldbury B: selected modulus values



Fig. 52. Oldbury B: selected modulus values, range and mean 


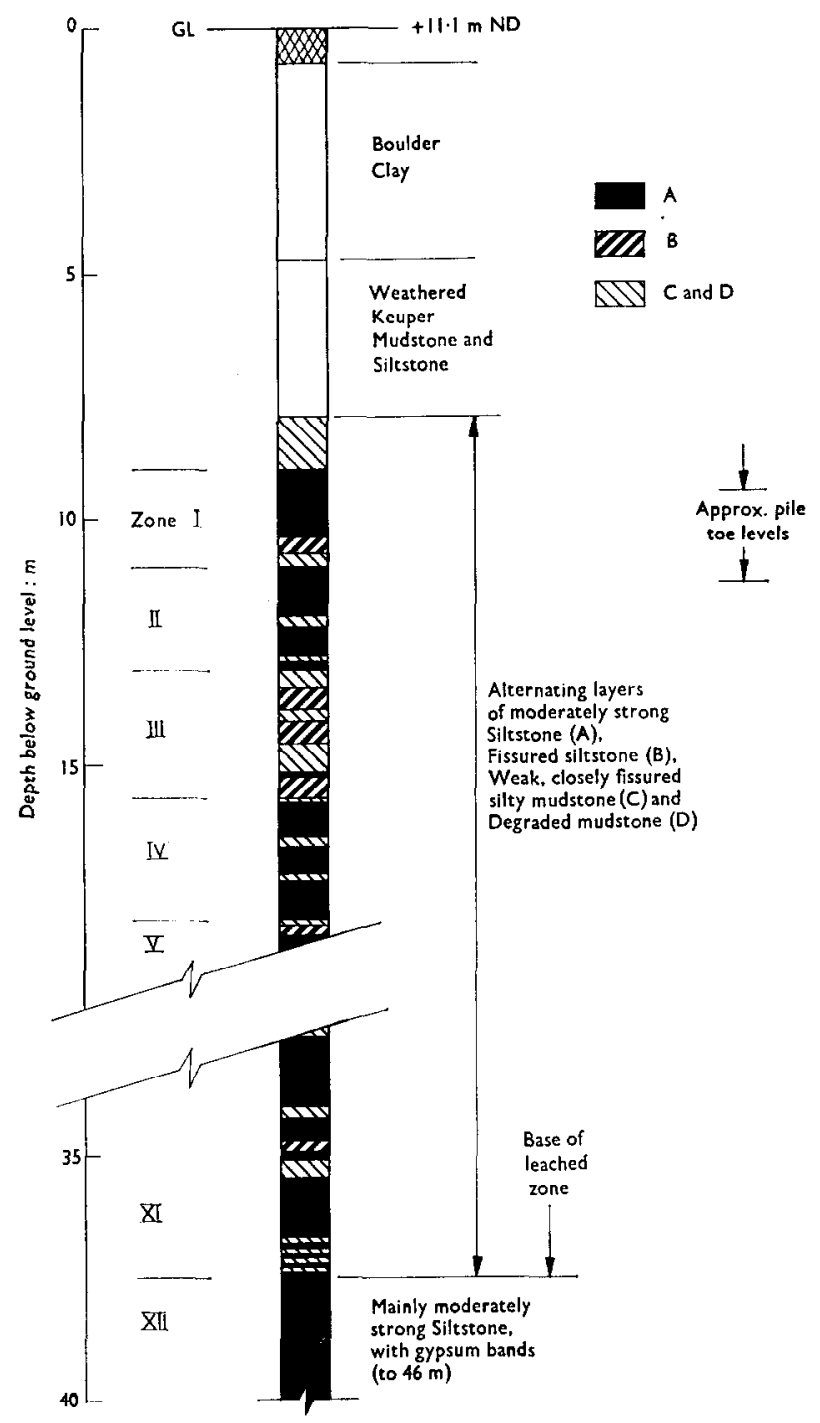

Fig. 53. Cardiff: simplified borehole log

A-Station plate loading tests. Only $6 \mathrm{~mm}$ of the total is in the unleached zone. The $17 \mathrm{~mm}$ in the Devonian is probably an over-estimate; the weaker Devonian materials were very difficult to sample and test, and considerable disturbance took place.

We also tested specimens in the laboratory to determine creep characteristics (Meigh et al., 1973). Based on the Oldbury B laboratory creep tests, the calculated creep over 30 years for the Oldbury A reactors would have been $33 \mathrm{~mm}$, of which $30 \mathrm{~mm}$ would be in the leached zone. From the load-time-settlement curves for Oldbury A, the actual creep will be in the range 30 to $45 \mathrm{~mm}$. So that on the face of it we can, using the Oldbury B test results, calculate for Oldbury A a total settlement of 110 to $125 \mathrm{~mm}$. This is to be compared with probable final settlements, including creep, of $105 \mathrm{~mm}$ for R1 and $125 \mathrm{~mm}$ for R2, average $115 \mathrm{~mm}$. A very good agreement one might say. However, there are several reservations to be made. 


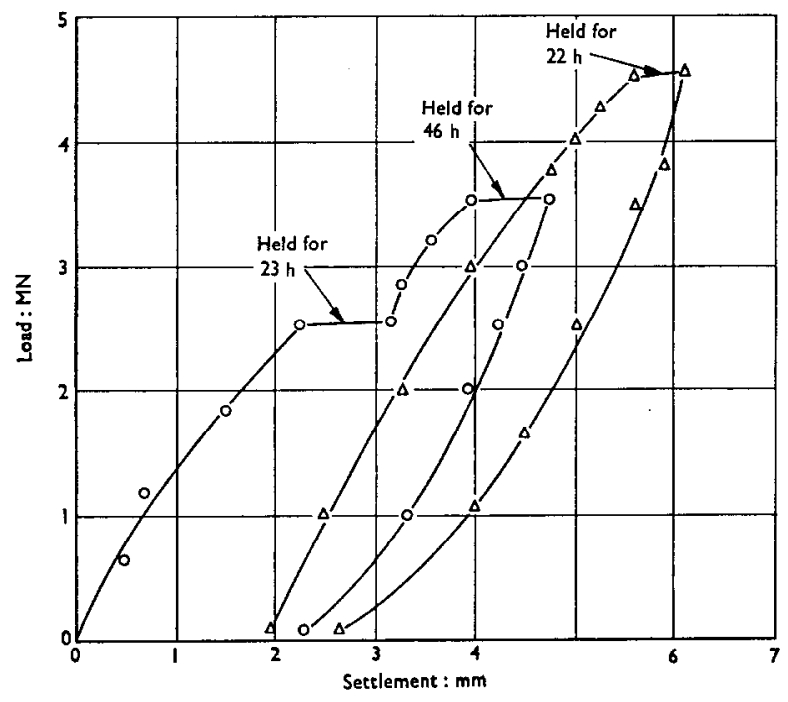

Fig. 54. Cardiff: pile loading test (pile diameter $=1070 \mathrm{~mm}$ )

(a) In spite of selecting $E$ values on the 'unsafe' side, they may still have been underestimated, because of the effects of sample disturbance, particularly in the weaker materials.

(b) No allowance has been made for the effects of joints and fissures, i.e. $j=1 \cdot 0$. The argument for this is that in the weaker siltstones, the fissures are at close centres and representative fissures will have been tested. Bedding joints were tight. It may well be that some allowance should have been made for the effects of joints in the sandstones. However, they had low values of Poisson's ratio (about $0 \cdot 1$ ) with near vertical jointing, and with fairly tight bedding. Allowing $j=0.5$ in the D-materials would have increased the calculated settlement by $2 \mathrm{~mm}$, and for C and D by $11 \mathrm{~mm}$.

(c) These calculations have been based on gross pressures, and hence some allowance has been made for recovery of heave (say $5 \mathrm{~mm}$ ). It is possible that excess waterpressures existed below foundation level during excavation down to that level. If this were so, then heave considerably greater than $5 \mathrm{~mm}$ would amost certainly have taken place. (The behaviour of the weaker siltstones in trial pile borings put down below the groundwater level in 1960-61 is clear evidence of this.)

It is hoped that the story of Olbury will have been of interest. It should at least have illustrated some of the complexities and difficulties of determining the deformation characteristics of Keuper Marl, where it occurs in such variety and in such close bedding.

\section{PEARL ASSURANCE HOUSE, CARDIFF}

The site of this office building is in the centre of Cardiff. It is marginal to the Bristol Channel Basin. Made ground and glacial drift overlie the upper part of the Keuper Marl which is here up to $150 \mathrm{~m}$ thick over the Dolomitic Conglomerate. A simplified log is shown in Fig. 53 from which it can be seen that there is cyclic pattern of deposition, each cycle a little over $2 \mathrm{~m}$ in thickness, and containing rocks in the following categories: (A) moderately 
strong siltstone; (B) partly fissured siltstone, less strong than (A); (C) weak, closely fissured silty mudstone; (D) mudstone degraded to a silt.

The rock is leached down to about $38 \mathrm{~m}$ below ground level, gypsum having been removed. Below this level there is gypsum in bands $10 \mathrm{~mm}$ or more thick, and the degraded mudstone (D) is absent.

The structure consists of a 24-storey tower block surrounded by a 4-storey 'podium'. The tower block is $27 \mathrm{~m}$ square in plan, with a total load of $350 \mathrm{MN}$, and a gross bearing pressure of $480 \mathrm{kN} / \mathrm{m}^{2}$. This is carried on bored piles, mostly of 1070 or $1220 \mathrm{~mm}$ diameter founded in the uppermost layer of moderately-strong Siltstone (A), 9 to $10 \mathrm{~m}$ below ground level, or where this was very thin, in the next such layer below. Bearing capacity of individual piles was not a problem, as indicated by the pile loading test result shown in Fig. 54.

Several drill-holes were put down using $137 \mathrm{~mm}$ diameter double-tube core barrels $(98 \mathrm{~mm}$ diameter core). However, in spite of careful drilling, core recovery was only $80-90 \%$. Modulus values for the stronger materials ((A) and (B)) were measured in the laboratory. For the weaker materials ((C) and (D)) satisfactory test specimens could not be obtained. Some pressuremeter tests were carried out with great difficulty in providing an undisturbed hole, particularly in the degraded mudstone (D), although there was some success using 'dry blocking'. Oedometer tests were done on some specimens of (D) material taken from the face of Llandough quarry some $3.6 \mathrm{~km}$ south-west of the site which was believed to be in the same stratigraphic horizon.

Settlement calculations were made, a conservative one giving a settlement of $76 \mathrm{~mm}$ and a more optimistic one giving a settlement of $38 \mathrm{~mm}$ (Table 10). The amount of settlement of the tower block was an important consideration because of differential settlement between it and the surrounding podium. The observed settlement of the tower block was only $15 \mathrm{~mm}$.

Recently the Llandough quarry, a disused brickworks now developed as a small industrial estate, was revisited and certain field work was carried out in an attempt to find an explanation for the very marked difference between observed and calculated settlement of the tower block. In the face of the quarry, Sully Beds (the Tea Green Marl), some $9 \mathrm{~m}$ thick, overlie the Keuper Marl, of which about $20 \mathrm{~m}$ is cxposed. The beds show remarkable continuity, and from green sandstone bands used as marker beds the dip was measured as $2^{\circ} 26^{\prime}$ to the north-east. The field work comprised the following:

Table 10. Cardiff : settlement assessment before construction

\begin{tabular}{c|r|r|r|r}
\hline \multirow{2}{*}{$\begin{array}{c}\text { Rock } \\
\text { category }\end{array}$} & \multicolumn{2}{|c|}{ First assessment } & \multicolumn{2}{c}{ Second assessment } \\
\cline { 2 - 5 } & $\begin{array}{r}E, \\
\mathrm{MN} / \mathrm{m}^{2}\end{array}$ & $\begin{array}{r}s, \\
\mathrm{~mm}\end{array}$ & $\begin{array}{r}E, \\
\mathrm{MN} / \mathrm{m}^{2}\end{array}$ & $\begin{array}{c}s, \\
\mathrm{~mm}\end{array}$ \\
\hline $\mathrm{A}$ & 1340 & 5 & 1600 & 4 \\
$\mathrm{~B}$ & 540 & 2 & 1070 & 1 \\
$\mathrm{D}$ & 72 & 16 & 86 & 13 \\
\hline Settlement & 15 & 53 & 43 & 20 \\
\hline \multicolumn{2}{l|}{} & 76 & & 38 \\
\hline
\end{tabular}

Note: More 'rounded' values were used, in imperial units 

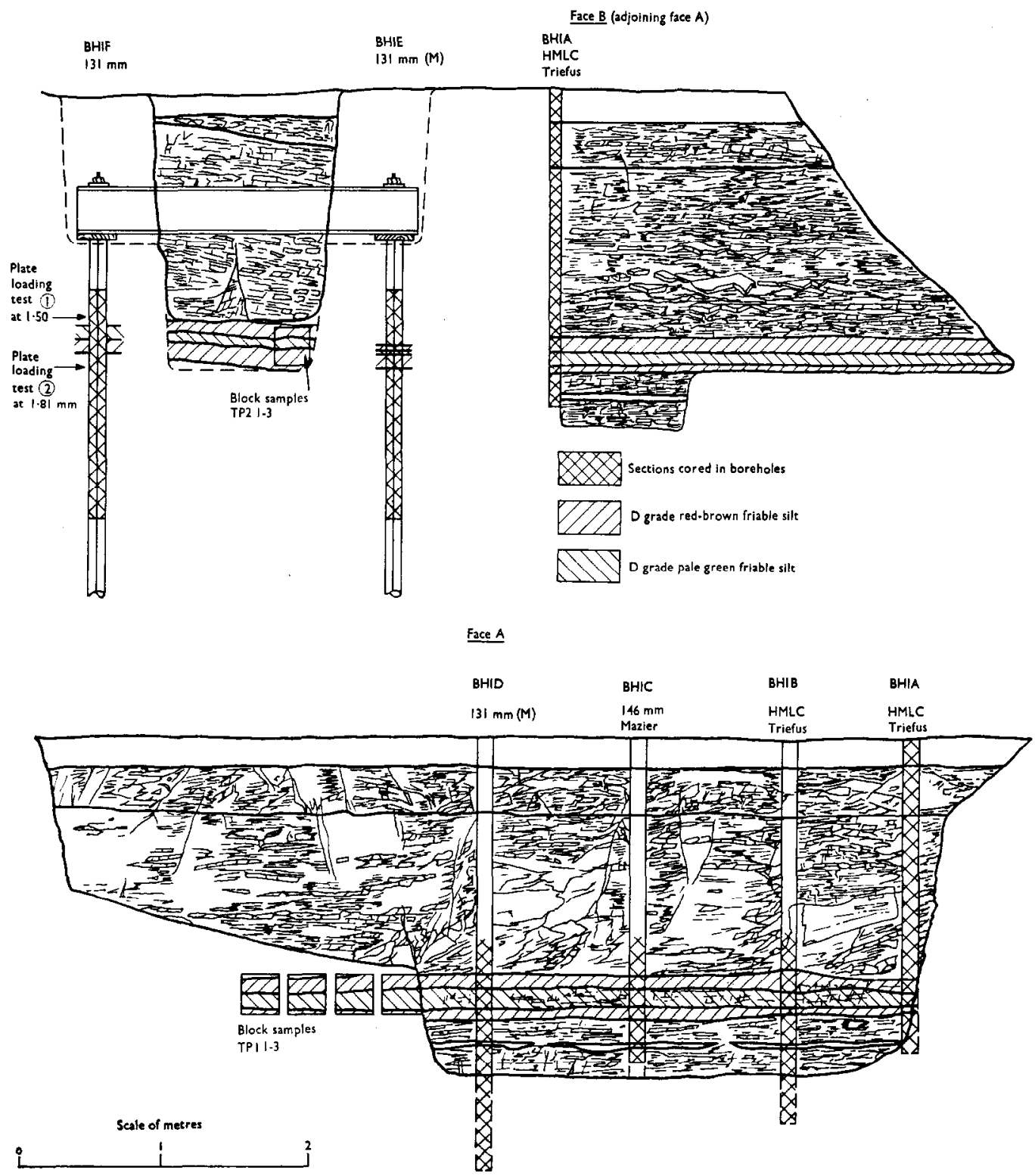

Fig. 55. Cardiff : sections through trial pit

(a) The trimming back and logging of a number of faces, in order to identify and examine in detail the various categories of rock, particularly the weaker materials C and D.

(b) A series of drill-holes using standard double-tube core barrels ( $98 \mathrm{~mm}$ core) and two makes of retractable triple-tube core-barrel, a Mazier barrel (105 mm diameter core) and a Treifus barrel (63 mm diameter core). With these triple-tube barrels, the middle tube is spring loaded, so that it leads the outer, rotating, cutting barrel in weak formations and retracts in stronger formations. 
(c) A trial pit excavated below a bench in the quarry, with its back face intersecting a number of the drill-holes (Fig. 55).

(d) Two plate loading tests in a lateral extension of the trial pit, one on a $300 \mathrm{~mm}$ thick layer of (D) material, and the other on the mixed (B) and (C) materials immediately below (Fig. 55).

Detailed examination of sections of the quarry face and of the trial pit faces confirmed a succession very similar to that found at the Pearl Assurance House site. In spite of the remarkable continuity of beds there is intense local variation with abrupt changes between one rock category and another. The beds of moderately strong siltstone (A) are fairly massive (Fig. 56(a)). Joints in this material are tight, and fissuring is less than indicated by drill cores. With stress relief and weathering, incipient fissures open up with a progressive reduction in the sizes of rock pieces. However, the pieces remain moderately strong, and angular, down to sizes of a few millimetres. This can be seen in Fig. 56(d), showing scree material. The partly fissured siltstone (B) is more closely bedded, and only moderately weak to moderately strong, but is otherwise similar to (A).

The weak closely fissured silty mudstone (C) can be seen in the upper part of Fig. 56(c). The fissures are tight in situ, but are easily separated by weathering, the rock reducing to a silty clay. The degraded mudstone (D) is mainly an orange coloured structureless silt. (The flat surfaces in Fig. 56(b) are knife marked.) It occurs in association with bands of green siltstone which are themselves degraded in places (Fig. 56(a) and (b)). Three principal horizons of degraded rock were found, with thicknesses, including the green degraded material, ranging from $300 \mathrm{~mm}$ to $500 \mathrm{~mm}$. Degraded mudstone also occurs in small pockets.

The drill-holes intersected by the trial pit gave markedly different results, only about $80 \%$ recovery being obtained with the $131 \mathrm{~mm}$ double-tube barrel, but $100 \%$ with the Treifus and Mazier barrels. Furthermore, the quality of core recovered was very much better with these two barrels than with the standard double-tube barrel. A second series of somewhat deeper holes, up to about $6 \mathrm{~m}$ depth, gave similar results. Finally, a deeper hole from a higher bench in the quarry was put down to a depth of $13.3 \mathrm{~m}$ using the Mazier retractable triple-tube core barrel. This gave $99 \%$ recovery of high quality core, the $100 \mathrm{~mm}$ lost being at the end of a run.

The values of drained modulus, $E$, used in the preconstruction settlement calculations are given in Table 10, together with the components of calculated settlement for each category of rock. It can be seen that the stronger materials (A) and (B) make no appreciable contribution to settlement, which is mainly centred in (C) and (D). The modulus values for (D) material in the 'first assessment' in Table 10 were based on the oedometer tests on specimens taken from the quarry face during the site investigation. Those in the 'second assessment' were based on the pressuremeter results. The plate loading test on (D) material in the subsequent investigation of the quarry gave $E=40 \mathrm{MN} / \mathrm{m}^{2}$, almost the same value as used in the 'second assessment'. Laboratory tests, triaxial and oedometer, gave results only about half this value. The second plate loading test gave $E=300 \mathrm{MN} / \mathrm{m}^{2}$, but this was on interbedded (B) and (C) materials, suggesting a value of about $200 \mathrm{MN} / \mathrm{m}^{2}$ for (C) material, more than double the value used in the 'second assessment'. Taking account of this higher $E$ value would reduce the calculated settlement to about $31 \mathrm{~mm}$, which is still twice the observed settlement.

A further factor arises from the attribution of lost core, which is detailed in Table 11. It is seen that of the $20.4 \%$ of core lost, $7.5 \%$ has been attributcd to (C) matcrial and $6.8 \%$ to (D) material. Any alteration of these figures can be done only on a speculative basis, although some guidance, which may not be relevant, can be taken from the deep drill-hole in the quarry. Such speculation might reduce the calculated settlement to about $23 \mathrm{~mm}$ compared with the 

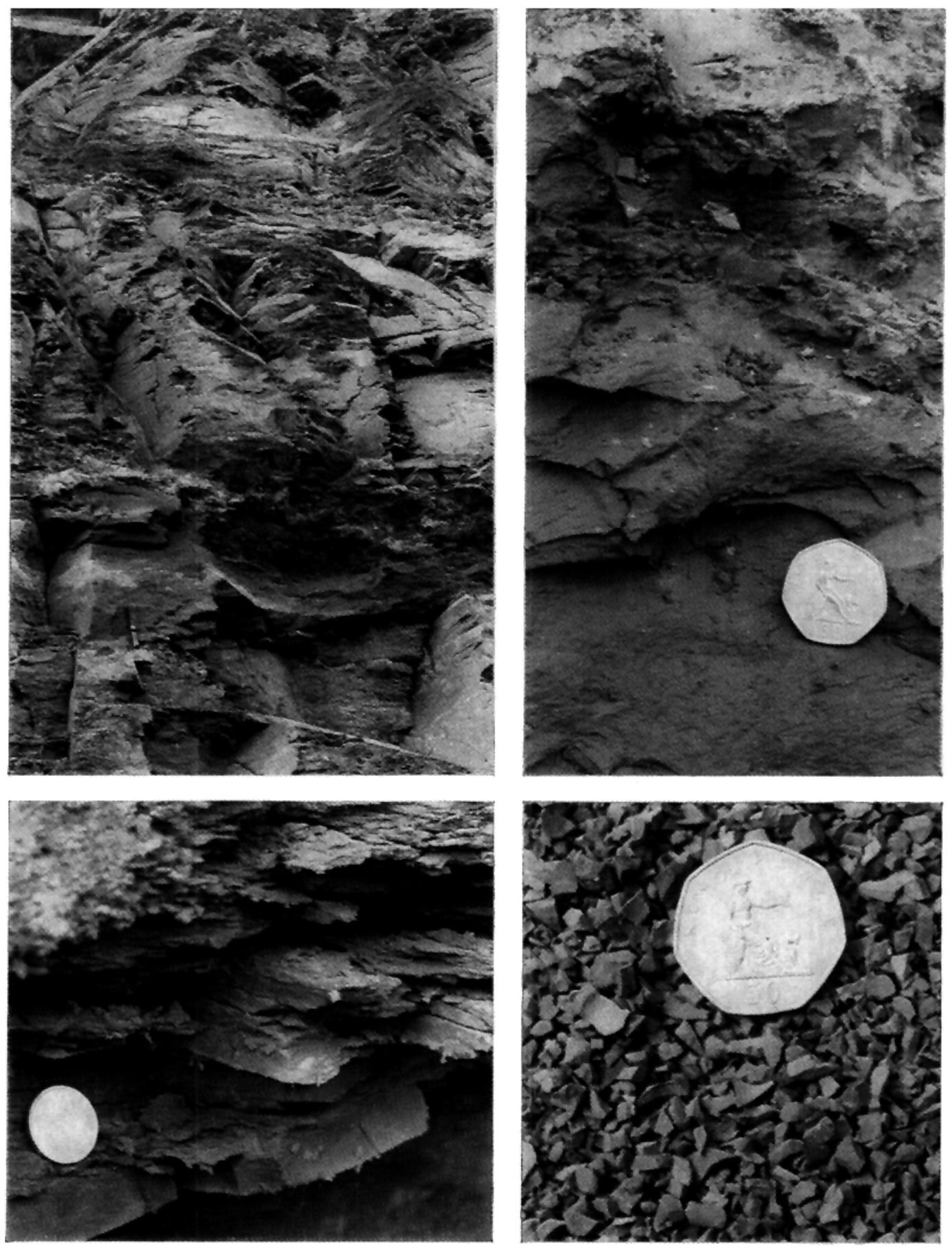

Fig. 56. Keuper Marl in Llandough Quarry, near Cardiff: (a, top left) general view of quarry face; (b, top right) degraded mudstone (D); (c, bottom left) weak, closely fissured silty mudstone (C) in upper part; (d, bottom right) scree fragments of moderately strong siltstone 
observed settlement of $15 \mathrm{~mm}$, requiring a further reduction of $35 \%$ to achieve correspondence between observed and calculated settlement. This could possibly be found from a number of factors involed in the computation, in which greater precision may be justified in view of the reduced uncertainty about modulus values:

(a) In the 'spread-of-load' settlement calculation, $m_{\mathrm{v}}$ was taken conservatively as $1 / E$, whereas with $\nu=0.2$, it would be appropriate to use $0.9 / m_{\mathrm{v}}$, thus reducing calculated settlement by $10 \%$;

(b) Spread-of-load was taken at 0.5 in $1 ; 0.6$ in 1 might be better, reducing calculated settlement by $10 \%$;

(c) The correction for 'rough base' to foundation, $F_{B}$, based on Popova's work (Fig. 7) would give an $8 \%$ reduction.

The adjustments above total $28 \%$. Alternatively, since this is a strongly layered system, a Westergaard stress distribution may be preferable to that given by the spread-of-load calculation which approximates a Boussinesq distribution. This would reduce calculated settlement by $25 \%$.

\section{CONCLUSIONS}

In the first part of this lecture some profiles of drained modulus of elasticity $E$ were presented, which are summarized in Fig. 26, showing marked differences between the Birmingham mudstone (in the lower part of the Keuper Marl, in the western part of the Birmingham Basin) and the siltstones in Lincolnshire (in the western part of the North Sea Basin). Intermediate values of $K_{z}$, the rate of increase of modulus with depth, were found in the marginal facies adjacent to the Charnwood Sill at the M1 bridge sites near Loughborough, and in the leached zone of the siltstones at Hams Hall (in the Birmingham Basin, but at a higher level in the Keuper than the Birmingham area).

At Portskewett, in Keuper Marl, but in a more arenaceous zone, considerably higher modulus values were found.

Brief mention was made of modulus values in the Bunter, which appears to be less variable than the Keuper.

From the lecture as a whole, attention is drawn to the following.

Case histories cannot realistically be analysed on the basis of a constant modulus and infinite depth of foundation material.

A knowledge of the broad geological structure of our site, its depositional environment, should provide a preliminary indication of the lithology to be expected, and hence, within

Table 11. Cardiff: Core recovered and core lost, borehole $F-$ zones II-IX

\begin{tabular}{c|c|c|c|c|c|c}
\hline \multirow{2}{*}{$\begin{array}{c}\text { Rock } \\
\text { category }\end{array}$} & \multicolumn{2}{|c|}{ Core recovered } & \multicolumn{2}{c|}{$\begin{array}{c}\text { Lost core } \\
\text { attributed }\end{array}$} & \multicolumn{3}{c}{ Total } \\
\cline { 2 - 7 } & $\mathrm{m}$ & $\%$ & $\mathrm{~m}$ & $\%$ & $\mathrm{~m}$ & $\%$ \\
\hline A & 8.86 & 41.1 & 0.21 & 1.0 & 9.07 & 42.1 \\
B & 3.35 & 15.5 & 1.09 & 5.1 & 4.44 & 20.6 \\
C & 2.87 & 13.3 & 1.62 & 7.5 & 4.49 & 20.8 \\
D & 2.10 & 9.7 & 1.47 & 6.8 & 3.57 & 16.5 \\
\hline Total & 17.18 & 79.6 & 4.39 & 20.4 & 21.57 & 100.0 \\
\hline
\end{tabular}


broad limits, the modulus profile below the weathered zone. In some areas, however, modulus values may have been reduced by leaching.

The weaker materials in a mixed succession, which naturally contribute most to settlement, are the most susceptible to disturbance and the most difficult to core. It is vitally important to obtain $100 \%$ core recovery; triple-tube retractor-type core barrels make this a practical possibility. Sample disturbance and stress relief have dominant effects on laboratory test results (and on field test results). When basing design values on laboratory test results, there is some justification for taking design values of modulus on the 'unsafe' side if realistic estimates of settlement are to be made. In estimating the mass factor, $j$ (ratio of field to laboratory modulus), care should be taken not to over-estimate the degree of fissuring; this can be falsified by the action of drilling.

It is suggested that all important site investigations of the Triassic rocks should begin with one or two careful drill-holes, using retractable-type core barrels and protecting the cores against drying; that all those concerned with the planning, execution and interpretation of the investigation should be assembled when these cores are being logged and should take part in a detailed examination of the core, pulling it apart and taking specimens for determination of water content, carbonate, and so on, unhindered by the usual restraint of having to preserve some parts of the core for testing. This examination should make it possible to identify the problem materials and to plan properly a programme of drilling, pitting and the associated laboratory and in situ testing.

Looking to the future, further knowledge and understanding of the engineering properties of the Triassic rocks would result from more measurement of water content and carbonate content, differentiating where practicable between calcium carbonate and dolomite, and from inspection of thin sections in the hope of identifying cementing agents. This information should be related both to $E$ values (and to other properties) and to the lithology, taking the depositional environment into account.

Terzaghi emphasized the need for case histories and suggested that "laboratory investigations should not receive too much attention unless the validity of the conclusions has been demonstrated by adequate field observations on full-sized structures'. I do not disagree but I will suggest a rider, in relation to rocks such as the Trias, particularly the Keuper. Terzaghi was, I feel sure, referring to soils. The rider is this: given these field observations on full-sized structures, we need to look very closely at the structure of the rock mass, and at our field and laboratory test results, and to understand the limitations of those results, particularly those from the laboratory, before we can fully utilize our case histories.

I hope that from what I have said, it will at least be clear that the Triassic rocks do vary considerably from place to place, from one depositional environment to another. Not all Keuper Marl is Birmingham mudstone.

\section{ACKNOWLEDGEMENTS}

I acknowledge with gratitude the help of many colleagues, particularly Peter Jordan, Noel Hobbs and Richard Haydon. Most of the investigations referred to were done for the Central Electricity Generating Board, either directly or through their Consulting Engineers, and I am grateful to the CEGB for permission to make such reference; also to The Nuclear Power Group for the agreement to my discussing the problems at Oldbury; to A. E. Beer and Partners for permission to refer to the Pearl Assurance House investigations, and for providing the settlement data; to W.S. Atkins and Partners for permission to refer to the Redcar data; to the Runcorn Development Corporation for permission to refer to the Runcorn test results; 
and to Dr A. G. Davis, Dr M. J. Chandler and to Mr S. H. Rogers of Sir Owen Williams and Partners for information on the M1 bridges. Rush and Tompkins Limited kindly allowed access to the Llandough quarry.

\section{REFERENCES}

Audley-Charles, M. A. (1970). Stratigraphical correlation of the Triassic rocks of the British Isles. Q. Jnl Geol. Soc. London 126, 19-47.

Burland, J. (1970). Discussion on Session A. In-situ investigations in soils and rocks. London: British Geotechnical Society.

Butler, F. G. (1974). Heavily over-consolidated clays. Review paper, Session III. Conf. on Settlement of Structures, Cambridge. London: Pentech Press.

Chandler, R. J. (1969). The effect of weathering on the shear strength properties of Keuper Marl. Géotechnique 19 , No. 3, 321-334.

Davis, A. G. (1967). Keuper Marl research summary. (Prepared by N. Birch, R. J. Chandler, A. G. Davis and C. S. Dunn, under the direction of Professor J. Kolbuszewski, University of Birmingham, for CIRIA.)

Davis, A. G. (1970). The analysis of the observed settlement of a multi-storey block of flats at Highgate, Birmingham. Research Report to CIRIA, Nov. 1970.

Davis, A. G. \& Chandler, R. J. (1973). Further work on the engineering properties of Keuper Marl. CIRIA Report 47.

Fox, E. N. (1948). The mean elastic settlement of a uniformly loaded area at a depth below the ground surface. Proc. 2nd Int. Conf. Soil Mech. Fdn Engng, Rotterdam 1, 129.

Hobbs, N. B. (1973). Effects of non-linearity on the prediction of settlements of foundations on rock. Q. Jnl Engng Geol. 6, No. 2, 153-168.

Hobbs, N. B. (1975). The factors affecting the prediction of the settlement of structures on rock. Review paper, Session IV. Conf. on Settlement of Structures, Cambridge. London: Pentech Press.

Meigh, A. C. \& Greenland, S. W. (1965). In-situ testing of soft rocks. Proc. 6th Int. Conf. Soil Mech. Fdn Engng, Montreal 1, 73-76.

Meigh, A. C., Skipp, B. O. \& Hobbs, N. B. (1973). Field and laboratory creep tests on weak rocks. Proc. 8th Int. Conf. Soil Mech. Fdn Engng, Moscow 1.2, 265-271.

Ménard, L. (1957). Mesures in-situ des propriétés physiques des sols. Annls ponts chauss. $\left(127^{\circ}\right.$ année) 3, 358.

Ménard, L. (1965). Règles pour le caloul de la force portante et du tassement des fondations en fonction des résultats pressiométriques. Proc. 6th Int. Conf. Soil Mech. Fdn Engng, Montreal 2, 295-299.

Popova, O. V. (1972). Stress and displacement distributions in a homogeneous half-space below a circular foundation. Translation from Osnov. Fundam. Mech. Grunt. 2, 10-12, Mar.-Apr., by Consultants Bureau. New York: Plenum Publishing Corporation.

Rhys, G. H. (1974). A proposed standard lithostratigraphic nomenclature for the Southern North Sea and an outline structural nomenclature for the whole of the (UK) North Sea. Report of the Joint Oil IndustryIGS Committee on North Sea nomenclature. Rep. Inst. Geol. Sci. No. 74/8.

Steinbrenner, W. (1934). Tafeln zur Setzungsberechnung. Die Strasse 1, 121-124.

Terzaghi, K. (1943). Theoretical soil mechanics, p. 425. New York: John Wiley.

Terzaghi, K. (1948). Foreword. Géotechnique 1, No. 1, 3-5.

Ueshita, K. \& Meyerhof, G. G. (1968). Surface displacement of an elastic layer under uniformly distributed loads. Highw. Res. Board Record, No. 228.

Ziegler, W. H. (1975). Outline of the geological history of the North Sea. Petroleum and the continental shelf of north-west Europe 1, Geology, 165-187. Ed. A. W. Woodland. Barking Essex: Applied Science Publishers.

\section{VOTE OF THANKS}

Mr Little proposed a vote of thanks. In the UK geotechnics is essentially a practical subject. Although some institutions are undertaking fundamental research, the majority are more concerned with engineering applications. It is therefore particularly appropriate that tonight we have had a lecture from a practising engineer who leads one of the most successful specialist contracting firms in the country. Dr Alan Meigh has given us the sort of address that we would have expected from him and which is a worthy successor to the previous fifteen Rankine Lectures. This lecture is so packed with information that it will become and remain a quarry (a metaphor that seems peculiarly appropriate) for engineers and engineering geologists, immediately and for a long time to come. As well as this, he has corrected some wrong 
impressions. Those needing information on the properties of the Triassic rocks will first turn to Dr Mcigh's lecture and they should not be disappointed with what they find there.

We are doubly fortunate to have had this address from someone of his experience and ability. The soft rocks which are typical of the Trias occupy a no man's land, a sort of twilight zone, between soils and hard rocks which are respectively the domains of the soil mechanics expert and the hard rock geologist. Quantitative information on soft rocks has been notably lacking by comparison with either of the other two categories but that situation has now been largely corrected.

We should perhaps spare a thought for those behind the scenes who have helped with this massive assemblage of data (and whom Dr Meigh has already acknowledged) but our principal thanks must be to Dr Meigh, not only for his hard work in assembling and presenting the facts to us but also for the generous way in which he has made exclusive information available to us and for his courage in confessing to errors of interpretation and forecast with which he has been concerned and offering a corrected analysis.

I hope that you will join with me in a hearty vote of thanks to him.

The vote of thanks was accorded with acclamation 